\title{
SIMULATION OF GROUND-WATER FLOW IN THE UNCONFINED AQUIFER SYSTEM OF THE TOMS RIVER, METEDECONK RIVER, AND KETTLE CREEK BASINS, NEW JERSEY
}

by Robert S. Nicholson and Martha K. Watt

U.S. GEOLOGICAL SURVEY

Water-Resources Investigations Report 97-4066

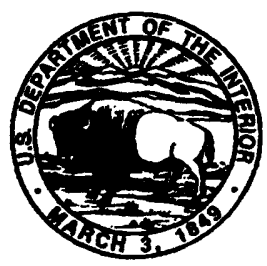

Prepared in cooperation with the NEW JERSEY DEPARTMENT OF ENVIRONMENTAL PROTECTION

West Trenton, New Jersey 


\title{
U.S. DEPARTMENT OF THE INTERIOR \\ BRUCE BABBITT, Secretary
}

\author{
U.S. GEOLOGICAL SURVEY \\ Gordon Eaton, Director
}

For additional information write to:

District Chief

U.S. Geological Survey

Mountain View Office Park

810 Bear Tavem Road, Suite 206

West Trenton, NJ 08628
Copies of this report can be purchased from:

U.S. Geological Survey

Branch of Information Services

Box 25286

Denver, CO 80225-0286

To request numerical model input data sets in electronic form, contact the Information Officer, U.S. Geological Survey, New Jersey District, at the above address, or call (609) 771-3900. 


\section{CONTENTS}

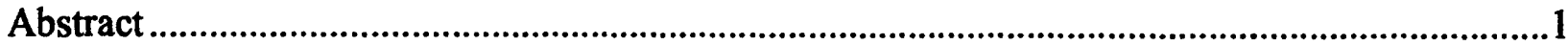

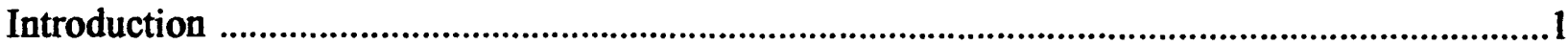

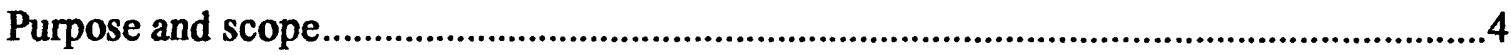

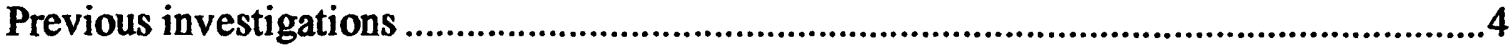

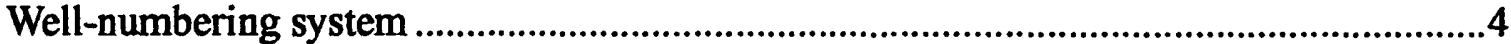

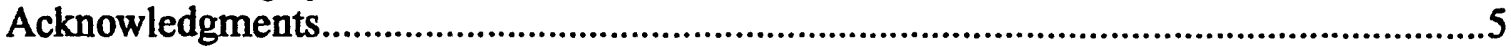

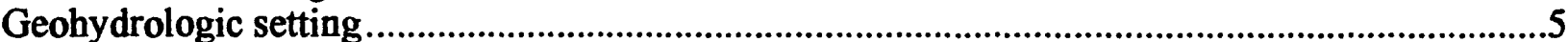

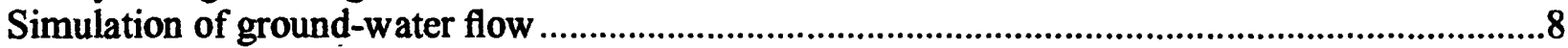

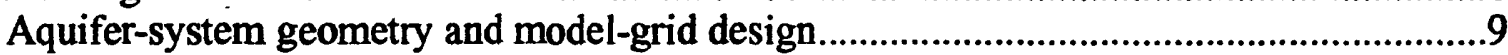

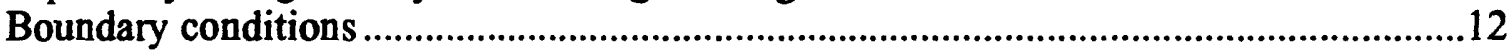

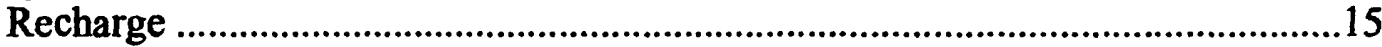

Ground-water evapotranspiration .....................................................................17

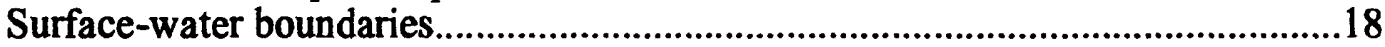

Hydraulic properties of aquifers and confining units..................................................18

Kirkwood-Cohansey aquifer system .....................................................................18

Basal Kirkwood Formation confining unit ...........................................................24

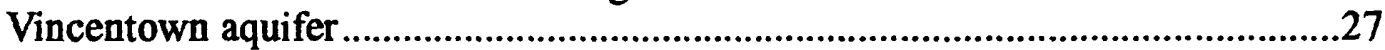

Composite confining unit.......................................................................................27

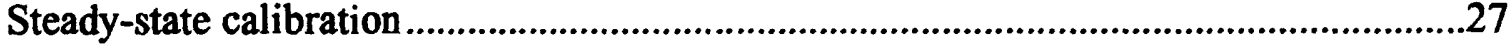

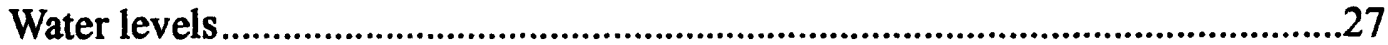

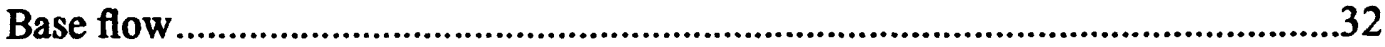

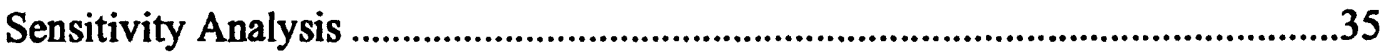

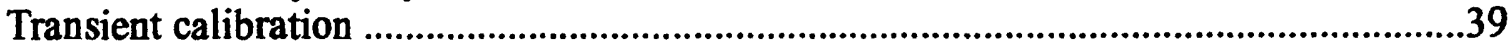

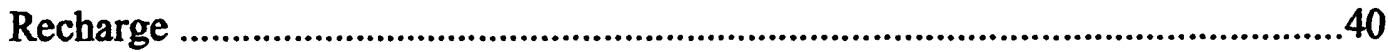

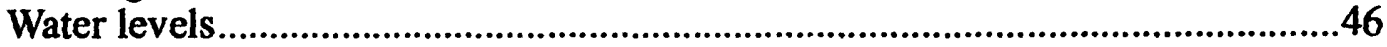

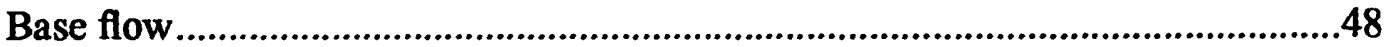

Sensitivity Analysis .............................................................................................5

Ground-water flow under predevelopment and recent condtitions.................................................51

Predevelopment conditions ....................................................................................................51

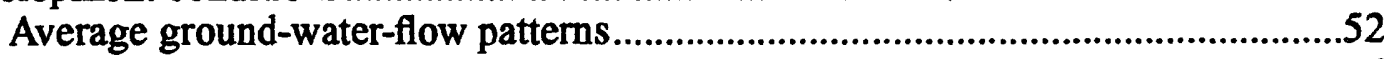

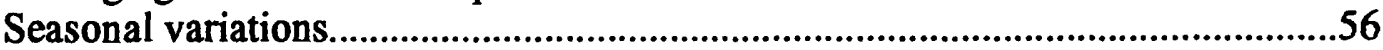

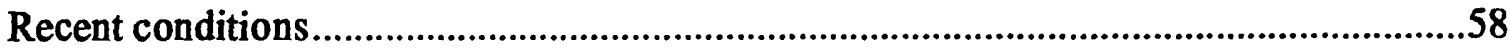

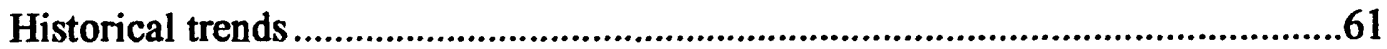

Average ground-water-flow patterns...................................................................63

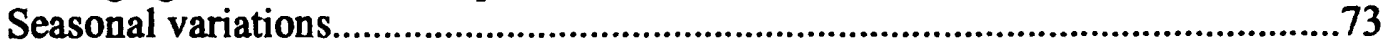

Uncertainty in predicted effects of withdrawals .....................................................77

Simulated effects of additional ground-water withdrawals .........................................................81

Limitations of predictive simulations .............................................................................8

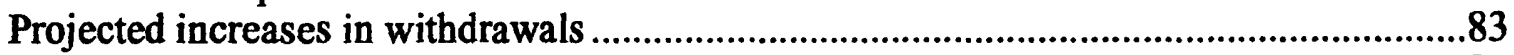

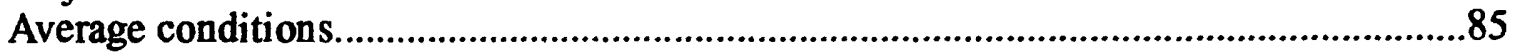

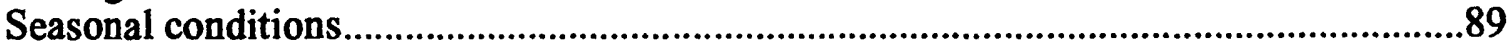

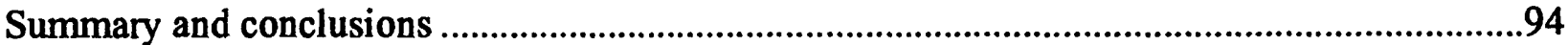

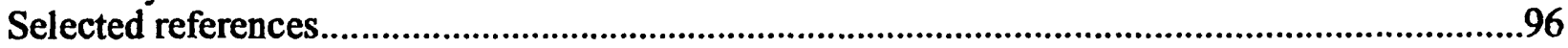

Appendix. Well-construction data for observation wells in the Kirkwood-Cohansey aquifer

system located in or near the Toms River, Metedeconk River, and Kettle Creek Basins,

New Jersey 


\section{ILLUSTRATIONS}

Page

Figure 1. Map showing location of study area in the New Jersey Coastal Plain ......................2

2. Map showing location of model area, streamflow-gaging stations, low-flow stations, observation wells, and weather stations, Toms River, Metedeconk River, and Kettle Creek Basins, New Jersey

3. Generalized hydrogeologic section through the study area, Toms River, Metedeconk River, and Kettle Creek Basins, New Jersey.

4. Diagram showing schematic representation of the ground-water-flow system, Toms River, Metedeconk River, and Kettle Creek Basins, New Jersey

5. Map showing structure contours of the base of the Kirkwood-Cohansey aquifer system, Toms River, Metedeconk River, and Kettle Creek Basins, New Jersey

6. Diagrammatic section showing relation between aquifer units and model layers in the ground-water-flow model, Toms River, Metedeconk River, and Kettle Creek Basins, New Jersey.

7. Map showing model grid, lateral boundaries, and internal boundaries representing surface-water features, Toms River, Metedeconk River, and Kettle Creek Basins, New Jersey .

8. Map showing wetland and urban areas in the Toms River, Metedeconk River, and Kettle Creek Basins, New Jersey

9. Map showing locations of wells used to determine hydraulic conductivity from well-performance data, Toms River, Metedeconk River, and Kettle Creek Basins, New Jersey

10. Map showing the distribution of horizontal hydraulic conductivity and specific yield, model layer 1, Toms River, Metedeconk River, and Kettle Creek Basins, New Jersey

11. Map showing distribution of vertical leakance between model layers 1 and 2 and distribution of horizontal hydraulic conductivity in model layer 2, Toms River, Metedeconk River, and Kettle Creek Basins, New Jersey....

12. Map showing distribution of vertical leakance between model layer 2 and underlying aquifers, Toms River, Metedeconk River, and Kettle Creek Basins, New Jersey

13. Map showing locations of wells used in steady-state-model calibration, Toms River, Metedeconk River, and Kettle Creek Basins, New Jersey

14. Map showing observed and simulated water-table altitudes, Toms River, Metedeconk River, and Kettle Creek Basins, New Jersey.

15. Graph showing relation between measured (October-November 1987) and simulated average (1980-89) water levels, model layers 1 and 2, Toms River, Metedeconk River, and Kettle Creek Basins, New Jersey.

16. Graph showing transverse water-table profiles along model column 36 simulated by using calibrated values of layer 1 horizontal hydraulic conductivity and values of layer 1 horizontal hydraulic conductivity multiplied by factors of 0.2 and 2, Toms River, Metedeconk River, and Kettle Creek Basins, New Jersey ..36 


\section{ILLUSTRATIONS--continued}

Page

Figure 17. Graph showing recharge, ground-water withdrawals, and ground-water evapotranspiration as represented in simulation of transient conditions, June 1992-May 1993, Toms River, Metedeconk River, and Kettle Creek Basins, New Jersey .

18. Hydrographs of measured water-level changes (relative to initial values) in wells 25-716, 29-1056, 29-1059, and 29-1060, and daily precipitation at the Toms River, N.J., weather station, May-August 1992

19. Graphs showing (a) average total monthly precipitation at Toms River, Hightstown, and Pemberton, N.J., weather stations, and monthly recharge estimated from streamflow data by Rorabaugh (1964) method, by monthly water-budget method, and by adjusted daily water-budget method, June 1992-May 1993; and (b) hydrographs of water levels in well 29-1060 and monthly base flow of Toms River near Toms River, N.J., streamflow-gaging station (01408500), June 1992-May 1993

20. Graphs showing observed and simulated water-level changes in four observation wells, June 1992-May 1993, Toms River, Metedeconk River, and Kettle Creek Basins, New Jersey.

21. Observed and simulated average monthly base flow of the (a) Toms River near Toms River, N.J. (01408500), and (b) North Branch Metedeconk River near Lakehurst, N.J. (01408120)

22. Map showing simulated water levels and flow directions in model layer 1 under predevelopment conditions, Toms River, Metedeconk River, and Kettle Creek Basins, New Jersey.

23. Map showing vertical flow directions across bottom of model layer 1 under predevelopment conditions, Toms River, Metedeconk River, and Kettle Creek Basins, New Jersey

24. Map showing vertical flow directions across bottom of model layer 2 under predevelopment conditions, Toms River, Metedeconk River, and Kettle Creek Basins, New Jersey

25. Map showing simulated ground-water basins and surface-water divides under predevelopment conditions, Toms River, Metedeconk River, and Kettle Creek Basins, New Jersey

26. Graphs showing (a) average monthly recharge; (b) simulated predevelopment base flow of the Toms River during a typical annual cycle; (c) water levels at model node (layer, row, column) $=(1,26,15)$ near the headwaters of Ridgeway Branch tributary to the Toms River; and (d) water levels at model node (layer, row, column) $=(1,24,12)$ near the topographic high between the Toms River and Crosswicks Creek, N.J

27. Graph showing typical ground-water budgets for the Toms River Basin, N.J., March and October, under predevelopment conditions

28. Graph showing base flow of the Toms River, N.J., as a percentage of total flow, 1932-90 


\section{ILLUSTRATIONS--continued}

Page

Figure 29. Hydrographs showing water levels in observation wells 5-689 and 29-486, and the relation between observed and statistically predicted water levels in observation well 29-486, Toms River, Metedeconk River, and Kettle Creek Basins, New Jersey

30. Map showing average recent (1989-92) pumpage of wells tapping the KirkwoodCohansey aquifer system in Toms River, Metedeconk River, and Kettle Creek Basins, New Jersey.

31. Map showing simulated water-level changes in model layer 1 and base-flow reduction from predevelopment conditions due to recent withdrawals and changes in land use, Toms River, Metedeconk River, and Kettle Creek Basins, New Jersey

32. Map showing simulated water-level changes in model layer 2 from predevelopment conditions due to recent withdrawals and changes in land use in the Toms River, Metedeconk River, and Kettle Creek Basins, New Jersey

33. Map showing vertical flow directions across bottom of model layer 2 under recent (1989-92) conditions, Toms River, Metedeconk River, and Kettle Creek Basins, New Jersey

34. Graph showing predevelopment and recent (1989-92) ground-water budgets for Toms River, Metedeconk River, and Kettle Creek Basins, New Jersey .

35. Map showing areas in which location of ground-water divide has changed from predevelopment conditions, Toms River, Metedeconk River, and Kettle Creek Basins, New Jersey.

36. Graph showing recent (1989-92) and projected monthly ground-water withdrawals, Toms River, Metedeconk River, and Kettle Creek Basins, New Jersey.

37. Graph showing simulated water levels at model cell (layer, row, column) $=$ $(1,38,51)$ near Toms River Water Company, N.J., pumping center under predevelopment and recent (1989-92) conditions.

38. Graphs showing simulated typical monthly base flow under predevelopment and recent conditions of the (a) Toms River and (b) Metedeconk River, and monthly base-flow reduction for the (c) Toms River and (d) Metedeconk River, N.J

39. (a) Map showing locations of 10 hypothetical pumped wells; and graphs showing (b) average monthly recharge and base flow; and (c) average monthly reduction in base flow of the Toms River near Toms River, N.J. (01408500), in response to the constant withdrawal of 1 cubic foot per second from each of the wells........78 


\section{ILLUSTRATIONS--continued}

Page

Figure 40. Graphs showing sensitivity of zone of influence of Toms River Water Company, N.J., pumping center to changes in (a) hydraulic conductivity and recharge and (b) streambed conductance; and sensitivity of simulated base-flow reduction in the Toms River and Metedeconk River, N.J., to changes in (c) hydraulic conductivity and recharge and (d) layer 1 leakance.

41. Graphs showing sensitivity of predicted monthly base-flow reduction to changes in specific yield at five streamflow-gaging stations: (a) Toms River near Toms River, N.J.; (b) Toms River, (c) North Branch Metedeconk River near Lakewood, N.J.; (d) South Branch Metedeconk River at Lakewood, N.J.; and (e) Metedeconk River.

42. Map showing projected increases in pumpage from the Kirkwood-Cohansey aquifer system at full allocation, Toms River, Metedeconk River, and Kettle Creek Basins, New Jersey

43. Map showing average water-level declines and base-flow reduction due to projected 2010 withdrawals, Toms River, Metedeconk River, and Kettle Creek Basins, New Jersey

44. Map showing average water-level declines and base-flow reduction due to full-allocation withdrawals, Toms River, Metedeconk River, and Kettle Creek Basins, New Jersey.

45. Graph showing ground-water budgets for the Toms River, Metedeconk River, and Kettle Creek Basins, New Jersey, under recent conditions, for the projected 2010 alternative and for the full-allocation alternative.

46. Graphs showing simulated mean monthly base flow for the projected 2010 and full-allocation alternatives for (a) the Toms River, (b) the Metedeconk River, and (c) Kettle Creek, and mean monthly base-flow reduction during 1989-92 for (d) the Toms River, (e) the Metedeconk River, and (f) Kettle Creek, New Jersey

\section{TABLES}

Table 1. Stratigraphy and hydrologic characteristics of late Paleocene to Holocene units in the New Jersey Coastal Plain

2. Estimates of aquifer diffusivity and hydraulic conductivity from natural water-level fluctuations in four observation wells, Kirkwood-Cohansey aquifer system, New Jersey

3. Summary of model parameters, Kirkwood-Cohansey aquifer system, New Jersey....22

4. Simulated and observed water levels in wells in the Toms River, Metedeconk River, and Kettle Creek Basins, New Jersey

5. Statistics for water-level residuals, model layers 1 and 2, Toms River, Metedeconk

River, and Kettle Creek Basins, New Jersey 


\section{TABLES--Continued}

Page

Table 6. Correlation equations used to estimate average $1980-89$ base flow at 8 low-flow partial-record stations; estimated and simulated base flows at 10 streamflowgaging stations; and differences between estimated and simulated base flows, Toms River, Metedeconk River, and Kettle Creek Basins, New Jersey

7. Results of base-flow-sensitivity analyses in the Toms River, Metedeconk River, and Kettle Creek Basins, New Jersey

8. Simulated and observed water-level fluctuations in four observation wells, Toms River, Metedeconk River, and Kettle Creek Basins, New Jersey

9. Simulated base flows and base flows determined by hydrograph separation, June 1992-May 1993, Toms River, Metedeconk River, and Kettle Creek Basins, New Jersey

10. Simulated recent base flow and base-flow reduction, Toms River, Metedeconk River, and Kettle Creek Basins, New Jersey

11. Projected increases in ground-water withdrawals for 2010 and full-allocation alternatives, Toms River, Metedeconk River, and Kettle Creek Basins, New Jersey.

12. Predicted base-fiow reduction under 2010 and full-allocation alternatives, Toms River, Metedeconk River, and Kettle Creek Basins, New Jersey 


\section{CONVERSION FACTORS AND VERTICAL DATUM}

Multiply

inch (in.)

foot (ft)

mile (mi)

square mile $\left(\mathrm{mi}^{2}\right)$

foot per day $(\mathrm{ft} / \mathrm{d})$

cubic foot per second $\left(\mathrm{ft}^{3} / \mathrm{s}\right)$

cubic foot per second per square mile

$$
\left[\left(\mathrm{ft}^{3} / \mathrm{s}\right) / \mathrm{mi}^{2}\right]
$$

million gallons per day (Mgal/d)

gallon per minute per foot $[(\mathrm{gal} / \mathrm{min}) / \mathrm{ft}]$

Hydraulic conductivity

foot per day (ft/d)

0.3048

Transmissivity

square foot per day $\left(\mathrm{ft}^{2} / \mathrm{d}\right)^{1}$

Length

25.4

0.3048

1.609

Area

2.590

Flow

0.3048

0.02832

0.01093

0.04381

Specific capacity

0.2070

To obtain

square kilometer

liter per second per meter

meter per day

cubic meter per second

cubic meter per second per square kilometer

cubic meter per second

millimeter

meter

kilometer

Sea level: In this report "sea level" refers to the National Geodetic Vertical Datum of 1929-- a geodetic datum derived from a general adjustment of the first-order level nets of the United States and Canada, formerly called Sea Level Datum of 1929.

1 This unit is used to express transmissivity, the capacity of an aquifer to transmit water. Conceptually, transmissivity is cubic feet (of water) per day per square foot ( of aquifer area) times feet (of aquifer thickness), or $\left(\mathrm{ft}^{3} / \mathrm{d}\right) / \mathrm{ft}^{2} \mathrm{x} \mathrm{ft}$. In this report, this expression is reduced to its simplest form, $\mathrm{ft}^{2} / \mathrm{d}$. 


\title{
SIMULATION OF GROUND-WATER FLOW IN THE UNCONFINED AQUIFER SYSTEM OF THE TOMS RIVER, METEDECONK RIVER, AND KETTLE CREEK BASINS, NEW JERSEY
}

\author{
By Robert S. Nicholson and Martha K. Watt
}

\begin{abstract}
The unconfined Kirkwood-Cohansey aquifer system is a major source of water for coastal communities in Ocean and Monmouth Counties, New Jersey. Recent (1989-92) ground-water withdrawals from the Kirkwood-Cohansey aquifer system in the study area average about 15.5 million gallons per day. If present allocations were fully utilized, average withdrawals could increase to 25.6 million gallons per day, which could lower ground-water levels and reduce streamflows. In order to address concern about these effects, the U.S. Geological Survey, in cooperation with the New Jersey Department of Environmental Protection, conducted a study to describe and characterize the aquifer system, its interaction with surface water, and its response to withdrawals. Steady-state and transient numerical modeling techniques were applied to compare predevelopment and recent ground-water-flow patterns and to cstimate average and seasonal hydrologic effects of projected increases in ground-water withdrawals.
\end{abstract}

Simulation results indicate that ground-water withdrawals during the 1980's reduced average base flow in some streams as much as 11 percent from predevelopment base flow. Projected withdrawals at full-allocation levels would further reduce the average base flow of the Toms River, Metedeconk River, and Kettle Creck by about 2, 8, and 15 percent, respectively. Seasonal variations in base-flow reduction are controlled by seasonal variations in withdrawal rates and aquifer-storage effects. Seasonal reduction of base flow in the Toms River, Metedeconk River, and Kettle Creek with withdrawals at full-allocation levels would reach about 3, 14, and 26 percent, respectively. Increases in withdrawals projected to the year 2010 would result in smaller reductions in base flow.

Ground-water withdrawals during the 1980's shifted flow patterns in the KirkwoodCohansey aquifer system, causing average water-level declines of up to about 20 feet near pumping centers. Projected increases in withdrawals under conditions of full utilization of present allocations would result in additional declines of up to about 20 feet. Increases in withdrawals projected to the year 2010 would result in smaller water-level declines.

\section{INTRODUCTION}

The unconfined Kirkwood-Cohansey aquifer system is a major source of water supply for coastal communities in Ocean and Monmouth Counties, New Jersey (fig. 1). Ground-water discharge from this aquifer system to the Toms River, the Metedeconk River, Kettle Creek, and other tributaries is the largest source of freshwater inflow to northern Barnegat Bay and associated estuaries (fig. 2). Rapid population growth in Ocean and Monmouth Counties, coupled with restrictions on withdrawals from underlying confined aquifers (New Jersey Department of Environmental Protection, 1986), have resulted in increased demand for water from the unconfined aquifer system. As a result of the increase in withdrawals from shallow wells, water levels in the surficial aquifer have declined, reducing the discharge of fresh ground water to streams, wet- 


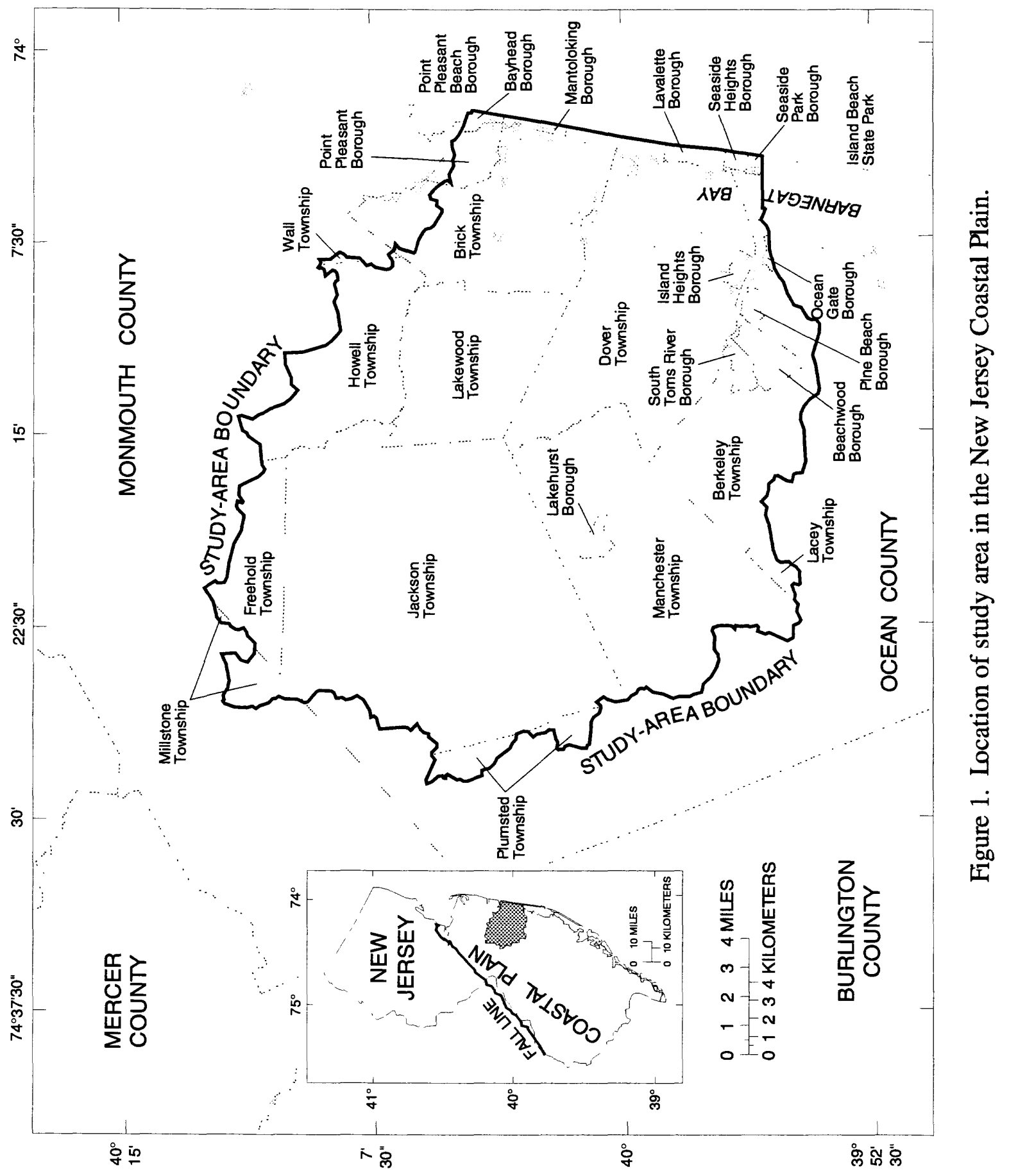




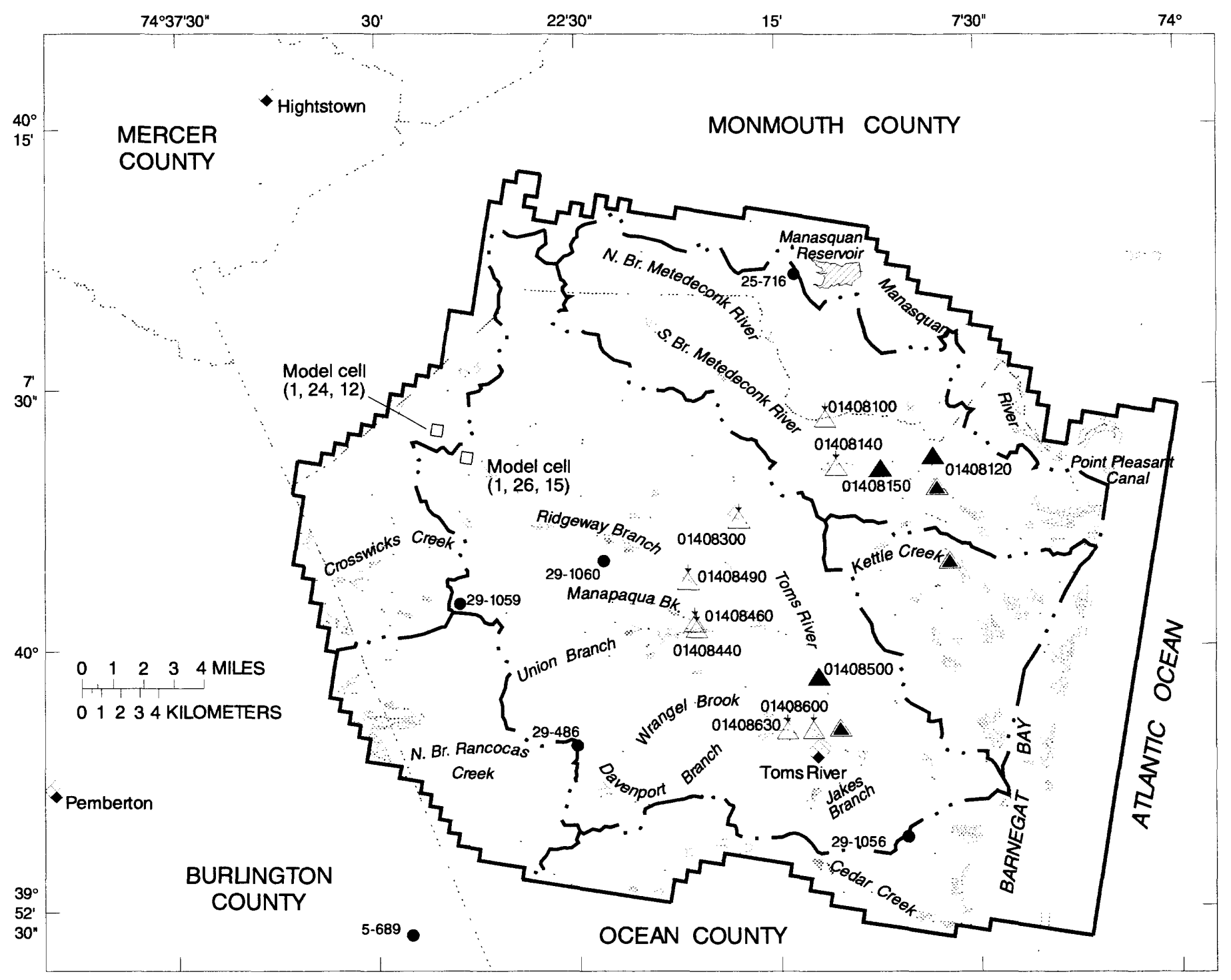

\section{EXPLANATION}

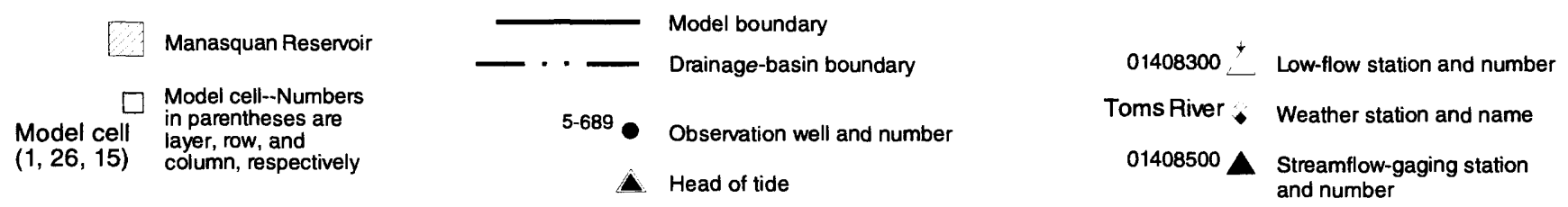

Figure 2. Location of model area, streamflow-gaging stations, low-flow stations, observation wells, and weather stations, Toms River, Metedeconk River, and Kettle Creek Basins, New Jersey. 
lands, Barnegat Bay, the associated estuaries, and the ocean. Changes in land use have contributed to declines in ground-water levels and reductions in the base-flow of streams by reducing the net rate of ground-water recharge in areas where land surfaces have been altered. The consequences of base-flow reduction can be most severe during periods of seasonally low flow. Water-level declines near the zone of saltwater in the aquifer system near the coast have resulted in the presence of elevated concentrations of chloride in some public-supply wells. Effective water-resource management aims to minimize these hydrologic effects of human activities and requires a detailed understanding of the ground-water-flow system under both average and seasonal conditions, its interactions with surface-water systems, and the changes that can result from additional withdrawals.

The U.S. Geological Survey (USGS), in cooperation with the New Jersey Department of Environmental Protection (NJDEP), compiled a summary of hydrologic information about the study area (Watt and others, 1994). This information provided the basis for the development of a three-dimensional numerical model of ground-water flow through the Kirkwood-Cohansey aquifer system. The model was used to refine the flow-system analysis presented in the previous report and to estimate the possible hydrologic effects of additional withdrawals. Simulated base flows can provide information useful for the study of surface-water flow and quality in the bay and estuaries.

\section{Purpose and Scope}

This report presents the results of three-dimensional numerical simulations of the unconfined ground-water-flow system in the Toms River, Metedeconk River, and Kettle Creek drainage basins. Results of numerical simulations are used to estimate aquifer-system properties, determine the hydrologic budget, determine ground-water-flow patterns, describe transient-flow characteristics, and estimate the hydrologic effects of recent and projected ground-water withdrawals. Estimates of changes in (1) the overall hydrologic budget, (2) average and seasonal base flow of streams, (3) average and seasonal ground-water levels, (4) the location of ground-water divides, and (5) leakage to underlying confined aquifers are included.

\section{Previous Investigations}

Watt and others (1994) provide information on the hydrogeologic framework, water levels, water use, geochemistry, and base flow in the study area and present a general hydrologic budget. Martin (in press) includes a conceptual model and analysis of ground-water flow in the New Jersey Coastal Plain that was used in the present investigation to determine the extent of the modeled area. An updated Coastal Plain model (D.A. Pope, U.S. Geological Survey, written commun., 1992) provides estimates of vertical leakances and lateral flows that were used in assigning boundary conditions.

\section{Well-Numbering System}

The well-numbering system used in this report is based on the system used by the USGS in New Jersey since 1978. It consists of a county code number followed by a sequence number of the well within the county. County codes used in this report are 25 for Monmouth County, 29 for Ocean County, and 5 for Burlington County. For example, well number 25-451 represents the 451 st well inventoried in Monmouth County. Construction details for wells with this type of identifier are stored in the USGS Ground-Water Site Inventory data base. 


\section{Acknowledgments}

Several officials at the NJDEP provided guidance for this project. Special thanks are extended to Scott Tyrrell and Jan Gheen of the NJDEP, Bureau of Water Allocation, for their help in planning the project, providing water-withdrawal data, and evaluating project results. The authors also express their gratitude to officials at Fort Dix, Naval Air Engineering Station at Lakehurst, Herbert Sand and Gravel Company, and Denzer and Schaefer, Inc., for providing access to wells for water-level measurements.

\section{GEOHYDROLOGIC SETTING}

The Kirkwood-Cohansey aquifer system in the study area consists of a southeastwarddipping wedge of unconsolidated sediments that include gravel, sand, silt, and clay. The geohydrologic units that comprise the aquifer system are the Kirkwood Formation, Cohansey Sand, and, depending on location, the Beacon Hill Gravel, Bridgeton Formation, and Cape May Formation (table 1). Underlying the Kirkwood-Cohansey aquifer system is the composite confining unit, a complex series of geologic units that, depending on location, can include as many as nine distinct units. The part of the composite confining unit of interest in this study ranges in age from Paleocene to early Miocene and is made up of the Vincentown Formation, Manasquan Formation, Shark River Formation, Piney Point Formation, and basal clay of the Kirkwood Formation. Two minor aquifers are present in this part of the composite confining unit. The Vincentown aquifer consists of the Vincentown Formation, which is composed of moderately permeable quartz sand. The Vincentown aquifer is used as a source of water only in and near the outcrop areas, in the northwestern part of the study area. The other minor aquifer, the Piney Point aquifer, is confined and is composed of fine- to coarse-grained glauconitic quartz sand and shell beds. The Kirkwood Formation is the youngest unit included in the composite confining unit. The basal part of the Kirkwood Formation, which makes up the upper part of the composite confining unit, contains regionally extensive clay layers. The upper part of the Kirkwood Formation, which is hydraulically connected to the overlying Cohansey Sand, is composed primarily of fine sand to fine gravel, and silty clay containing shell and organic matter. The Cohansey Sand is predominantly a very fine- to coarse-grained sand, with interbedded layers of clay and silty and clayey sand (Zapecza, 1989, p. B19). Near the coast, where the aquifer system is thickest, clay lenses up to many tens of feet thick are present, resulting in semiconfined conditions in the deep part of the aquifer system. The Beacon Hill Gravel is present in only a small part of the study area (Watt and others, 1994, fig. 1-4). It consists of sand and gravel, and is present below the water table only locally and near streams (Anderson and Appel, 1969, p. 54). The geology of the study area, including the stratigraphy and lithology of the sediments, is described in greater detail by Anderson and Appel (1969), Jablonski (1968), and Watt and others (1994).

The upper part of the Kirkwood Formation and the Cohansey Sand are hydraulically well connected and together function as an aquifer system. The aquifer system thins to the north and west and is underlain by a confining unit, the basal clay of the Kirkwood Formation, which separates it from underlying confined aquifers (fig. 3). The Vincentown aquifer and the KirkwoodCohansey aquifer system are well connected in areas where the intervening confining unit is thin or absent. The Kirkwood-Cohansey aquifer system is less well connected with the Piney Point aquifer. The Kirkwood-Cohansey aquifer system thins to a featheredge at its northwestern limit, where land-surface elevations exceed $200 \mathrm{ft}$ in some areas. The aquifer system thickens downdip to about $250 \mathrm{ft}$ at the southeastern limit of the study area in Seaside Park Borough on the barrier island, where land-surface elevations are at or near sea level. The shallow part of the flow system 
Table 1. Stratigraphy and hydrologic characteristics of late Paleocene to Holocene units in the New Jersey Coastal Plain

[Modified from Zapecza, 1989, table 2]

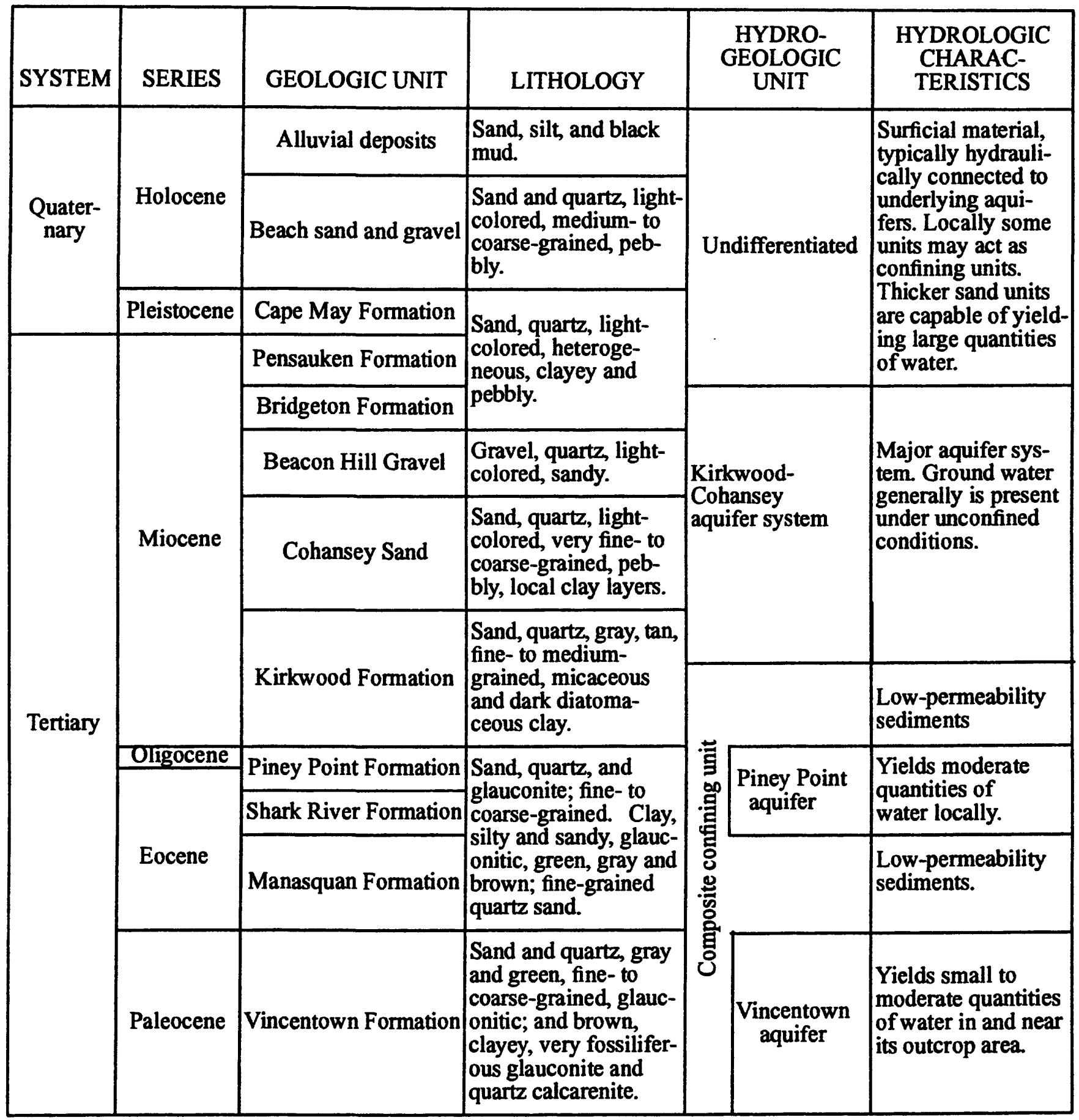




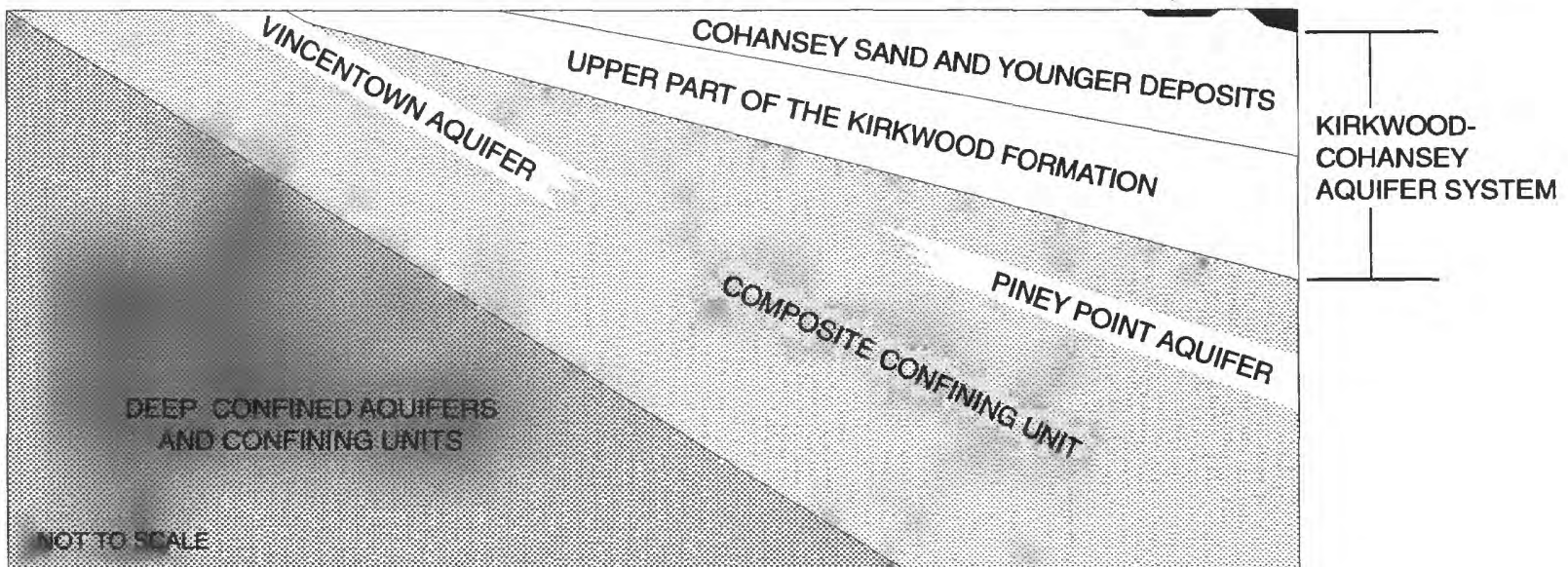

Figure 3. Generalized hydrogeologic section through the study area, Toms River, Metedeconk River, and Kettle Creek Basins, New Jersey. 
is presumed to be bounded by salty water beneath Barnegat Bay and the ocean as inferred from Anderson and Appel $(1969$, figs. 9, 19). The seaward extent of freshwater in the deep part of the flow system is unknown.

Average annual precipitation in the study area is about 47 inches. Average annual evapotranspiration (ET) is about one-half this amount ( 23 inches). The aquifer system receives recharge through infiltration of precipitation which is typically highest during winter months when ET is low and lowest during summer months when ET is high. In wetland areas, where the water table is near land surface, direct loss of ground water from the water table (ground-water ET) is high.

Ground water generally flows from northwest to southeast. Some ground water follows short flow paths and discharges locally to surface water bodies. Some ground water follows longer, deep flow paths and discharges to more distant streams or other surface-water features at lower elevations.

Streams and other surface-water features generally are in good bydraulic connection with the aquifer system. Streams generally gain flow throughout the year, although stream reaches may lose flow during floods and when pumping from nearby shallow supply wells induces surface water to flow into the aquifer. Annual ground-water discharge to streams (base flow) historically has been 80 to 89 percent of total annual streamflow of the Toms River near Toms River, N.J. (01408500), and 63 to 79 percent of total annual streamflow of the North Branch Metedeconk River near Lakewood, N.J. (01408120) (Watt and others, 1994). Base flow accounts for 100 percent of streamflow during periods of low precipitation.

Reported ground-water withdrawals from the aquifer system increased from $9.9 \mathrm{Mgal} / \mathrm{d}$ to $14.7 \mathrm{Mgal} / \mathrm{d}$ from 1975 through 1988 , an increase of 49 percent over 14 years (Watt and others, 1994, table 5-2). Average withdrawals from the Kirkwood-Cohansey aquifer system in the study area totaled about $15.5 \mathrm{Mgal} / \mathrm{d}$ during 1989-92 (U.S. Geological Survey Site-Specific Water-Use Data System, unpublished data on file at the U.S. Geological Survey office in West Trenton, N.J.), and most withdrawals were from wells located within about $12 \mathrm{mi}$ of the coast. Withdrawals from the Kirkwood-Cohansey aquifer system are expected to increase in the future as the population of coastal communities expands and as other sources of water supply within and near the study area become limited.

\section{SIMULATION OF GROUND-WATER FLOW}

The ground-water-flow model was designed to create an accurate mathematical representation of the flow system that would be capable of simulating flow and head distribution with sufficient accuracy and resolution to facilitate a detailed quantitative analysis of the regional flow system. The model also can be used to predict the probable hydrologic changes that would result from projected increases in withdrawals. The model design was guided by concepts of the flow system that have been developed through previous analysis of the study area by Watt and others (1994) and through other investigations of ground-water flow in the New Jersey Coastal Plain. The model code used was the USGS modular model (MODFLOW) by McDonald and Harbaugh (1988). Aquifer and confining-unit geometries were determined primarily from the regional description of the hydrogeologic framework of the New Jersey Coastal Plain by Zapecza (1989). Aquifer and confining-unit geometries in the northwestern part of the study area were refined on 
the basis of geologic and geophysical well logs. Model boundaries were selected to coincide with hydrologic boundaries wherever possible. The three-layer conceptual model and model boundaries are shown in figure 4.

Model recharge boundaries include those representing (1) areal recharge to the uppermost model layer, (2) flow from the Piney Point aquifer underlying the southeastern part of the study area, (3) flow from shallow sediments underlying the estuary and ocean containing salty ground water, (4) flow from offshore areas to the lower part of the aquifer system, and (5) flow from streams (stream leakage). Model discharge boundaries include those representing (1) flow to gaining streams, (2) discharge to withdrawal wells, (3) flow to the Piney Point aquifer, (4) flow to shallow sediments containing salty water, (5) flow from the lower part of the system to offshore areas, and (6) ET from the water table in wetland areas where the water table is near land surface.

Model hydraulic characteristics were initially estimated from results of aquifer tests, laboratory tests, and well-performance tests; sediment-texture data; and results of other modeling studies. Hydraulic characteristics were then refined by calibration. The following sections describe in greater detail the aquifer-system geometry and model-grid design, boundaries, and bydraulic characteristics.

\section{Aquifer-System Geometry and Model-Grid Design}

Aquifer and confining-unit geometries in the study area were determined primarily from the regional description of the hydrologic framework of the New Jersey Coastal Plain by Zapecza (1989). The regional framework was refined locally in the northwestern part of the study area where the scale of the available data was too coarse to meet the requirements for detailed modeling. The framework description was refined on the basis of examination of many geologic and geophysical well logs. The results of these refinements are reflected in the discretized geometries of aquifers and confining units.

For the purpose of model discretization, the regional framework description by Zapecza $(1989, \mathrm{pl} .23,24)$ adequately defines the altitude of the base of the Kirkwood-Cohansey aquifer system and its thickness over most of the study area. In the northwestern part of the study area, where aquifers are thinnest, additional data from geophysical well logs indicate that the base of the Kirkwood-Cohansey aquifer system reaches a maximum altitude of about $165 \mathrm{ft}$ (fig. 5). The thickness and altitude of the base of the Vincentown aquifer in the northwestern part of the study area were similarly refined.

The extent and thickness of the confining unit between the Kirkwood-Cohansey aquifer system and the Vincentown aquifer, which is the basal clay of the Kirkwood Formation, in the northwestern part of the study area also were refined. Many geologic and geophysical logs of wells penetrating the Kirkwood Formation in this area do not show evidence of this characteristic clay, suggesting that in some areas a good hydraulic connection is present between the overlying Kirkwood-Cohansey aquifer system and the underlying Vincentown aquifer. Where the Kirkwood Formation crops out in the study area, the basal Kirkwood clay unit has not been mapped and is considered unmappable (Peter Sugarman, N.J. Geological Survey, oral commun., 1992). At its updip limit, the basal Kirkwood clay may pinch out and be covered by coarser sediments (James Owens, U.S. Geological Survey, oral commun., 1993). The estimated updip limit of the basal Kirkwood clay is shown in figure 5 . 


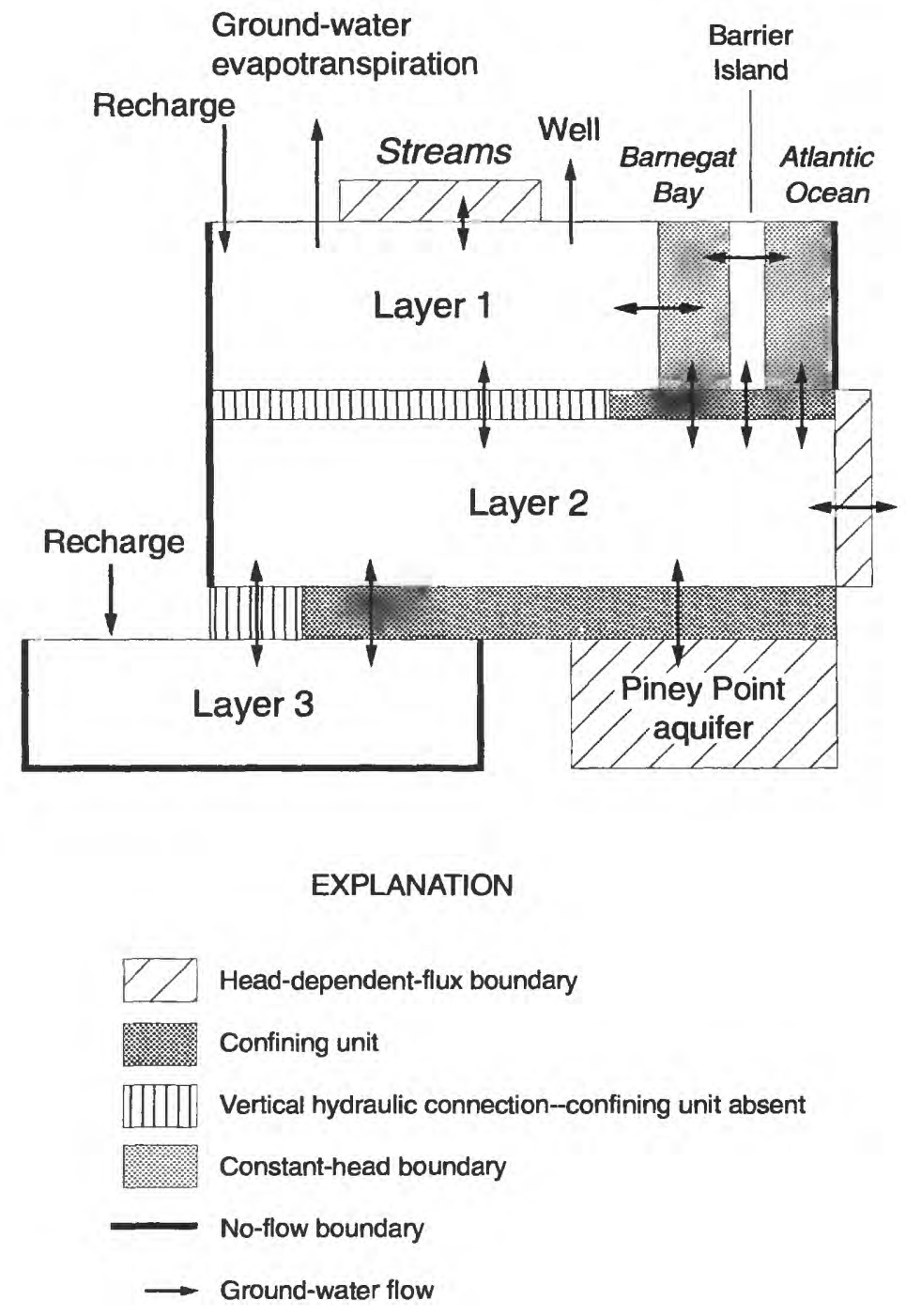

Figure 4. Schematic representation of the ground-water-flow system, Toms River, Metedeconk River, and Kettle Creek Basins, New Jersey. 


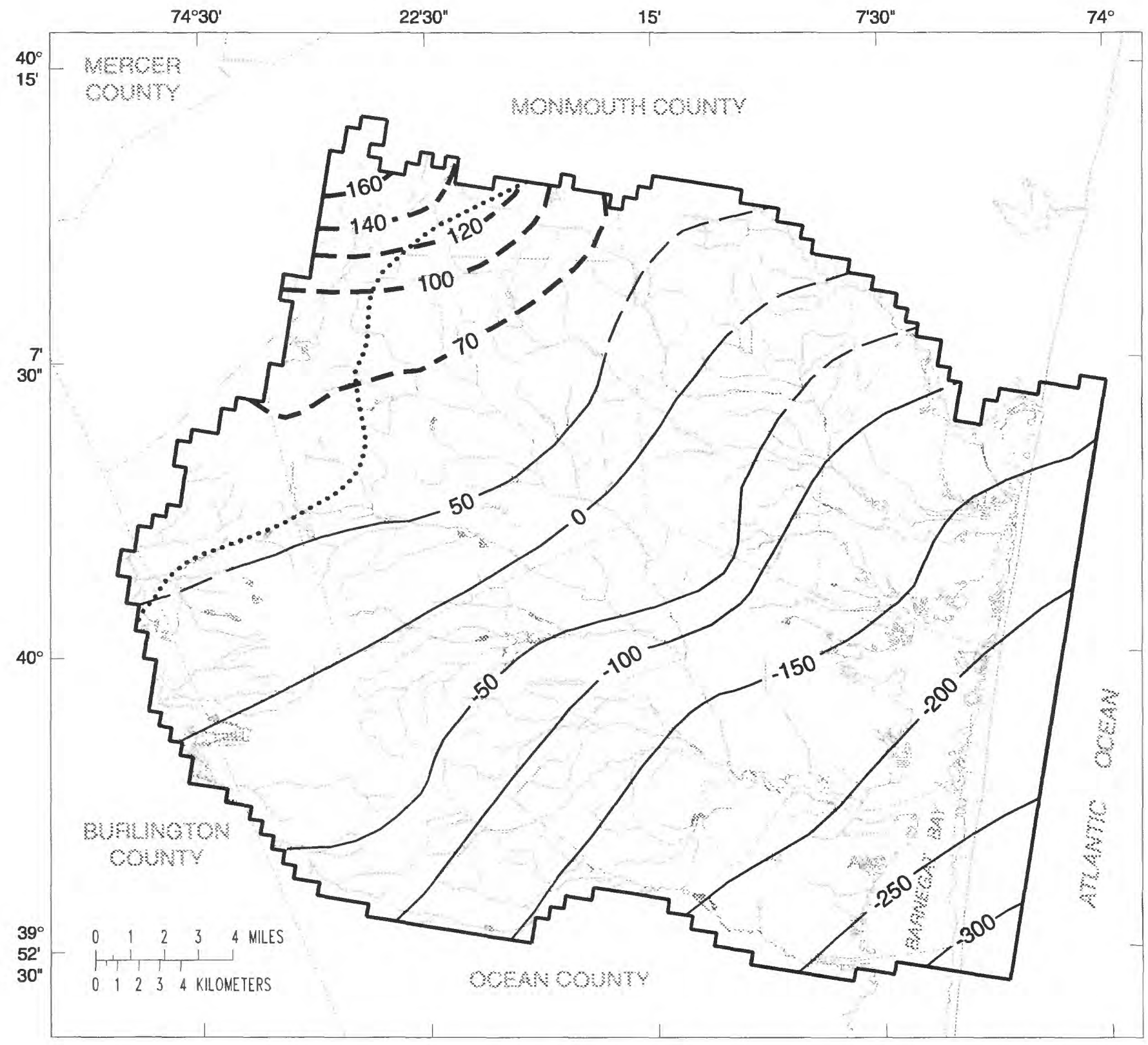

\section{EXPLANATION}

- 50 - STRUCTURE CONTOUR-Shows altitude of base of the Kirkwood-Cohansey aquifer system (Zapecza, 1989, pl. 23). Dashed where approximately located. Interval 50 feet.

Datum is sea level

- -70 - - STRUCTURE CONTOUR-Shows altitude of base of the Kirkwood-Cohansey aquifer system. Interval 20 and 30 feet. Datum is sea level

............... Updip limit of the basal clay of the Kirkwood Formation

Model boundary, layers 1 and 2

Figure 5. Structure contours of the base of the Kirkwood-Cohansey aquifer system, Toms River, Metedeconk River, and Kettle Creek Basins, New Jersey. 
The aquifer system was discretized vertically on the basis of regional flow concepts. Shallow and deep flow regimes are present in the aquifer system, as described by Rhodehamel (1970). In order to simulate both flow regimes and accurately represent the physical factors that control them, two model layers were necessary to represent the Kirkwood-Cohansey aquifer system (fig. 6). Model layer 1 represents the upper part of the aquifer system, which consists of the Cohansey Sand and younger deposits, and model layer 2 represents the lower part, which consists of the upper part of the Kirkwood Formation. In areas where the upper part of the aquifer system includes both Kirkwood Formation and Cohansey Sand sediments, model layer 1 represents a composite of both units. In areas where the Kirkwood Formation crops out, layers 1 and 2 both represent permeable Kirkwood Formation sediments. Layer 1 and 2 each have a mean thickness of $61 \mathrm{ft}$.

A third model layer represents the Vincentown aquifer where it is present in the study area. Flow in the Vincentown aquifer is simulated explicitly because the Vincentown aquifer is in good hydraulic connection with the Kirkwood-Cohansey aquifer system in the northwestern part of the study area, where the intervening basal Kirkwood confining unit is thin or absent, and the rate of flow between the aquifers is considerable. The Vincentown aquifer crops out in some northern and western parts of the study area (fig. 7). The average thickness of layer 3 is $41 \mathrm{ft}$.

The model area was discretized horizontally into a grid consisting of 61 rows and 75 columns, defining grid cells with a uniform horizontal nodal spacing of $2,000 \mathrm{ft}$ (fig. 7). This nodal spacing provides model resolution adequate for defining increasing gradients toward surface-water boundaries on a regional scale and for representing nearly all first-order-stream reaches discretely. The total number of active cells is 8,187 .

\section{Boundary Conditions}

The extent of the model area, horizontal discretization, boundary conditions, and internal boundaries representing surface-water features are illustrated in figure 7. Model boundaries were selected to coincide with natural hydrologic boundaries wherever practical. The lateral extent of the model was expanded beyond the drainage areas of the Toms and Metedeconk Rivers to coincide with adjacent major streams to the north, south, and southwest, and to coincide with the updip limit of the Vincentown aquifer to the northwest. This boundary placement facilitates the simulation of shifts in the location of the ground-water divide in response to pumping. To the east, the flow system is bounded by a saltwater/freshwater interface. The presence of salty water is the probable result of the hydraulic connection among the shallow aquifer, the ocean, and the estuary and of the mixing of fresh and salty water by tidal fluctuations. The head in this shallow zone is expected to remain within the narrow range of tidal fluctuations of bay and ocean levels. For this reason, the shallow subsurface sediments beneath the bay and ocean were represented by constant-head boundaries in model layer 1 .

The model was extended offshore to a plausible location of the saltwater/freshwater interface in the deep part of the Kirkwood-Cohansey aquifer system. Recent increases in chloride concentrations in withdrawal wells at Seaside Heights Borough indicate that the interface probably is moving landward locally in response to ground-water withdrawals from the deep part of the aquifer system. The potential for flow into the model area from beyond the model boundary is represented by assigning a general-head boundary condition to the offshore model limit in layer 2 (fig. 7). 


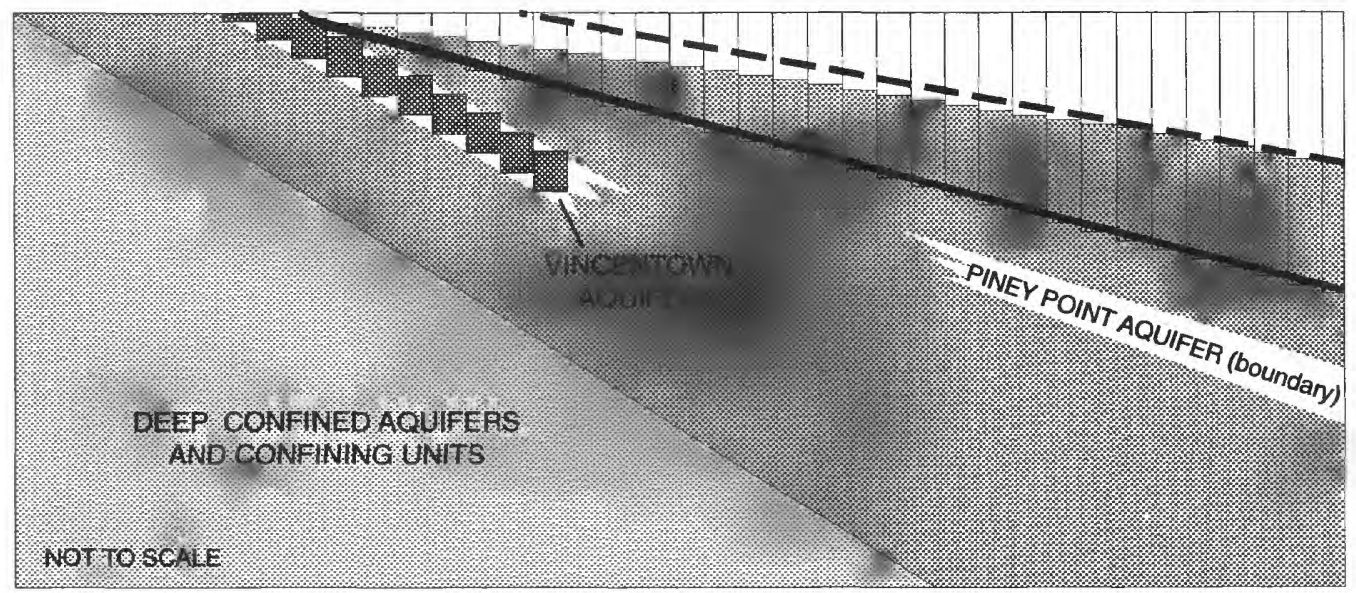

\section{EXPLANATION}

Model cell in layer 1 (Cohansey Sand or upper part of Kirkwood Formation or both)

Model cell in layer 2 (upper part of Kirkwood Formation)

Model cell in layer 3 (Vincentown aquifer)

Base of the Kirkwood-Cohansey aquifer system

Contact between Cohansey Sand and Kirkwood Formation

Figure 6. Diagrammatic section showing relation between aquifer units and model layers in the ground-water-flow model, Toms River, Metedeconk River, and Kettle Creek Basins, New Jersey. 


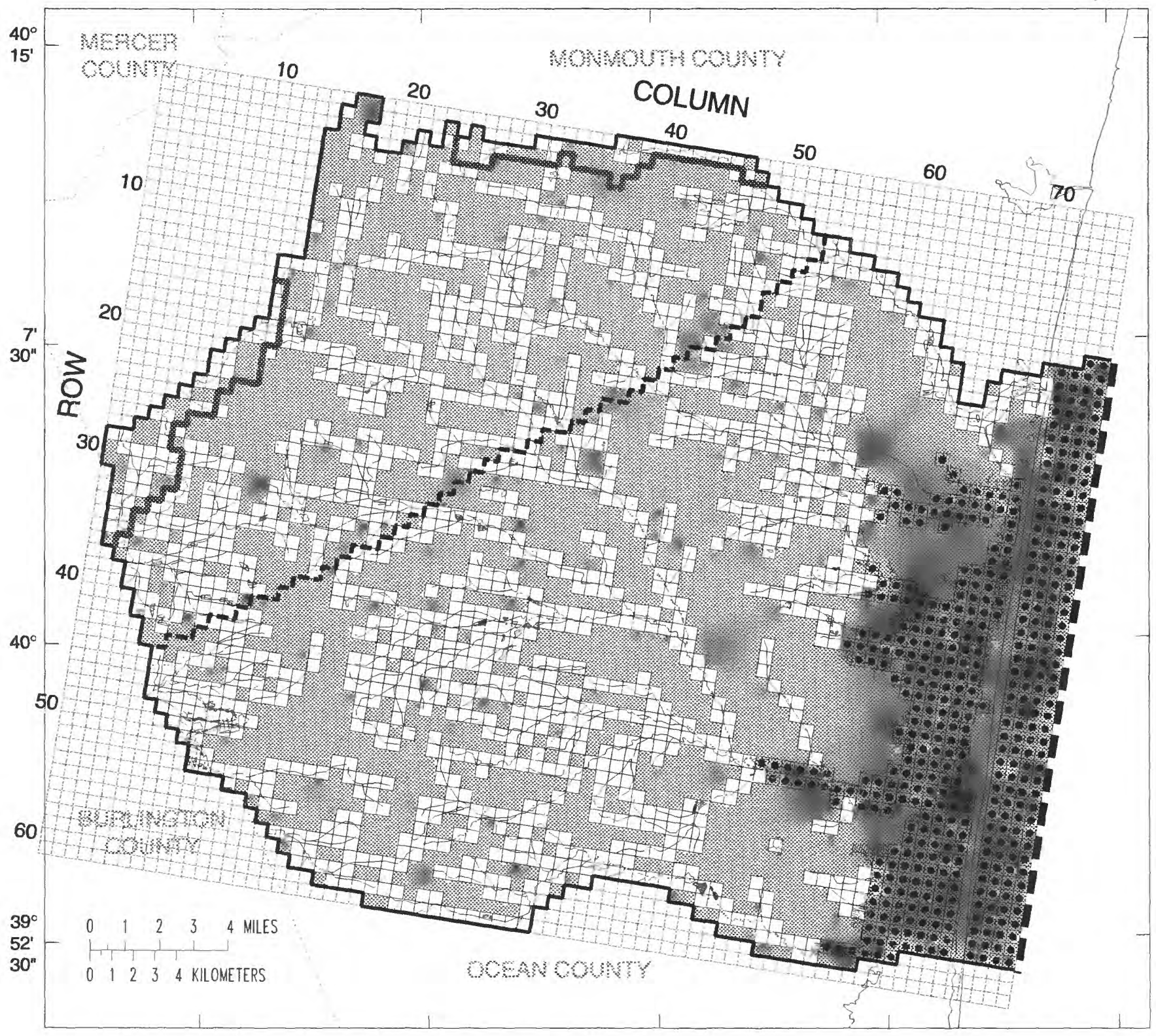

\section{EXPLANATION}

$\square$ Head-dependent-flux boundary (stream reach)

Constant-head boundary (embayment or ocean)

No-flow boundary

- No-flow boundary in model layer 1;

head-dependent-flux boundary in model layer 2

Limit of area where model layer 3 is unconfined; no-flow boundary in layers 1 and 2

Downdip limit of layer 3

Figure 7. Model grid, lateral boundaries, and internal boundaries representing surface-water features, Toms River, Metedeconk River, and Kettle Creek Basins, New Jersey. (Model-cell size is 2,000 feet by 2,000 feet) 
The Vincentown aquifer underlies part of the Kirkwood-Cohansey aquifer system and extends beyond the model area to the northeast and southwest. Simulations of regional groundwater flow in the New Jersey Coastal Plain indicate that flow across the model boundary in the Vincentown aquifer is negligible (D.A. Pope, U.S. Geological Survey, written commun., 1992). A no-flow condition is specified along this boundary in model layer 3 .

The aquifer system is also hydraulically connected with the underlying Piney Point aquifer in the southeastern part of the study area. The Piney Point aquifer is confined by a silty clay in the basal part of the Kirkwood Formation (Zapecza, 1989), and leakage to this aquifer is slight (Watt and others, 1994, sheet 5). Locally, however, in areas where the confining unit is more permeable, leakage may be substantial (Modica, 1996, p. 34-35). Vertical flow to and from the Piney Point aquifer is represented by a head-dependent-flow boundary; thus, the model estimates changes in leakage rates to the Piney Point aquifer that result from additional withdrawals from the Kirkwood-Cohansey aquifer system. Boundary heads in the Piney Point aquifer were determined from potentiometric-surface maps developed from synoptic water-level surveys and historical water levels. Leakances representing flow through the composite confining unit between the Kirkwood-Cohansey aquifer system and the Piney Point aquifer were interpolated from leakances used in regional simulations of the New Jersey Coastal Plain (D. A. Pope, written commun., 1992). Heads in the Piney Point aquifer are affected by withdrawals from wells located far to the south of the study area; therefore, simulation of flow in the Piney Point aquifer was impractical.

\section{Recharge}

From water-budget analyses, Watt and others (1994) estimated annual recharge for the Toms and Metedeconk River Basins to be 19.4 and 15.0 inches, respectively. The difference in recharge rates was attributed primarily to a higher percentage of urban land in the Metedeconk River Basin. Paved surfaces prevent infiltration of precipitation, increasing direct runoff and decreasing recharge. Model cells in which urban areas occupy more than 50 percent of the cell area were identified by using geographic information system (GIS) coverages and are shown in figure 8 . Recharge was assumed to be reduced 20 percent in these intensely urbanized areas. The primary basis for this assumption is the results of model calibration; lower recharge rates in these areas were required in order to reproduce urban-area base flows determined from streamflow data. The resulting recharge rate is the net recharge rate assumed to occur over urban areas, after all effects of urbanization are taken into account; in addition to reduced infiltration over paved surfaces, exfiltration from sewer lines and dewatering activities can reduce recharge (Reilly and Buxton, 1985, p. 18), whereas other processes in urban areas, such as infiltration of stormflow through retention/detention basins ( $\mathrm{Ku}$ and others, 1992) and leaking water-supply lines (Reilly and Buxton, 1985, p. 18), can increase recharge.

An analysis of base flow in several streams in the study area and results of preliminary simulations indicate possible geologic control on recharge. Base flow per unit area of streams draining areas underlain primarily by the Kirkwood Formation is less than that of streams draining areas underlain by the Cohansey Sand. Preliminary simulations in which previously determined rates of recharge over the Toms and Metedeconk River Basins were used resulted in overestimation of base flow in streams draining non-urban areas underlain by the Kirkwood Formation. This discrepancy may result from the difference in hydraulic conductivity between the sediments of the Kirkwood Formation and those of the Cohansey Sand. The hydraulic conduc- 


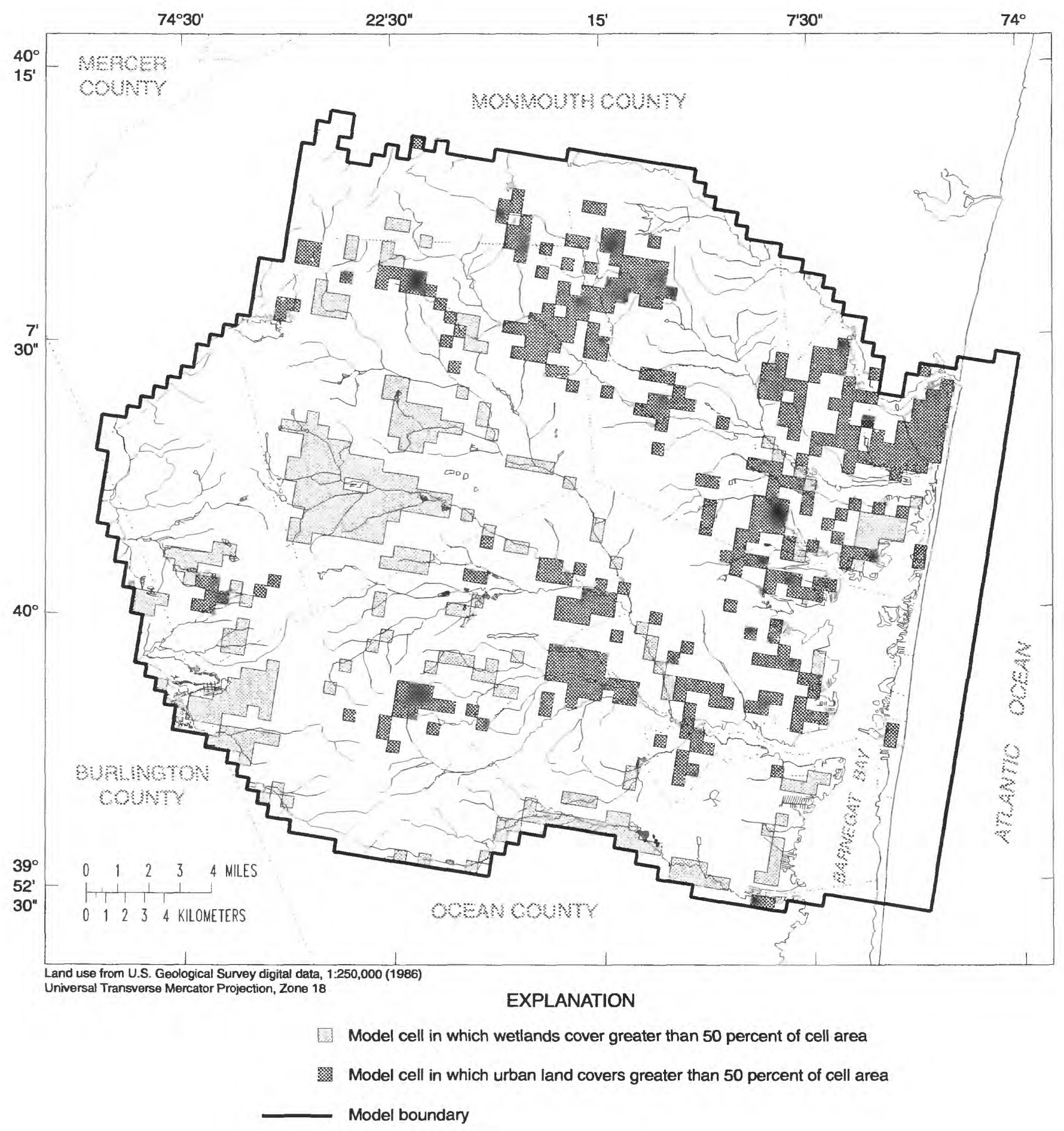

Figure 8. Wetland and urban areas in the Toms River, Metedeconk River, and Kettle Creek Basins, New Jersey. 
tivity of the Kirkwood Formation is generally considered to be lower than that of the Cohansey Sand (Anderson and Appel, 1969, p. 15-16; Rhodehamel, 1973, p. 24; Harbaugh and Tilley, 1984, p. 7) as a result of the contrast in texture between these two units in the study area. This textural contrast is described by Sugarman and others (1991). It is reasonable to expect that the Kirkwood Formation generally receives less recharge where it crops out than does the Cohansey Sand as a result of lower rates of infiltration. Modica (1996, p. 17) reached a similar conclusion through an analysis of ground-water flow in the Rancocas River Basin in the New Jersey Coastal Plain. In the model developed for this study, an annual recharge of 16.8 inches was used over the non-urban areas where the Kirkwood and Vincentown Formations crop out, whereas an annual rate of 21.6 inches was used in non-urban areas downdip from the outcrop of the Kirkwood Formation. Cells in urban areas where the Kirkwood and Vincentown Formations crop out received the lowest annual recharge of 13.4 inches. Cells in urban areas downdip from the Kirkwood Formation outcrop received annual recharge of 17.3 inches. The average annual rate of recharge was 20.2 inches for cells in the Toms River Basin and 16.7 inches for cells in the Metedeconk River Basin. These average values are slightly higher than those estimated for the respective basins by Watt and others (1994). In simulations, however, ET from the water table was treated separately as a specifiedflux boundary and, if the estimated rate of ground-water ET is subtracted from these average recharge rates, the "net" recharge rates are nearly identical to those estimated by Watt and others (1994).

\section{Ground-Water Evapotranspiration}

The water table in the study area is near land surface over broad areas of low relief. The potential exists for substantial rates of ET directly from the water table to occur in these areas. The Ridgeway Branch drainage basin above the streamflow-measurement station Ridgeway Branch near Lakehurst, N.J. (01408490, fig. 2), is approximately 42 percent wetlands, and the estimated unit base flow at that site $\left(1.23\left(\mathrm{ft}^{3} / \mathrm{s}\right) / \mathrm{mi}^{2}\right)$ is lower than that of most other Toms River tributaries. These characteristics indicate that ground-water ET most likely is an important process in the shallow-ground-water budget of this subbasin and locally in other wetland areas. If ground-water ET were a regionally dominant process, then streamflow recession curves would exhibit a characteristic downward-curving slope, or "signature," during summer recessions, as described by Daniel (1976). Streamflow data from historical periods of low flow were scanned for the ground-water ET signature but no consistent pattern was evident in the record of either the Toms River or the North Branch Metedeconk River. Ground-water ET may be important locally, however, in subbasins with a high percentage of wetlands where ground water is readily available for ET.

Ground-water ET was incorporated into simulations by identifying model cells where land cover is predominantly wetlands, and then imposing a specified-flux boundary on those cells by using the Evapotranspiration Package of MODFLOW (McDonald and Harbaugh, 1988). The locations of ground-water ET boundary cells are shown in figure 8. Wetland cells were identified by using GIS coverages of the model grid and land use/land cover (U.S. Geological Survey, 1986). The boundary flux was not permitted to vary with depth to water because, at the regional scale of the simulations, such variation would be highly sensitive to both model error and the limited accuracy of available land-surface-elevation data. Instead, a predetermined average rate of flux was specified at wetland cells. The effect of ground-water ET could have been simulated equivalently by specifying correspondingly lower recharge rates. Ground-water ET was treated separately, however, in order to allow recharge and ground-water ET rates to be adjusted independently during calibration and to allow for simpler construction of detailed simulated ground-water budgets. After repeated model runs in which different ground-water ET rates for wetlands were used, an estimated annual ground-water ET rate of 10.2 inches was selected. 


\section{Surface-Water Boundaries}

Model boundaries representing surface-water bodies are shown in figure 7. Gaining streams were represented by head-dependent-flow boundaries, implemented with the MODFLOW Drain Package (McDonald and Harbaugh, 1988). Discharge to drain boundaries is determined as proportional to the difference between simulated head in the aquifer and a boundary elevation representing stream stage. The constant of proportionality is the streambed conductance, which was determined as the product of streambed hydraulic conductivity, stream length, and stream width divided by streambed thickness. Stream width was estimated on the basis of stream order, so that streambed conductance is generally lower for headwater streams than for main-stem reaches. When simulated head in the aquifer is lower than the drain elevation, as can occur in headwater areas, flow to the drain ceases. This approach allows the location of start of flow to change seasonally.

Potential losing streams were identified and were represented by head-dependent-flow boundaries, implemented with the MODFLOW River Package (McDonald and Harbaugh, 1988). Streambed conductance and stage were determined for losing streams in a manner similar to that used to define gaining-stream boundaries. Riverbed-bottom elevations were set to $3.0 \mathrm{ft}$ below river stage. When simulated head in the aquifer is lower than the river-boundary elevation, water flows from the river into the aquifer. If the simulated head falls below the bottom of the riverbed, induced infiltration is limited to that occurring under a unit gradient.

\section{Hydraulic Properties of Aquifers and Confining Units}

Data on aquifer transmissivity, hydraulic conductivity, storage coefficient, and vertical hydraulic conductivity of confining units were compiled from the literature; these data include results of aquifer tests, laboratory analyses, well-performance tests, and other modeling studies. Because values were determined through different approaches, they are not entirely comparable; however, the examination of results of different types of analyses provides a general framework for evaluating the hydraulic properties of the units of interest. For the purpose of simulating ground-water flow, properties of aquifers and confining units were initially estimated on the basis of the information from previous tests and investigations. Values of hydraulic properties were subsequently adjusted during calibration of the model (described in a later section). Final calibrated values of properties used in simulations of the flow system are presented in this section.

\section{Kirkwood-Cohansey Aquifer System}

Watt and others (1994, sheet 2) discuss hydraulic properties of the Kirkwood-Cohansey aquifer system determined from four aquifer tests conducted in and near the study area and note the limitations of the analyses used to interpret the tests. The range of values of horizontal hydraulic conductivity reported for these tests is 9 to $140 \mathrm{ft} / \mathrm{d}$. A single value of specific yield of 0.024 was reported, which is considered low for an unconfined aquifer. An additional aquifer test relevant to this study was conducted in the Mullica River Basin (Atlantic and Burlington Counties) $20 \mathrm{mi}$ southwest of the study area, and is described by Lang and Rhodehamel (1963) and Rhodehamel (1979). The test resulted in a specific-yield estimate of 0.16 for the KirkwoodCohansey aquifer system (Rhodehamel, 1973, p. 31), which is more representative of the aquifer within the study area. Another test, reported by Anderson and Appel (1969, p. 48), indicates a confined storage coefficient of $6 \times 10^{-4}$ for the lower part of the Kirkwood-Cohansey aquifer system. 
Though the sediments of the Cohansey Sand and the Kirkwood Formation are considered part of a single aquifer system, the hydraulic properties of the two units differ, and these differences have a substantial effect on the flow system. In addition to previous studies cited in the Recharge section of this report, results of slug tests and well-performance tests at the Ciba-Geigy industrial site in Toms River, N.J., indicate that hydraulic conductivity decreased with depth in the Kirkwood-Cohansey aquifer system (NUS Corporation, 1988, p. 4-39; Camp Dresser and Mckee, Inc., 1988, table E-2).

Because the natural fluctuation of ground-water levels is related to the hydraulic characteristics of the aquifer system, comparison of water-level fluctuations in observation wells screened in different units provides alternate means for determining contrasts in bydraulic characteristics between the units. Aquifer diffusivity [defined as transmissivity $(\mathrm{T})$ divided by storage coefficient (S)] was determined from the slope of natural water-level recessions in four observation wells by using a method developed by Rorabaugh (1960). The method relates aquifer diffusivity to the slope of the recession curve, the distance between the nearest ground-water divide and the nearest stream, and the stream stage. The equation ${ }^{1}$ used is

$$
T / S=\frac{0.933}{\left(t_{2}-t_{1}\right)} a^{2} \log \left(h_{1} / h_{2}\right),
$$

where $\mathrm{T} / \mathrm{S}$ is diffusivity, in $\mathrm{ft}^{2} / \mathrm{d}$;

a is distance from stream to ground-water divide, in $\mathrm{ft}$;

$\mathrm{h}_{1}$ is starting water level, in $\mathrm{ft}$;

$\mathrm{h}_{2}$ is ending water level, in $\mathrm{ft}$;

$t_{1}$ is an arbitrary point on the log-linear part of the recession curve that corresponds to $\mathrm{h}_{1}$, in days; and

$t_{2}$ is an arbitrary point on the log-linear part of the recession curve that corresponds to $\mathrm{h}_{2}$, in days.

The locations of the four observation wells used in this analysis are shown in figure 2: Lakehurst observation well (29-1060), Ft. Dix observation well (29-1059), Crammer observation well (29-486), and Herbert Sand observation well (25-716). The Herbert Sand observation well (25-716) is open to the Kirkwood Formation and the other three are open to the Cohansey Sand. (Additional well-construction information can be found in the appendix.) One additional well, the D and S observation well (29-1056), was monitored but was not used in this analysis. No stream reaches were located near the well and ground-water withdrawals affected water levels. The four estimates of diffusivity, along with independent estimates of specific yield and aquifer thickness, were used to calculate values of aquifer transmissivity and horizontal hydraulic conductivity. Results of the analysis are listed in table 2 .

1 This analysis is valid only when the recession curve is a straight line when plotted on semilog paper. Water levels fall exponentially with time and the profile shape stabilizes only after sufficient time has elapsed. After that critical time, aquifer diffusivity can be computed from the slope of the recession at any well (Rorabaugh, 1960, p. 314). 
Table 2. Estimates of aquifer diffusivity and hydraulic conductivity from natural water-level fluctuations in four observation wells, Kirkwood-Cohansey aquifer system, New Jersey

[ $\mathrm{ft}^{2} / \mathrm{d}$, feet squared per day; $\mathrm{f} / \mathrm{d}$, feet per day; C, Cohansey Sand; K, Kirkwood Formation]

\begin{tabular}{|c|c|c|c|c|c|c|c|c|c|c|c|c|}
\hline $\begin{array}{l}\text { U.S. } \\
\text { Geological } \\
\text { Survey } \\
\text { well } \\
\text { number }\end{array}$ & $\begin{array}{l}\text { Period } \\
\text { of } \\
\text { recession }\end{array}$ & $\begin{array}{l}\text { End of } \\
\text { estimate } \\
\text { range }\end{array}$ & $\begin{array}{c}\text { Stream } \\
\text { eleva- } \\
\text { tion } \\
\text { (feet } \\
\text { above } \\
\text { sea } \\
\text { level) }\end{array}$ & $\begin{array}{l}\text { Starting } \\
\text { water } \\
\text { level, } \\
\left(\mathrm{h}_{1}\right)^{1} \\
\text { (feet } \\
\text { above } \\
\text { stream } \\
\text { stage) }\end{array}$ & $\begin{array}{l}\text { Ending } \\
\text { water } \\
\text { level, } \\
\text { (h/ }) \\
\text { (feet } \\
\text { above } \\
\text { stream } \\
\text { stage) }\end{array}$ & $\begin{array}{l}\text { Distance } \\
\text { between } \\
\text { ground- } \\
\text { water } \\
\text { divide } \\
\text { and } \\
\text { stream } \\
\text { (a) } \\
\text { (feet) }\end{array}$ & $\begin{array}{l}\text { Diffus- } \\
\text { iviy } \\
\left(\mathrm{ft}^{2} / \mathrm{d}\right)\end{array}$ & $\begin{array}{l}\text { Assumed } \\
\text { specific } \\
\text { yield (s) } \\
\text { (dimen- } \\
\text { sion- } \\
\text { less) }\end{array}$ & $\begin{array}{l}\text { Trans- } \\
\text { miss- } \\
\text { ivity } \\
\left(T^{1}\right) \\
\left(\mathrm{ft}^{2} / \mathrm{d}\right)\end{array}$ & $\begin{array}{c}\text { Aquifer } \\
\text { thick- } \\
\text { ness } \\
\text { (b) } \\
\text { (feet) }\end{array}$ & $\begin{array}{l}\text { Hydrau- } \\
\text { lic } \\
\text { conduc- } \\
\text { tivity } \\
\text { (K) } \\
\text { (f/d) }\end{array}$ & $\begin{array}{l}\text { Strati- } \\
\text { graphic } \\
\text { unit }\end{array}$ \\
\hline \multirow[t]{2}{*}{$29-1060$} & \multirow{2}{*}{$\begin{array}{l}5 / 1 / 93- \\
5 / 30 / 93\end{array}$} & Low & 75 & 10.20 & 9.25 & 3,000 & 12,000 & 0.15 & 1,800 & 75 & 24 & \multirow[t]{2}{*}{ C } \\
\hline & & High & 82 & 3.20 & 2.25 & 3,000 & 43,000 & .20 & 8,600 & 75 & 110 & \\
\hline \multirow[t]{2}{*}{ 29-1059 } & \multirow{2}{*}{$\begin{array}{l}11 / 1 / 92- \\
11 / 30 / \\
92\end{array}$} & Low & 120 & 8.03 & 7.72 & 6,000 & 19,000 & .15 & 2,900 & 100 & 29 & \multirow[t]{2}{*}{ C } \\
\hline & & High & 126 & 2.03 & 1.72 & 6,000 & 81,000 & .20 & 16,000 & 100 & 160 & \\
\hline \multirow[t]{2}{*}{$29-486$} & \multirow[t]{2}{*}{$\begin{array}{l}10 / 1 / 84 \\
2 / 28 / 85\end{array}$} & Low & 115 & 11.80 & 9.80 & 8,000 & 32,000 & .15 & 4,800 & 200 & 24 & \multirow[t]{2}{*}{ C } \\
\hline & & High & 120 & 6.80 & 4.80 & 8,000 & 60,000 & .20 & 12,000 & 200 & 60 & \\
\hline \multirow[t]{2}{*}{$25-716$} & \multirow{2}{*}{$\begin{array}{l}11 / 1 / 92- \\
11 / 30 / \\
92\end{array}$} & Low & 95 & 20.29 & 20.00 & 4,000 & 3,100 & .15 & 470 & 50 & 9 & \multirow[t]{2}{*}{$\mathbf{K}$} \\
\hline & & High & 105 & 10.29 & 10.00 & 4,000 & 6,200 & .20 & 1,200 & 50 & 25 & \\
\hline
\end{tabular}

${ }^{1}$ See equation (1), p. 19.

The estimates are a general indication of the distribution of hydraulic characteristics, although their accuracy is limited by the underlying assumptions of the methodology. The greatest sources of error probably are the estimated elevation of the nearby stream reach from which starting and ending water levels were calculated and specific yield. To account for this uncertainty, a range of stream elevations and values of specific yield was used in calculations, resulting in a range of calculated hydraulic characteristics. The ranges are defined by the respective "low" and "high" estimates in table 2. Results show that the values of estimated horizontal hydraulic conductivity derived from recession analysis of wells in the Cohansey Sand outcrop area are higher than those derived from the recession analysis of the well open to the Kirkwood Formation.

As an additional test for the presence of a contrast in hydraulic conductivities, well-performance data for wells tapping either the Cohansey Sand or the Kirkwood Formation throughout the study area were analyzed and compared. An equation described by Walton (1970, p. 315) relating specific capacity to aquifer transmissivity was used to estimate aquifer hydraulic conductivity at 166 wells for which specific-capacity and other necessary data were available (fig. 9). 


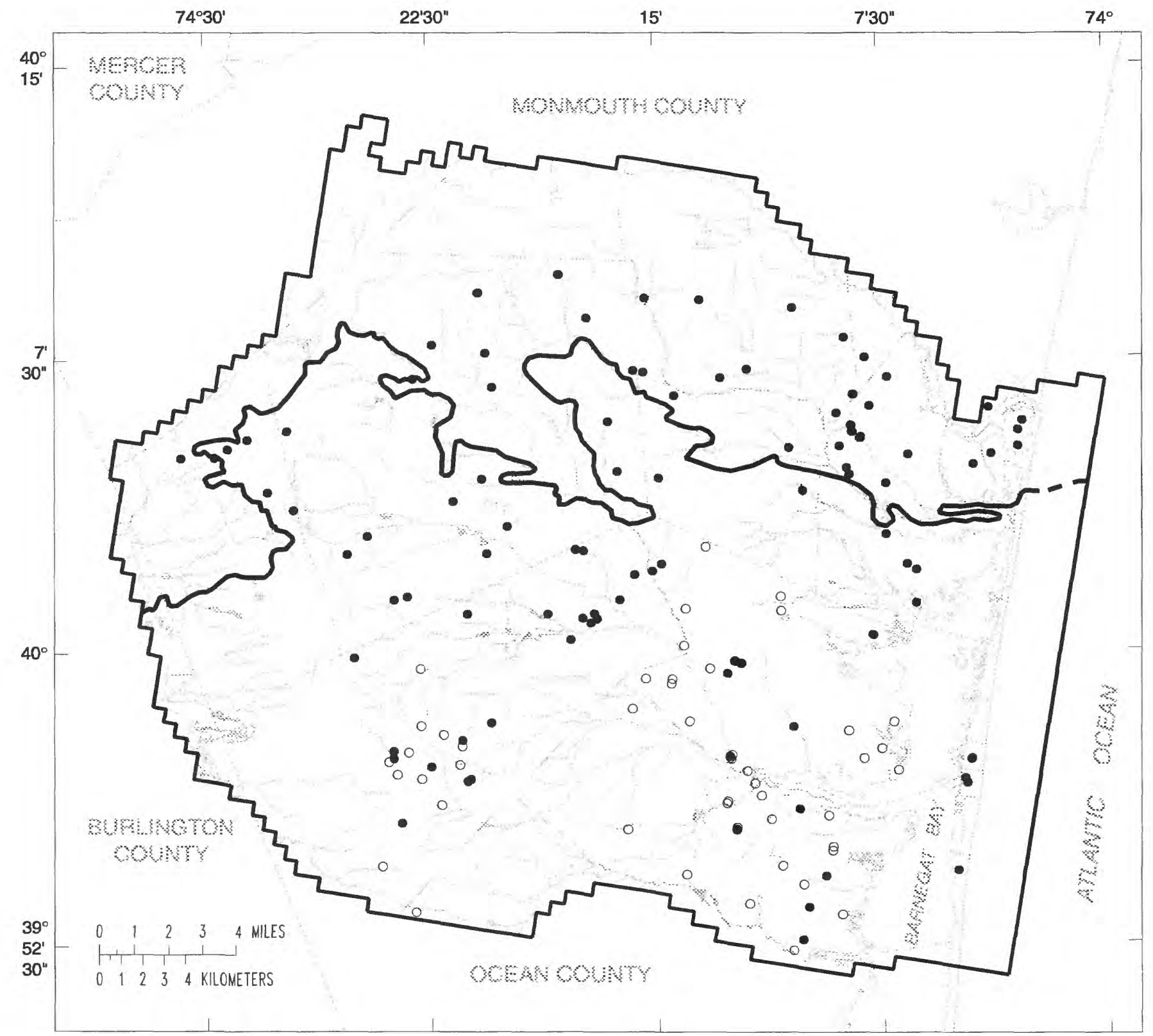

\section{EXPLANATION}

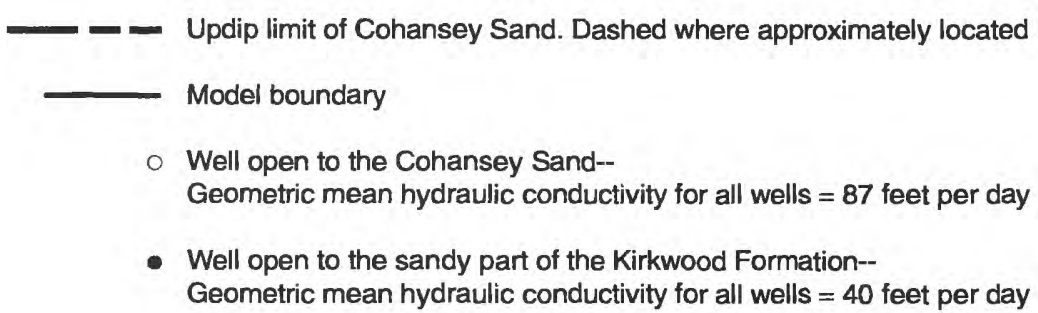

Figure 9. Locations of wells used to determine hydraulic conductivity from well-performance data, Toms River, Metedeconk River, and Kettle Creek Basins, New Jersey. 
Estimates of hydraulic conductivity from specific-capacity data are affected by a number of complicating factors and limiting assumptions of the methodology. As a result, the range of values of estimated hydraulic conductivity is large. The frequency distribution of estimated values of hydraulic conductivity for each unit roughly approximates a log-normal distribution. The geometric mean of hydraulic-conductivity estimates for wells tapping the Cohansey Sand was $87 \mathrm{ft} / \mathrm{d}$, whereas that for wells tapping the Kirkwood Formation was $40 \mathrm{ft} / \mathrm{d}$.

From the results of water-level-recession analyses, well-performance analyses, and other investigations, it is concluded that the hydraulic conductivity of the Cohansey Sand is higher than that of the Kirkwood Formation in the study area.

The upper part of the Kirkwood-Cohansey aquifer system is represented by model layer 1 as shown in figure 6. Horizontal hydraulic conductivity $\left(K_{h}\right)$ in layer 1 used in simulations of flow ranges from 20 to $100 \mathrm{ft} / \mathrm{d}$ (fig. 10). (The ranges of final calibrated values of all model parameters are summarized in table 3.) In areas where the upper part of the Kirkwood-Cohansey aquifer system contains only Cohansey Sand and younger sediments, a $K_{h}$ of $100 \mathrm{ft} / \mathrm{d}$ was used. The updip limit of this area was identified by estimating locations where the altitude of the bottom of the Cohansey Sand intersects the midpoint of the thickness of the entire aquifer system. In areas where the Kirkwood Formation crops out, $K_{h}$ is $20 \mathrm{ft} / \mathrm{d}$. Within the zone between these two areas, layer 1 represents a volume of the aquifer system that includes both Kirkwood and Cohansey sediments. This zone was divided into two subzones of intermediate values of $K_{h}$ to approximate a gradient of increasing $\mathrm{K}_{\mathrm{h}}$ downdip.

Table 3. Summary of model parameters, Kirkwood-Cohansey aquifer system, New Jersey

\begin{tabular}{llll}
\hline \multicolumn{1}{c}{ Model parameter } & \multicolumn{1}{c}{ Units } & \multicolumn{1}{c}{ Layer } & \multicolumn{1}{c}{ Range } \\
\hline $\begin{array}{l}\text { Horizontal hydraulic } \\
\text { conductivity }\end{array}$ & feet per day & 1 & $20-100$ \\
& & 2 & $20-100$ \\
& & 3 & 20 \\
$\begin{array}{l}\text { Specific yield } \\
\text { (unconfined) }\end{array}$ & dimensionless & 1 and 2 & $0.15-.20$ \\
$\begin{array}{l}\text { Storage coefficient } \\
\text { (confined) }\end{array}$ & dimensionless & 2 and 3 & .20 \\
$\begin{array}{l}\text { Vertical } \\
\text { leakance }\end{array}$ & feet per day per foot & between 1 and 2 & $1 \times 10^{-4}$ to \\
& & between 2 and Piney & $2 \times 10^{-7}$ to \\
& & Point aquifer & $1 \times 10^{-4}$ \\
& & between 2 and 3 & $1 \times 10^{-4}$ to \\
& & & $2 \times 10^{-1}$ \\
\hline
\end{tabular}

1 In simulations, when the head is below the top of the aquifer layer, specific yield is used; when the head is above the top of the aquifer layer, the storage coefficient is used (McDonald and Harbaugh, 1988, p. 5-39). 

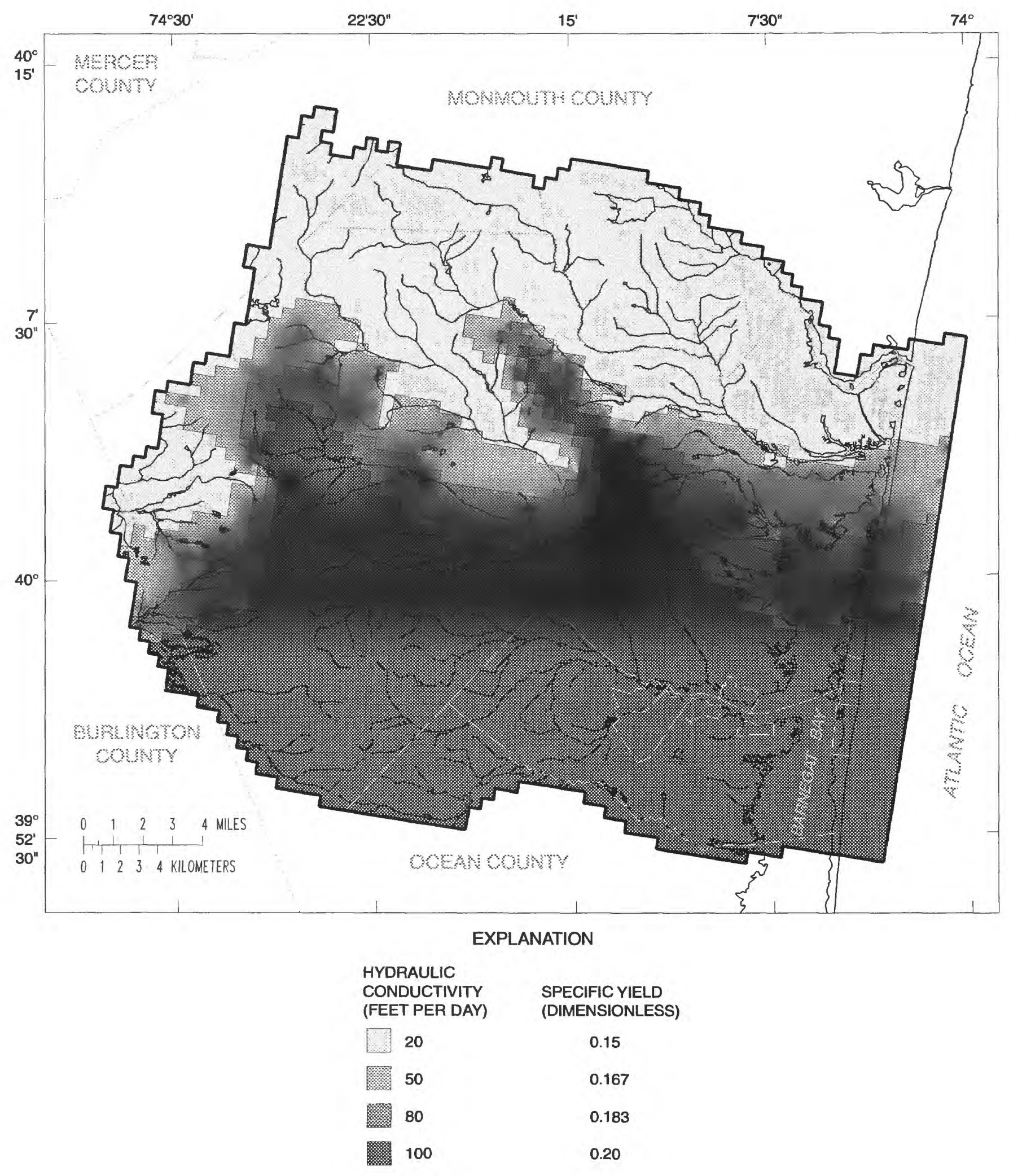

Model boundary, layer 1

Figure 10. Distribution of horizontal hydraulic conductivity and specific yield, model layer 1 , Toms River, Metedeconk River, and Kettle Creek Basins, New Jersey. 
The distribution of the unconfined storage coefficient of the Kirkwood-Cohansey aquifer system was represented in transient simulations in a manner similar to that used to represent $\mathrm{K}_{\mathrm{h}}$. In layer 1, the unconfined storage coefficient, or specific yield, was 0.2 in areas where only Cohansey Sand is represented, and 0.15 in areas where only Kirkwood Formation is represented. Intermediate values of specific yield were used in areas where layer 1 represents a composite of both units (fig. 10). In layers 2 and 3, the storage coefficient was 0.0003 in areas where the aquifer is confined, and the specific yield was 0.20 in areas where the aquifer is unconfined.

The hydraulic connection between model layers 1 and 2 is represented by leakance values. (The model computer program multiplies leakance values by cell area to obtain vertical conductance, which is used to calculate flow rates between layers.) In areas where no significant confining layers are present, leakance values were calculated from the vertical hydraulic conductivities and the thicknesses of the two interacting aquifers, according to the method described by McDonald and Harbaugh (1988, eqn. 51, p. 5-13). Vertical hydraulic conductivity of the Kirkwood-Cohansey aquifer system was calculated as the product of 0.01 and the $\mathrm{K}_{\mathrm{h}}$ to account for aquifer anisotropy. Anisotropy is highly scale-dependent and may be considerably different at other scales of evaluation. Borehole and water-quality data indicate that ground water in the deep part of the system may be confined or semiconfined. Substantial thicknesses of silt and clay (up to $104 \mathrm{ft}$ ) have been reported at various depths in geologists' and drillers' logs of boreholes drilled near the coast and on the barrier island. In coastal areas where thicknesses of silt and clay are substantial, a single leakance value was selected that is much lower than that used in other areas. The distribution of leakances between model layers 1 and 2 is shown in figure 11 .

The lower part of the Kirkwood-Cohansey aquifer system is represented by model layer 2 . The distribution of $\mathrm{K}_{\mathrm{h}}$ in layer 2 used in simulations of flow is shown in figure 11. Throughout most of model layer 2 , the value of $\mathrm{K}_{\mathrm{h}}$ used was $20 \mathrm{ft} / \mathrm{d}$, except near the coast and in offshore areas, where a value of $100 \mathrm{ft} / \mathrm{d}$ was used. The area where the higher value was used includes the locations of high-yield production wells that tap the lower part of the Kirkwood-Cohansey aquifer system in Seaside Heights, Ocean Gate, and Point Pleasant Beach Boroughs.

\section{Basal Kirkwood Formation Confining Unit}

The confining unit separating the Kirkwood-Cohansey aquifer system (model layer 2) from the underlying Vincentown aquifer (model layer 3 ) is represented by leakance values, which control the rate of flow between these two model layers. The distribution of vertical leakance between model layers 2 and 3 is shown at the top of figure 12. Leakances were determined from the thickness and estimated vertical hydraulic conductivity of the confining unit and from aquifer properties according to the method described by McDonald and Harbaugh (1988, eqn. 51, p. 513). The vertical hydraulic conductivity of the confining unit used in leakance calculations is $5.7 \mathrm{x}$ $10^{-3} \mathrm{ft} / \mathrm{d}$, as determined by Brown and Zapecza (1990) from laboratory tests of core samples collected from a borehole near the Manasquan Reservoir in Howell Township. The calculated values of leakance used in simulations are therefore controlled by the thickness of the confining unit in areas where it is present. In areas just downdip from the Vincentown aquifer outcrop where the confining unit is not present, the leakances used in simulations are controlled by the vertical hydraulic conductivities of the interacting aquifers and are much higher. 

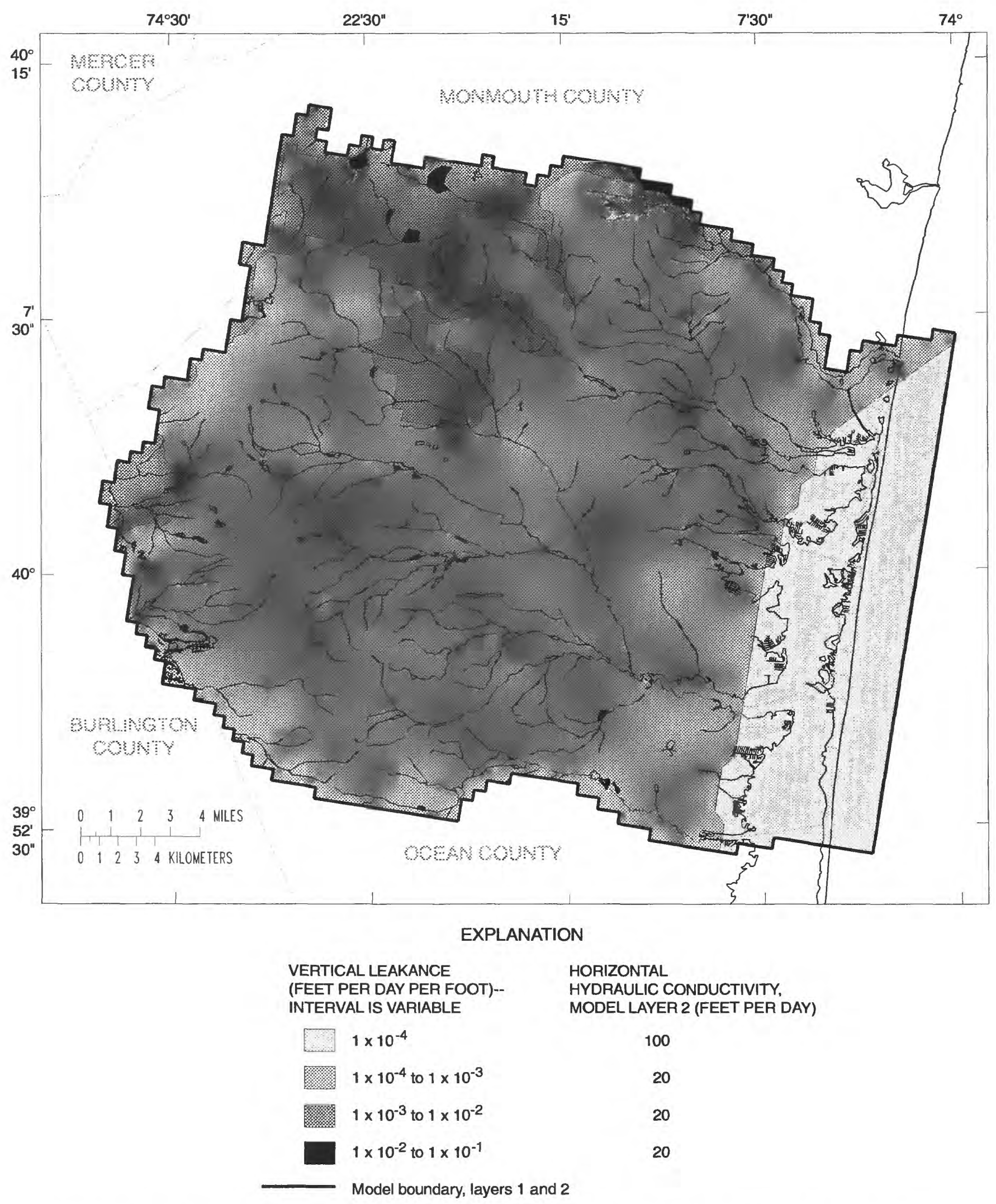

Figure 11. Distribution of vertical leakance between model layers 1 and 2 and distribution of horizontal hydraulic conductivity in model layer 2, Toms River, Metedeconk River, and Kettle Creek Basins, New Jersey. 


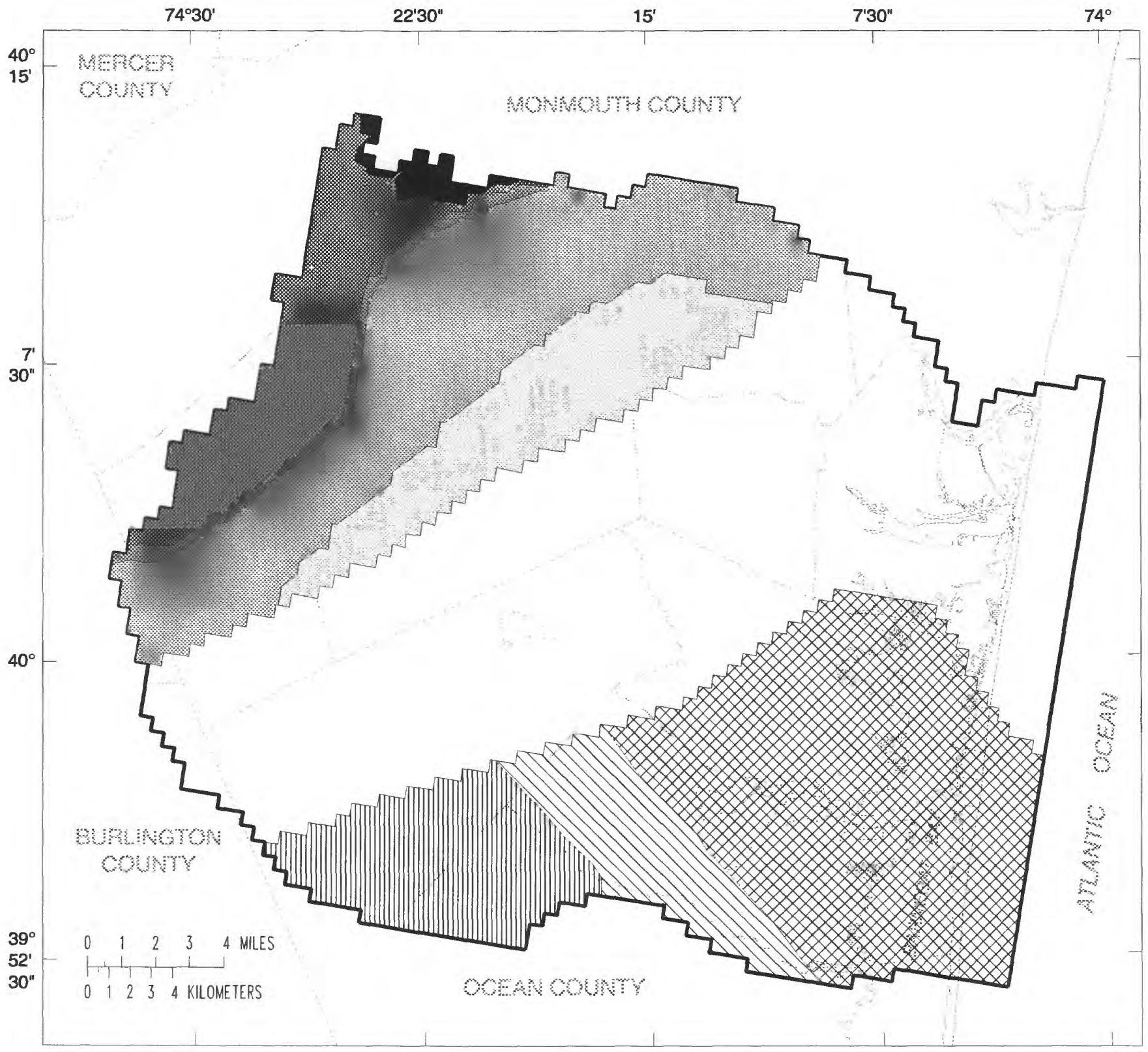

\section{EXPLANATION}

VERTICAL LEAKANCE (FEET PER DAY PER FOOT)--Interval is variable

Leakance between the
Kirkwood-Cohansey aquifer system (L2)
and the Piney Point aquifer (head-depend
flux boundary)
$2 \times 10^{-7}$ to $1 \times 10^{-6}$
$1 \times 10^{-6}$ to $1 \times 10^{-5}$
$1 \times 10^{-5}$ to $1 \times 10^{-4}$
$\begin{aligned} & \text { Area where Vincentown and } \\ & \text { Piney Point aquifers are } \\ & \text { absent }\end{aligned}$

Leakance between the

Kirkwood-Cohansey aquifer system (L2)

and the Vincentown aquifer (L3)

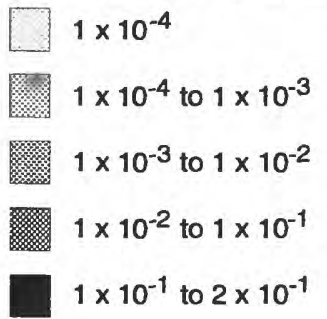

Model boundary, layer 2

Figure 12. Distribution of vertical leakance between model layer 2 and underlying aquifers, Toms River, Metedeconk River, and Kettle Creek Basins, New Jersey. 


\section{Vincentown Aquifer}

Data on the hydraulic characteristics of the Vincentown aquifer are limited. In a study of ground-water mounding beneath the Manasquan Reservoir, Koury and others (1989) estimated the $\mathrm{K}_{\mathrm{h}}$ of the Vincentown aquifer to be $14 \mathrm{ft} / \mathrm{d}$ from field and laboratory data and used this value to simulate ground-water flow in the aquifer over a $12-\mathrm{mi}^{2}$ area surrounding the reservoir. A laboratory analysis of sediments from Burlington County by Rush (1968) resulted in an estimated hydraulic conductivity of $21 \mathrm{ft} / \mathrm{d}$. For this study, a uniform value of $20 \mathrm{ft} / \mathrm{d}$ was used in simulations.

\section{Composite Confining Unit}

The composite confining unit between the Kirkwood-Cohansey aquifer system and the Piney Point aquifer is represented by boundary leakances (fig. 12), which were determined from leakances used in an update of the New Jersey Coastal Plain Regional Aquifer Simulation Analysis (RASA) model (D.A. Pope, U.S. Geological Survey, written commun., 1992). Vertical leakance values between model layer 2 and the Piney Point aquifer range from $2 \times 10^{-7}$ to $1 \times 10^{-4}(\mathrm{ft} / \mathrm{d}) / \mathrm{ft}$.

\section{Steady-State Calibration}

The model was calibrated by trial-and-error adjustment of input parameters and boundaries within reasonable ranges such that simulated bead and base-flow distributions matched reasonably well with those determined from field measurements. Model parameters adjusted through steady-state calibration include hydraulic conductivity, vertical leakance, stream stage, streambed conductance, boundary conductance, and boundary heads. The sensitivity of simulated heads and base flows to various model parameters and boundaries was tested and evaluated. Tests of model sensitivity provide a limited indication of model reliability. The following sections describe the calibration and sensitivity analysis of the steady-state-flow model.

The period 1980-89 was selected for steady-state calibration on the basis of several factors. The hydrologic system during that time was similar to the system in its current (1997) state. Also, the period is sufficiently long that average base flows for the period were not affected to any large extent by individual dry or wet periods. Most of the data needed for the analysis of this period were compiled and are reported by Watt and others (1994).

\section{Water Levels}

Simulated water levels were compared with water levels measured in wells and surfacewater bodies during a synoptic water-level survey in October-November 1987. Water levels in the Crammer observation well (29-486) (within the study-area boundary) and the Lebanon State Forest observation well (5-689) (just beyond the study-area boundary)(see fig. 2 for well locations) during October-November 1987 were within 0.5 and $1.3 \mathrm{ft}$ of their respective averages for 1980-89. Water levels throughout the study area were assumed to have been near their respective 1980-89 averages during October-November 1987. 
The locations of wells used to calibrate the steady-state model are shown in figure 13. Water-level contours interpreted from measured water levels and simulated water-level contours are shown in figure 14. Simulated water levels correspond closely with water levels interpreted from field data.

The model reproduces the higher hydraulic gradient in the Metedeconk than in the Toms River drainage area. The gradient in the Metedeconk River drainage area is higher because the permeability of aquifer materials is lower than that in most of the Toms River drainage area. Differences between measured and simulated water levels (water-level residuals) tend to be greater at well locations where gradients are relatively steep than at well locations where they are relatively shallow. Simulated water levels also tend to be lower than interpreted water levels in some areas between stream channels. These minor discrepancies are considered to be acceptable consequences of the scale of horizontal and vertical discretization.

Simulated and observed water levels (table 4) were compared at 80 well locations (fig. 13). Statistics summarizing the differences between simulated and observed water levels are listed in table 5. Simulated water levels at well locations were calculated by linear interpolation between the simulated water levels at the three nearest model nodes. The mean difference between simulated and observed layer-1 water levels (mean water-level residual) is $-0.5 \mathrm{ft}$, an indication that any overall bias in simulated water levels is small--that is, the model does not tend to over- or underpredict water levels. The mean absolute water-level residual is $4.5 \mathrm{ft}$ and the rootmean-square error is $6.3 \mathrm{ft}$. These errors are small in comparison with the range of observed water levels (4-172 $\mathrm{ft}$ ) in the study area. These statistics are indications of the close match between simulated and observed water levels. A similarly close match was achieved for model layer 2.

Table 5. Statistics for water-level residuals, model layers 1 and 2, Toms River, Metedeconk River and Kettle Creek Basins, New Jersey

\begin{tabular}{ccccc}
\hline Model layer & $\begin{array}{c}\text { Number of } \\
\text { wells }\end{array}$ & $\begin{array}{c}\text { Mean water-level } \\
\text { difference } \\
\text { (feet) }\end{array}$ & $\begin{array}{c}\text { Mean absolute water- } \\
\text { level difference } \\
\text { (feet) }\end{array}$ & $\begin{array}{c}\text { Root-mean-square } \\
\text { error } \\
\text { (feet) }\end{array}$ \\
\hline 1 & 63 & -0.5 & 4.5 & 6.3 \\
2 & 17 & -1.8 & 5.3 & 6.3 \\
1 and 2 & 80 & -.8 & 4.7 & 6.3 \\
\hline
\end{tabular}

Many of the larger water-level residuals can be explained partly by the representation of streams in the ground-water-flow model. The largest positive residual (simulated water level is higher than observed) $(20.3 \mathrm{ft}$ ) resulted in an area where a small unmapped tributary to the South Branch Metedeconk River drains part of the aquifer. Because the stream was not represented in the model, simulated water levels are higher than interpreted water levels in this area. In areas where the aquifer is drained by other unmapped tributaries, simulated water levels probably also are slightly overestimated. Many of the larger negative water-level residuals (simulated water levels are lower than observed) resulted in areas where wells are in model cells that contain a stream reach. These differences are commonly a consequence of the scale of horizontal discretization; the simulated water level in the cell is commonly controlled by and is similar to the boundary water level representing stream stage, so that the simulated water level at a nearby well is slightly underestimated. If the model were discretized more finely, the water levels at wells near streams could be reproduced more accurately. 


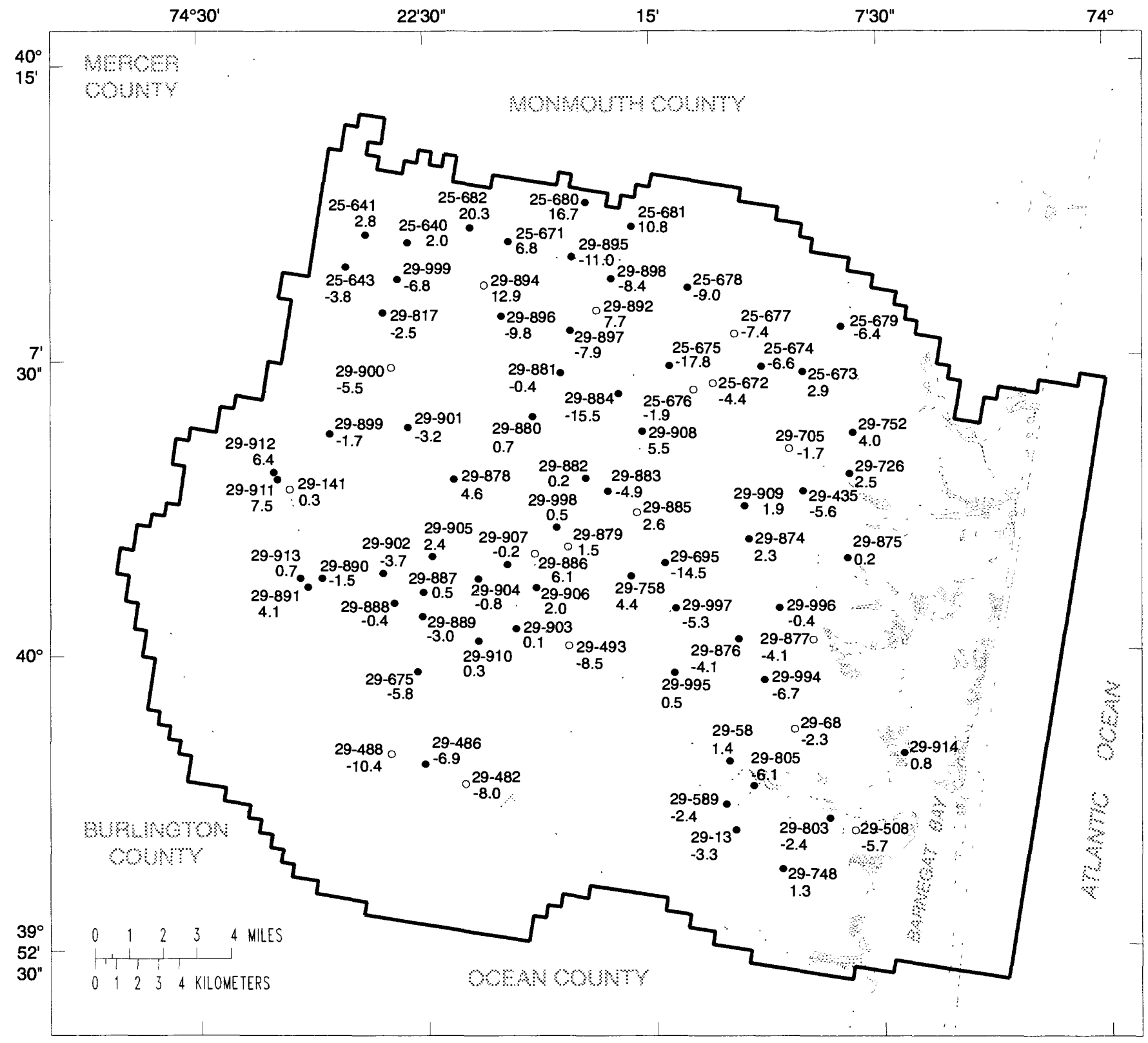

\section{EXPLANATION}

Model boundary, layers 1 and 2

29-900 ${ }^{\circ}$ WELL LOCATION--Well open to upper part of the Kirkwood-Cohansey aquifer system. -5.5 Top number is well identifier; bottom number is simulated water level in model layer 1 minus measured water level

29-13 WELL LOCATION--Well open to lower part of the Kirkwood-Cohansey aquifer system.

-3.3 Top number is well identifier; bottom number is simulated water level in model layer 2 minus measured water level

Figure 13. Locations of wells used in steady-state-model calibration, Toms River, Metedeconk River, and Kettle Creek Basins, New Jersey. 


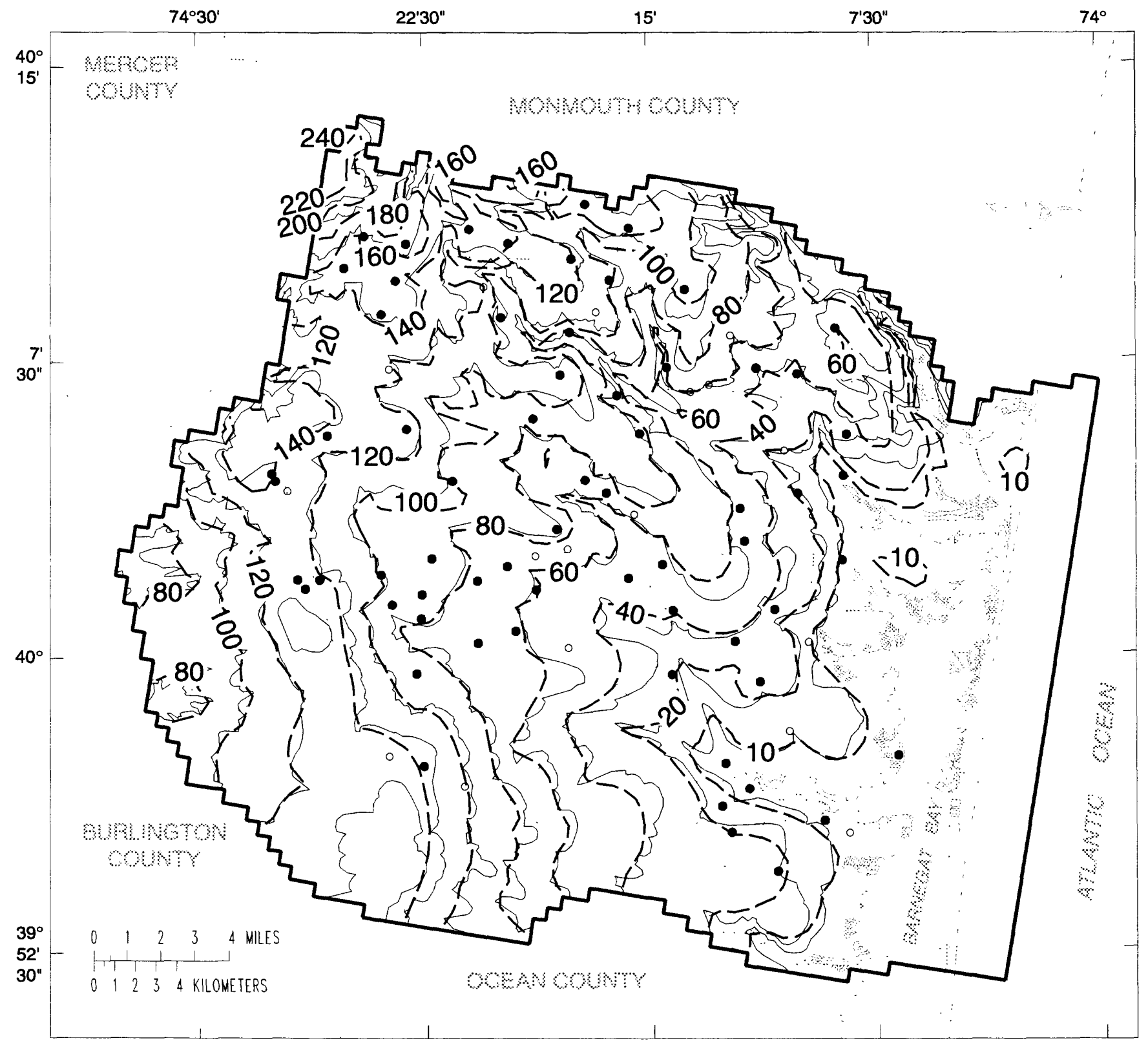

EXPLANATION

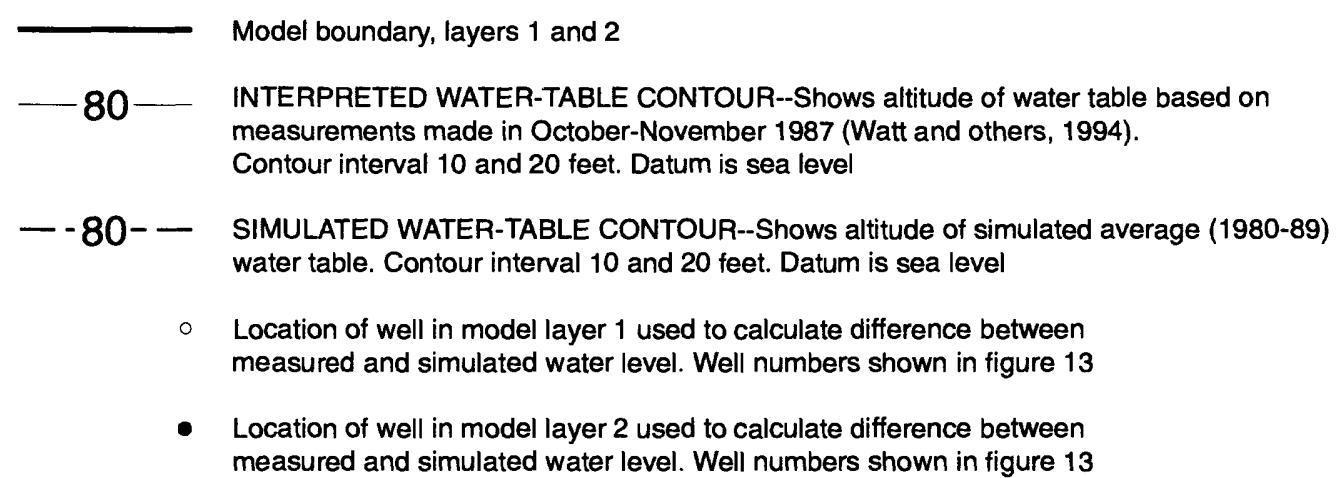

Figure 14. Observed and simulated water-table altitudes, Toms River, Metedeconk River, and Kettle Creek Basins, New Jersey. 


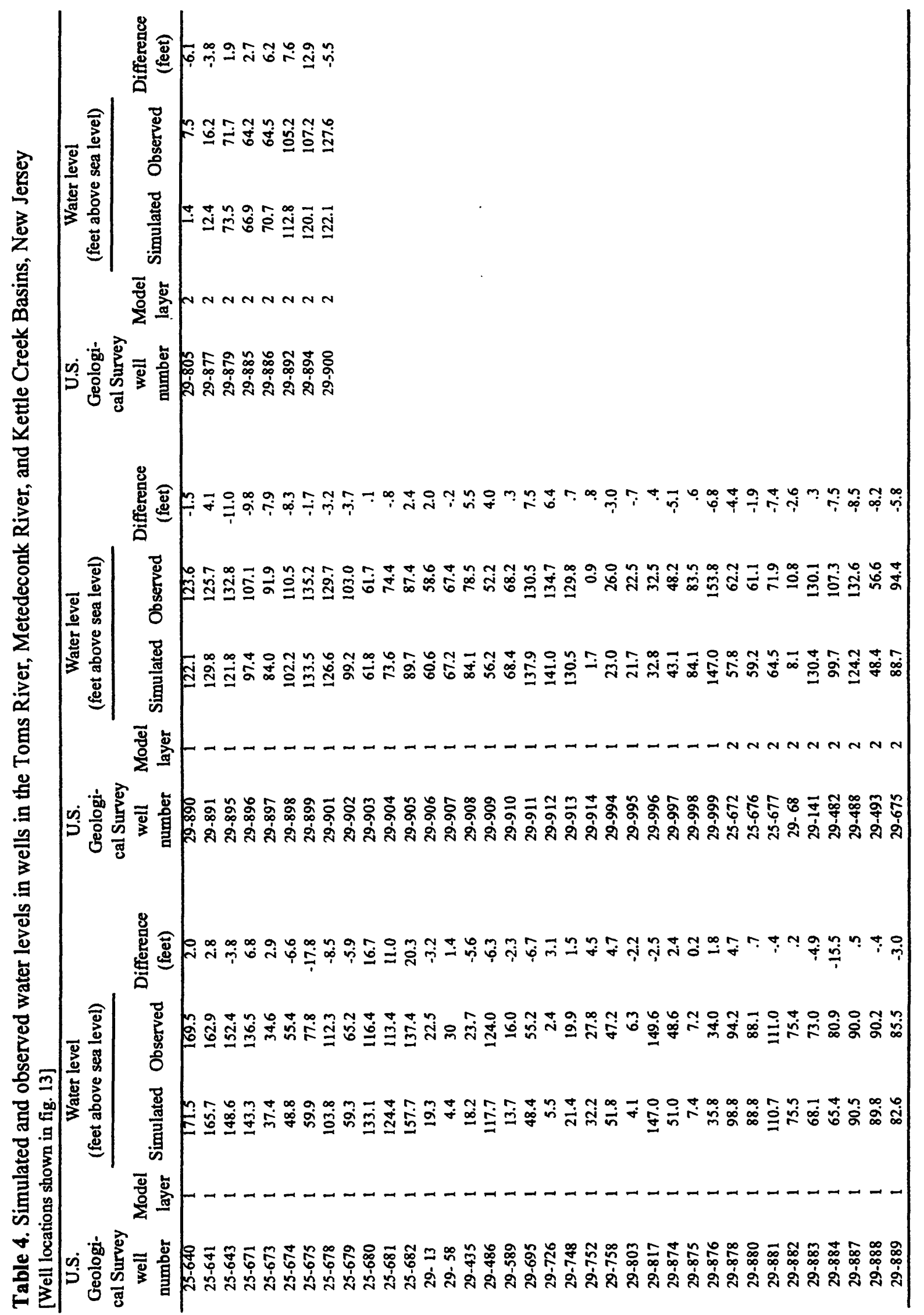


Water-level residuals were analyzed to determine whether any distributional biases are evident. Distributional biases can indicate inappropriate boundaries or values of hydraulic parameters. Simulated and observed water levels are compared graphically in figure 15 to show the relation between water-level residuals and water-table altitude. The good fit between the data points and the line of equality is an indication that the model reproduced observed water levels with similar accuracy at different water-table altitudes. The areal distribution of water-level residuals is shown in figure 13. The generally random spatial distribution of water-level residuals is an indication that the model simulates water levels with similar accuracy in different geographic areas. This analysis indicates that distributional biases are negligible.

\section{Base Flow}

An objective of model calibration was to achieve a reasonable match between the simulated distribution of base flow and the distribution of base flow at all streamflow-measurement stations for which estimates of average $1980-89$ base flow were available. Ten streamflowmeasurement stations were available for this comparison; their locations are shown in figure 2 , and estimates of average 1980-89 base flow at each station are listed in table 6.

Continuous streamflow data for 1980-89 are available for two of the stations--Toms River near Toms River, N.J. (01408500), and North Branch Metedeconk River near Lakewood, N.J. (01408120). Reliable estimates of average $1980-89$ base flow at these two stations were obtained by hydrograph-separation analysis, as discussed by Watt and others (1994, sheet 3 ). These two base-flow estimates are considered primary calibration targets, and matching simulated base flows with these estimates was a high priority.

Streamflow data for the other eight low-flow partial-record stations are limited to a few measurements each, collected over different time periods. Average 1980-89 base-flow values for these stations were estimated by low-flow-correlation analysis and are listed in table 6 . The value of average 1980-89 base flow for Toms River near Toms River $\left(163.2 \mathrm{ft}^{3} / \mathrm{s}\right)$ was substituted as index-station flow (QI) into the respective correlation equations determined by Watt and others $(1994$, sheet 3$)$ for six of these sites. Correlation equations for the remaining two sites $(01408600$, 01408630) were developed from analysis of recent streamflow data, and similarly used to estimate average 1980-89 base flow as listed in table 6. Correlation equations for these two sites were determined by using the Maintenance of Variance Extension, Type 1 (MOVE.1) method used by Watt and others (1994). Estimates of base flow for the eight partial-record sites are considered less reliable than those for the two continuous-streamflow-gaging stations. Watt and others (1994, sheet 3 ) discuss the uncertainty of flows predicted by using this methodology, and determined standard errors of estimation (indicators of reliability of estimates) ranging from 2 to 8 percent for estimates of 7-day 10-year low-flow discharge for six of these sites (Watt and others, 1994, table 3-2). Because of this statistical uncertainty, base-flow estimates for partial-record sites were considered secondary targets in model calibration. Larger discrepancies between simulated and estimated base flow (up to 20 percent for small streams) at partial-record stations were considered acceptable.

Table 6 also lists simulated base flow at each station and the differences between simulated and estimated base flow. Simulated base flows for Toms River near Toms River, N.J. (01408500), and for North Branch Metedeconk River near Lakewood, N.J. (01408100), are each within 1 percent of estimated base flows. Base flow at these two stations accounts for about 67 percent of the combined estimated base flows of the Toms and Metedeconk Rivers at their respec- 


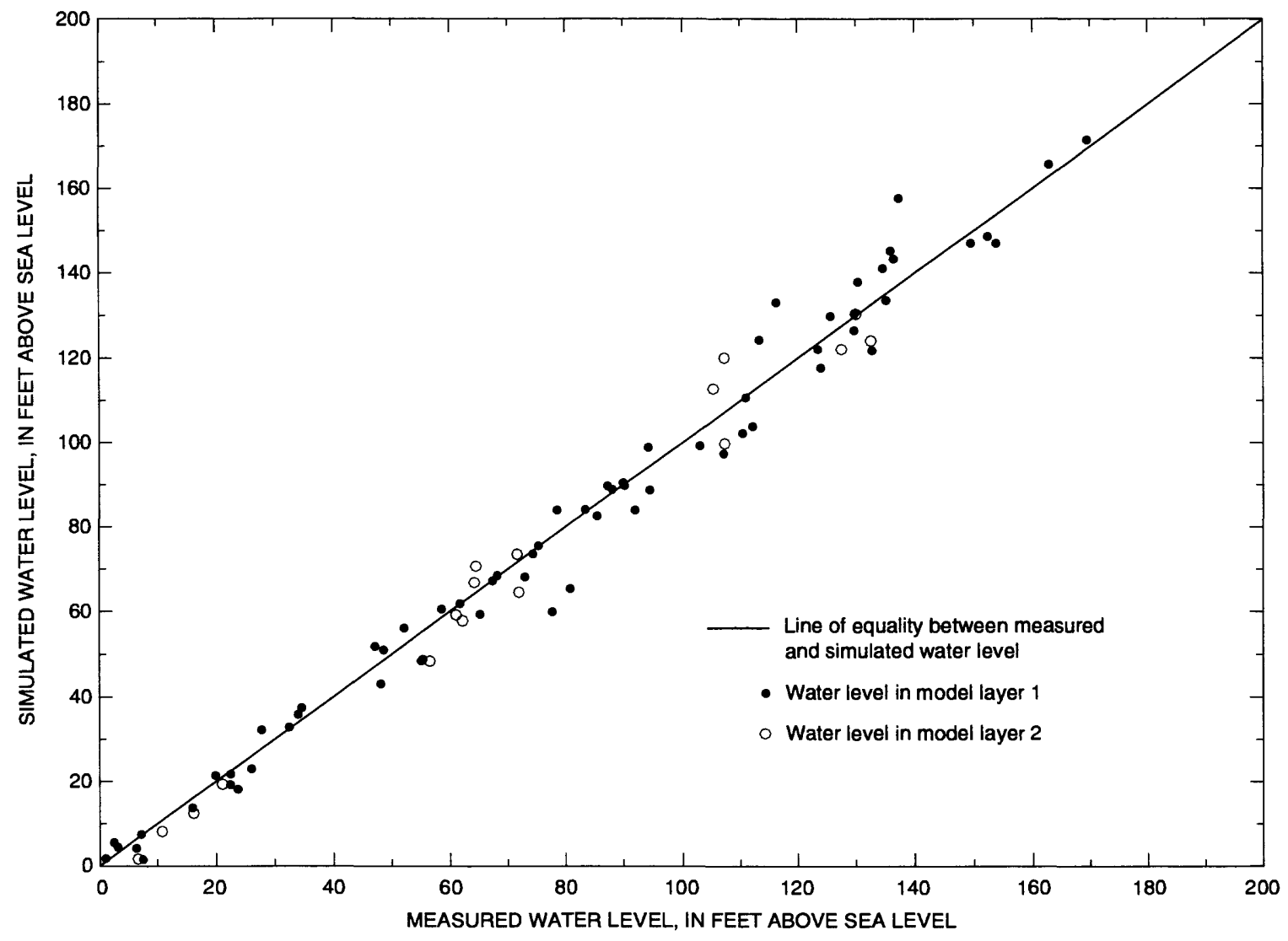

Figure 15. Relation between measured (October-November 1987) and simulated average (1980-89) water levels, model layers 1 and 2, Toms River, Metedeconk River, and Kettle Creek Basins, New Jersey. 
Table 6. Correlation equations used to estimate average 1980-89 base flow at 8 low-flow partial-record stations; estimated and simulated base flows at 10 streamflow-gaging stations; and differences between estimated and simulated base flows, Toms River, Metedeconk River, and Kettle Creek Basins, New Jersey

[ $\mathrm{ft}^{3} / \mathrm{s}$, cubic feet per second; $\mathrm{QP} \mathrm{R}_{\mathrm{R}}$, predicted discharge; $\mathrm{QI}$, index-station discharge; --, continuous-record streamflow-gagingstation base flow estimated by using hydrograph-separation technique (Sloto and Crouse, 1996).]

\begin{tabular}{|c|c|c|c|c|c|c|c|}
\hline $\begin{array}{l}\text { U.S. } \\
\text { Geological } \\
\text { Survey } \\
\text { streamflow- } \\
\text { gaging- } \\
\text { station } \\
\text { number }\end{array}$ & $\begin{array}{l}\text { Streamflow-gaging- } \\
\text { station } \\
\text { name }\end{array}$ & $\begin{array}{l}\text { Drainage } \\
\text { area } \\
\text { (square } \\
\text { miles) }\end{array}$ & $\begin{array}{l}\text { Correlation equation } \\
\text { (low-flow partial- } \\
\text { record stations only) }\end{array}$ & $\begin{array}{c}\text { Estimated } \\
\text { average } \\
1980-89 \\
\text { base flow } \\
\left(\mathrm{ft}^{3} / \mathrm{s}\right)\end{array}$ & $\begin{array}{c}\text { Simulated } \\
\text { average } \\
1980-89 \\
\text { base flow } \\
\left(\mathrm{ft}^{3} / \mathrm{s}\right)\end{array}$ & $\begin{array}{c}\text { Simulated } \\
\text { minus } \\
\text { estimated } \\
\text { base flow } \\
\left(\mathrm{ft}^{3} / \mathrm{s}\right)\end{array}$ & $\begin{array}{c}\text { Simulated } \\
\text { minus } \\
\text { estimated } \\
\text { base flow } \\
\text { (percent } \\
\text { of } \\
\text { estimated } \\
\text { average } \\
\text { base flow) }\end{array}$ \\
\hline 01408100 & $\begin{array}{l}\text { North Branch Mete- } \\
\text { deconk River at } \\
\text { Lakewood, N.J. }\end{array}$ & 19.4 & $\begin{array}{l}\mathrm{QP}_{\mathrm{R}}=0.07125 \mathrm{QI} \\
(1.1075)\end{array}$ & 20.1 & 22.8 & 2.7 & 13.4 \\
\hline 01408120 & $\begin{array}{l}\text { North Branch Mete- } \\
\text { deconk River near } \\
\text { Lakewood, N.J. }\end{array}$ & 34.9 & -- & 40.6 & 40.9 & .3 & .7 \\
\hline 01408140 & $\begin{array}{l}\text { South Branch Mete- } \\
\text { deconk River at } \\
\text { Lakewood, N.J. }\end{array}$ & 26.0 & $\mathrm{QP}_{\mathrm{R}}=.17072 \mathrm{QI}^{(1.06)}$ & 37.8 & 35.4 & -2.4 & -6.3 \\
\hline 01408300 & $\begin{array}{l}\text { Toms River at } \\
\text { Whitesville, N.J. }\end{array}$ & 45.2 & $\begin{array}{l}\mathrm{QP}_{\mathrm{R}}=.26249 \mathrm{Ql} \\
(1.0173)\end{array}$ & 46.8 & 54.1 & 6.3 & 13.5 \\
\hline 01408440 & $\begin{array}{l}\text { Union Branch at } \\
\text { Lakehurst, N.J. }\end{array}$ & 19.0 & $\underset{(0.9633)}{\mathrm{QP}_{\mathrm{R}}=.24391 \mathrm{QI}}$ & 33.0 & 34.5 & 1.5 & 4.5 \\
\hline 01408460 & $\begin{array}{l}\text { Manapaqua Brook } \\
\text { at Lakehurst, N.J. }\end{array}$ & 6.3 & $\begin{array}{l}\mathrm{QP}_{\mathrm{R}}=.00977 \mathrm{QI} \\
(1.2579)\end{array}$ & 5.9 & 7.1 & 1.2 & 20.3 \\
\hline 01408490 & $\begin{array}{l}\text { Ridgeway Branch, } \\
\text { near Lakehurst, N.J. }\end{array}$ & 28.2 & $\underset{(1.4751)}{\mathrm{QP}_{\mathrm{R}}=.01608 \mathrm{QI}}$ & 29.5 & 34.8 & 5.3 & 18.0 \\
\hline 01408500 & $\begin{array}{l}\text { Toms River near } \\
\text { Toms River, N.J. }\end{array}$ & 123 & -- & 163.2 & 162.5 & -.7 & -.4 \\
\hline 01408600 & Wrangel Brook & 19.5 & $\begin{array}{l}\mathrm{QP}_{\mathrm{R}}=1.44418 \mathrm{QI} \\
(0.61541)\end{array}$ & 33.2 & 30.9 & -2.3 & -6.9 \\
\hline 01408630 & Davenport Branch & 12.1 & $\begin{array}{l}\mathrm{QP}_{\mathrm{R}}=.61457 \mathrm{QI} \\
(0.6444)\end{array}$ & 16.4 & 14.2 & -2.2 & -13.4 \\
\hline
\end{tabular}

tive heads of tide. Therefore, the close match between estimated and simulated base flow at these two locations demonstrates that the model accurately accounts for most of the base flow to these rivers. (In this report, "flow of the Toms River" refers to flow above the confluence with Jakes Branch, and "flow of the Metedeconk River" refers to flow at the ungaged head of tide.) 
Among partial-record stations, the largest difference between simulated and estimated base flow (20.3 percent) is that for Manapaqua Branch, a small tributary to the Toms River. Simulated base flow is $1.2 \mathrm{ft}^{3} / \mathrm{s}$ higher than estimated base flow, a difference considered acceptable at the regional scale of the model. The other high residual (18.0 percent), for Ridgeway Branch, may be partly the result of underestimation of the rate of ground-water ET from wetland areas. A higher rate of ground-water ET from wetlands than the $10.2 \mathrm{in} / \mathrm{yr}$ assumed in simulations would result in a lower average base flow, but it also would result in a larger difference between simulated and estimated base flow at other locations. Alternatively, the Ridgeway Branch subbasin may receive less recharge in wetland areas than was simulated. Saturated conditions near land surface in wetlands can increase rates of direct runoff or rejected recharge that would otherwise infiltrate the land surface. An analysis of the few available measurements of Ridgeway Branch streamflow indicates that historical flows during summer bave been particularly low in relation to those in other streams in the study area. Ground-water ET, therefore, appears to be an important component of the ground-water budget in this subbasin.

\section{Sensitivity Analysis}

The results of the steady-state-model calibration demonstrate that the model, with its particular combination of values of hydraulic parameters, boundary conditions, and hydrogeologic-unit geometries, reproduces historical water-level and base-flow distributions in the study area reasonably accurately. Alternative models that use different combinations of parameter values and geometries could similarly reproduce water levels and base flows with reasonable accuracy-in other words, the problem of model calibration does not have a unique solution. Simulation results can be evaluated by using the results of sensitivity analyses, through which the calibrated-model response to changes in values of various model parameters and boundary conditions is tested. The results of this evaluation provide information on the hydrologic controls on the flow system and a limited indication of model reliability. The results can also be used to guide future data-collection activities for the purpose of improving the model calibration.

Calibrated values of hydraulic conductivity, recharge, ground-water ET, leakance, streambed conductance, and stream-boundary stage were systematically changed independently within a plausible range. The model's sensitivity to reduction in recharge in urban areas also was evaluated. The magnitude of change in simulated water levels or base flow resulting from a change in a parameter's value is a measure of the sensitivity of the model solution to that particular parameter. If the solution is highly sensitive to a particular parameter, then the model can be useful in estimating the value of the parameter. High sensitivity does not guarantee high accuracy of parameter estimates, however. If the solution is insensitive to the parameter, then the model is not useful in estimating the parameter.

Hydraulic gradients are highly sensitive to changes in horizontal hydraulic conductivity $\left(\mathrm{K}_{\mathrm{h}}\right)$. Simulated transverse head profiles along model column 36 resulting from three simulations in which proportional but different distributions of $\mathrm{K}_{\mathrm{h}}$ were used for model layer 1 are shown in figure 16. All other model inputs remained identical to calibrated values. When $K_{h}$ is increased by a factor of two, hydraulic gradients are lower (the profile is flatter). If values of $\mathrm{K}_{\mathrm{h}}$ are decreased, gradients are steeper and relief in the water-table profile is greater. Sensitivity is greatest in areas between stream boundaries. Simulated heads near streams are relatively insensitive to $K_{h}$ because they are tightly controlled by boundaries representing stream stage. 


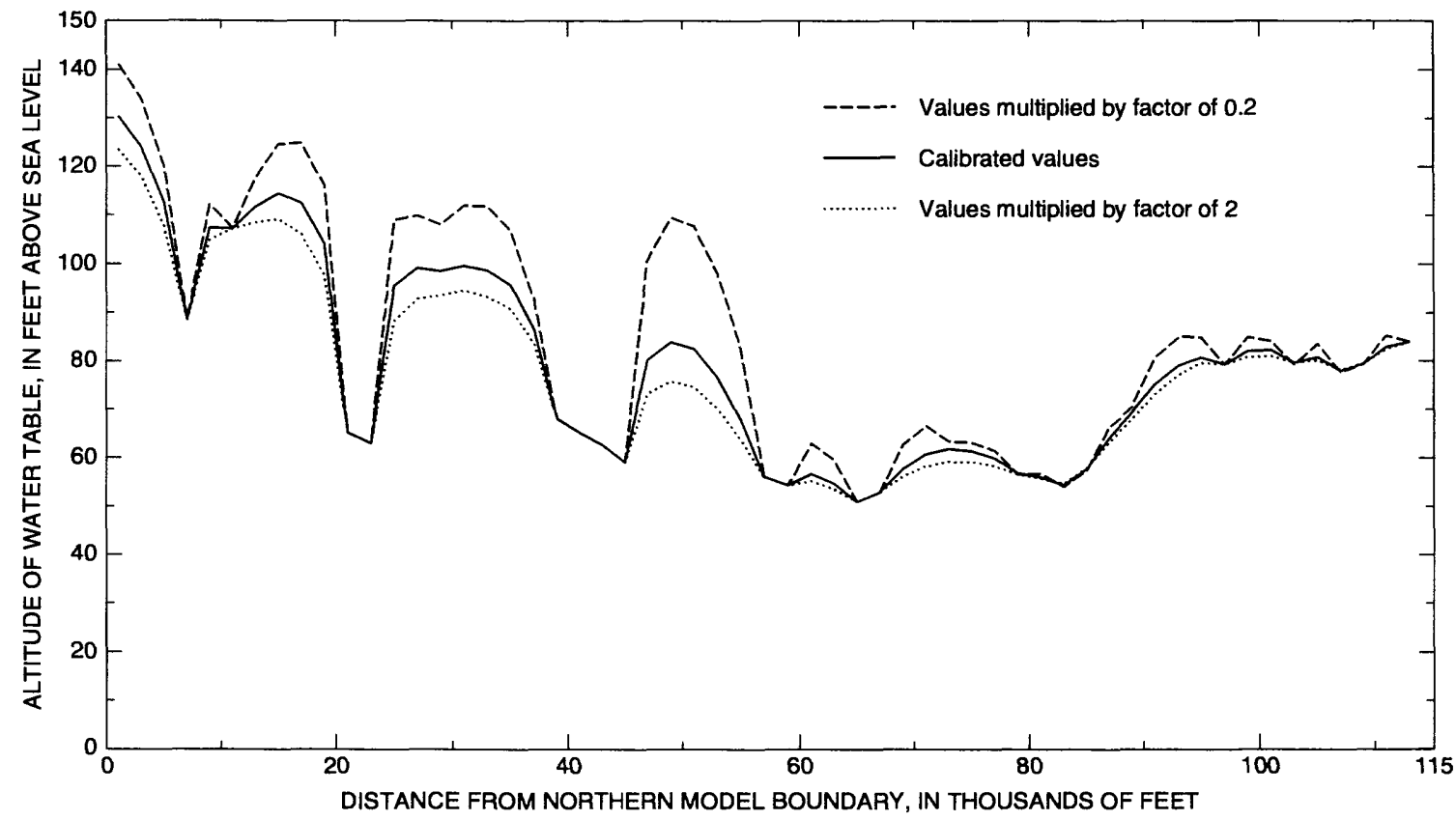

Figure 16. Transverse water-table profiles along model column 36 simulated by using calibrated values of layer 1 horizontal hydraulic conductivity and values of layer 1 horizontal hydraulic conductivity multiplied by factors of 0.2 and 2, Toms River, Metedeconk River, and Kettle Creek Basins, New Jersey. (Location of model column 36 shown in fig. 7) 
The effect on water levels of increasing recharge proportionately over the entire model area is opposite to that of increasing $\mathrm{K}_{\mathrm{h}}$. An increase in recharge increases hydraulic gradients, and a decrease in recharge decreases hydraulic gradients. The opposite effect of increases in the values of these two parameters illustrates the nonuniqueness of the calibration. Many possible simulations in which higher rates of recharge were used in conjunction with higher values of $K_{h}$ would result in water-table profiles similar to those simulated with the calibrated model. Simulations in which combinations of lower rates of recharge and lower values of $K_{h}$ were used would likewise result in similar profiles.

The sensitivity of simulated base flows to various model parameters was evaluated extensively. Results of base-flow-sensitivity analyses for several stream reaches are summarized in table 7. Base flow is highly sensitive to recharge rate. In contrast, the base flow of streams draining large areas, such as Toms River near Toms River, N.J. (01408500), is relatively insensitive to $K_{h}$ (table 7, simulations 1-4). Although different combinations of recharge and $K_{h}$ could result in reasonable head distributions, they would result in a larger discrepancy between simulated and observed base flow.

Base flow of the Davenport Branch, tributary to the Toms River, is highly sensitive to $K_{h}$ as well as to recharge (table 7 , simulations $1-4$ ). Sensitivity to $K_{h}$ in this part of the study area is a consequence of high headwater-channel elevation in relation to the elevation of nearby stream channels; surrounding streams capture much of the recharge that enters the uppermost part of the Davenport Branch surface-drainage area. If $K_{h}$ is increased, simulated heads are below headwater-channel elevations, and more of the ground-water flow near these headwaters is lost to surrounding streams. If $K_{h}$ is decreased, heads rise above headwater channels that otherwise would be dry, so that the Davenport Branch captures more of the recharge. Therefore, from a modeling standpoint, neither recharge nor $K_{h}$ is estimated as reliably within the Davenport Branch drainage area as they are in other areas. Additional water-level measurements in the uppermost part of the Davenport Branch surface-drainage area would provide the control needed to improve estimates of recharge and $\mathrm{K}_{\mathrm{h}}$ in this area.

The sensitivity of simulated base flows to reduction in recharge in urban areas was evaluated in a similar way. Recharge in urban areas was decreased an additional 20 percent and increased 25 percent from values used in the calibrated model, resulting in changes in base flow that ranged from -2 to $2 \mathrm{ft}^{3} / \mathrm{s}$, respectively (table 7 , simulations 5 and 6 ). On a percentage basis, the base flows of small tributary streams draining partly urban areas were most affected.

The effect of changes in rates of ground-water ET on base flow also was investigated (table 7, simulation 7). An increase in the rate of ground-water ET resulted in a decrease in the base flow of streams draining areas that include wetlands, whereas a decrease in the rate of ground-water ET had the opposite effect. Because a large percentage of the drainage area of the Ridgeway Branch tributary to the Toms River is wetlands, the assumed rate of ground-water ET has a substantial effect on the simulated base flow of that stream. Additionally, because the drainage area of the South Branch Metedeconk River includes a smaller percentage of wetlands, the simulated base flow of that stream is less sensitive to rates of ground-water ET. By including ground-water ET in simulations, a closer match between simulated and observed base flows was achieved than otherwise would have been possible. 
Table 7. Results of base-flow-sensitivity analyses in the Toms River, Metedeconk River, and Kettle Creek Basins, New Jersey

$\left[\mathrm{ft}^{3} / \mathrm{s}\right.$, cubic feet per second]

\begin{tabular}{|c|c|c|c|}
\hline $\begin{array}{l}\text { Simulation } \\
\text { number }\end{array}$ & $\begin{array}{c}\text { Change made to calibrated } \\
\text { model }\end{array}$ & Stream reach & Resulting change in base flow \\
\hline \multirow[t]{2}{*}{1} & $\begin{array}{l}\text { 100-percent increase in } \\
\text { hydraulic conductivity, layer } 1\end{array}$ & $\begin{array}{l}\text { Davenport Branch, tributary to } \\
\text { the Toms River }\end{array}$ & $\begin{array}{l}\text { Reduce base flow } 5.1 \mathrm{ft}^{3} / \mathrm{s} \\
\text { (36 percent) }\end{array}$ \\
\hline & & $\begin{array}{l}\text { Toms River near Toms River, } \\
\text { N.J. }\end{array}$ & $\begin{array}{l}\text { Reduce base flow } 4.0 \mathrm{ft}^{3} / \mathrm{s} \\
\text { ( } 2 \text { percent) }\end{array}$ \\
\hline \multirow[t]{2}{*}{2} & $\begin{array}{l}\text { 80-percent decrease in hydrau- } \\
\text { lic conductivity, layer } 1\end{array}$ & $\begin{array}{l}\text { Davenport Branch, tributary to } \\
\text { the Toms River }\end{array}$ & $\begin{array}{l}\text { Increase base flow } 3.1 \mathrm{ft}^{3} / \mathrm{s} \\
\text { ( } 22 \text { percent) }\end{array}$ \\
\hline & & $\begin{array}{l}\text { Toms River near Toms River, } \\
\text { N.J. }\end{array}$ & $\begin{array}{l}\text { Increase base flow } 0.2 \mathrm{ft}^{3} / \mathrm{s} \\
(0.3 \text { percent) }\end{array}$ \\
\hline \multirow[t]{2}{*}{3} & $\begin{array}{l}\text { 20-percent increase in } \\
\text { recharge }\end{array}$ & $\begin{array}{l}\text { Davenport Branch, tributary to } \\
\text { the Toms River }\end{array}$ & $\begin{array}{l}\text { Increase base flow } 4.6 \mathrm{ft}^{3} / \mathrm{s} \\
\text { ( } 32 \text { percent) }\end{array}$ \\
\hline & & $\begin{array}{l}\text { Toms River near Toms River, } \\
\text { N.J. }\end{array}$ & $\begin{array}{l}\text { Increase base flow } 37.8 \mathrm{ft}^{3} / \mathrm{s} \\
\text { ( } 23 \text { percent) }\end{array}$ \\
\hline \multirow[t]{2}{*}{4} & $\begin{array}{l}\text { 20-percent decrease in } \\
\text { recharge }\end{array}$ & $\begin{array}{l}\text { Davenport Branch, tributary to } \\
\text { the Toms River }\end{array}$ & $\begin{array}{l}\text { Decrease base flow } 4.7 \mathrm{ft}^{3} / \mathrm{s} \\
\text { ( } 33 \text { percent) }\end{array}$ \\
\hline & & $\begin{array}{l}\text { Toms River near Toms River, } \\
\text { N.J. }\end{array}$ & $\begin{array}{l}\text { Decrease base flow } 38.2 \mathrm{ft}^{3} / \mathrm{s} \\
\text { ( } 24 \text { percent) }\end{array}$ \\
\hline \multirow[t]{3}{*}{5} & $\begin{array}{l}\text { 20-percent additional decrease } \\
\text { in recharge in urban areas }\end{array}$ & $\begin{array}{l}\text { Toms River near Toms River, } \\
\text { N.J. }\end{array}$ & $\begin{array}{l}\text { Decrease base flow } 1.6 \mathrm{ft}^{3} / \mathrm{s} \\
\text { (1 percent) }\end{array}$ \\
\hline & & North Branch Metedeconk & $\begin{array}{l}\text { Decrease base flow } 2.1 \mathrm{ft}^{3} / \mathrm{s} \\
\text { (5 percent) }\end{array}$ \\
\hline & & $\begin{array}{l}\text { River } \\
\text { South Branch Metedeconk } \\
\text { River }\end{array}$ & $\begin{array}{l}\text { Decrease base flow } 1.3 \mathrm{ft}^{3} / \mathrm{s} \\
\text { (4 percent) }\end{array}$ \\
\hline \multirow[t]{3}{*}{6} & $\begin{array}{l}\text { 25-percent increase in } \\
\text { recharge in urban areas }\end{array}$ & $\begin{array}{l}\text { Toms River near Toms River, } \\
\text { N.J. }\end{array}$ & $\begin{array}{l}\text { Increase base flow } 1.7 \mathrm{ft}^{3} / \mathrm{s} \\
\text { (1 percent) }\end{array}$ \\
\hline & & $\begin{array}{l}\text { North Branch Metedeconk } \\
\text { River }\end{array}$ & $\begin{array}{l}\text { Increase base flow } 2.2 \mathrm{ft}^{3} / \mathrm{s} \\
\text { ( } 5 \text { percent) }\end{array}$ \\
\hline & & $\begin{array}{l}\text { South Branch Metedeconk } \\
\text { River }\end{array}$ & $\begin{array}{l}\text { Increase base flow } 1.3 \mathrm{ft}^{3} / \mathrm{s} \\
\text { (4 percent) }\end{array}$ \\
\hline \multirow[t]{3}{*}{7} & $\begin{array}{l}100 \text {-percent increase in rate of } \\
\text { ground-water evapotranspira- } \\
\text { tion in wetland areas }\end{array}$ & $\begin{array}{l}\text { Ridgeway Branch, tributary to } \\
\text { the Toms River }\end{array}$ & $\begin{array}{l}\text { Decrease base flow } 8.3 \mathrm{ft}^{3} / \mathrm{s} \\
\text { (24 percent) }\end{array}$ \\
\hline & & Toms River & $\begin{array}{l}\text { Decrease base flow } 15.4 \mathrm{ft}^{3} / \mathrm{s} \\
\text { (9 percent) }\end{array}$ \\
\hline & & $\begin{array}{l}\text { South Branch Metedeconk } \\
\text { River }\end{array}$ & $\begin{array}{l}\text { Decrease base flow } 1 \mathrm{ft}^{3} / \mathrm{s} \\
\text { (3 percent) }\end{array}$ \\
\hline
\end{tabular}


In contrast with other model parameters, simulated water levels and base flows were less sensitive to values of vertical leakance and streambed conductance within plausible ranges.

Lower values of vertical leakance resulted in slightly higher water levels and hydraulic gradients. Base flows were essentially unaffected by changes in leakance. Lower values of streambed conductance resulted in slightly higher water levels, uniformly, with little change in hydraulic gradients; base flows in some tributaries decreased slightly, and base flow increased $1.2 \mathrm{ft}^{3} / \mathrm{s}$ in the Davenport Branch. In downstream reaches base flows were essentially unaffected by changes in streambed-conductance values. Slight increases or decreases in effective stream stages slightly raised or lowered ground-water levels in areas where they are controlled by streams. Base-flow distribution was unaffected by stream stage in most areas, with the exception of the Davenport Branch tributary to the Toms River, where an increase in stream stages lowered base flow slightly.

Results of these sensitivity tests provide a limited indication of the accuracy of the model calibration and the relations among data availability, data interpretation, and model accuracy. They also illustrate the way in which the range in plausible values of model parameters are constrained by the amount of available data. Collection of additional key data would further constrain the calibrated parameter values and improve the accuracy of the model calibration.

\section{Transient Calibration}

An analysis of transient conditions was used to quantify changes that occur in the flow system as a result of seasonal variations in recharge rates and hydrologic stresses. The role of aquifer storage in the flow system was examined and quantified by calibrating the flow model to transient conditions and evaluating simulation results. Other model parameters in addition to storage properties were adjusted during transient-model calibration in order to obtain an acceptable match between simulated and observed transient water levels and base flows. Because some of the model parameters adjusted in the transient calibration affect the steady-state simulations, the transient and steady-state models were calibrated simultaneously.

The objective of the transient calibration and subsequent predictive transient simulations is the accurate estimation of monthly water-level fluctuations and base flows, so that the effects of ground-water withdrawals during seasonally dry conditions can be resolved. The ground-waterflow model was calibrated to transient conditions observed during the 12-month period from June 1992 through May 1993; this process resulted in refined estimates of aquifer-system properties, including aquifer storage. During this period, stream discharge was measured continuously at three streamflow-gaging stations $(01408500,01408120$, and 01408150 -locations shown in fig. 2). Water levels were measured continuously at four observation wells $(29-1059,29-1060$, 25-716, and 29-1056--locations shown in fig. 2). From the measurements made during this period, water-table fluctuations in response to seasonal variations in recharge rates at each well location were determined. Hydrograph-separation techniques were used to determine mean monthly base flow at each of the continuous streamflow-gaging stations. Simulated and observed water levels at the four wells were compared. Simulated and observed mean monthly base flows at two of the continuous streamflow-gaging stations were compared. Streamflow measurements of the South Branch Metedeconk River near Lakewood, N.J. (01408150), were not used for model calibration because flow above this station is heavily regulated. The transient-calibration procedure resulted in an acceptable match between simulated and observed water levels and base flows. The following section describes the results of the transient-model calibration and the results of an analysis of the sensitivity of transient-system behavior to changes in selected model parameters. 
Simulation of transient flow requires definition of initial conditions. Because available field data were insufficient to define hydrologic conditions at the beginning of the 12-month calibration period, initial conditions were determined by simulation. A long (41-month) period prior to the calibration period was simulated in order to account for the effects of gradually increasing pumping rates and thus generate appropriate initial conditions. Initial conditions for this precalibration period were defined with reasonable accuracy by heads simulated with the calibrated steady-state model.

The 53-month simulation period (41-month precalibration period plus 12-month calibration period) was discretized into 53 stress periods corresponding to each respective month. Each monthly stress period was represented by 10 time steps, with time-step lengths increasing by a factor of 1.5 through each stress period. Tests on the time-step length demonstrated that this timestepping procedure was adequate to describe the early-time response for each successive stress period. Depending on the length of the particular month, initial time-step lengths ranged from 0.25 to 0.29 days, and final time-step lengths ranged from 9.5 to 10.5 days.

Ground-water withdrawals, ground-water ET, and recharge were defined for each month and are shown in figure 17. Ground-water withdrawals from each well for each month were compiled from the U.S. Geological Survey Site-Specific Water Use Data System (SSWUDS) data base and from data provided by the NJDEP, Bureau of Water Allocation. Withdrawals from 58 to 85 wells were simulated during a given stress period. The largest withdrawals are generally within $10 \mathrm{mi}$ of the coast, near high-density population centers. The rate of ground-water ET over the model area exceeds withdrawals during summer months and is negligible during DecemberFebruary.

Leakage to and from the Piney Point aquifer was represented in transient simulations by using the same boundary heads and boundary conductances that were used in the steady-state simulation of average 1980-89 conditions. Leakage to and from the Piney Point aquifer within the study area is minor and affects only the ground-water budgets of small subbasins.

\section{Recharge}

The hydrologic stress that has the greatest effect on monthly variations in water levels in the Kirkwood-Cohansey aquifer system and base flow of streams in the study area is recharge. The accuracy with which historical water levels and base flows can be reproduced by simulation is highly dependent on the accuracy with which recharge to the aquifer system can be defined. This section describes various factors that affect the spatial distribution and temporal variability of recharge. Also discussed are alternative methods that were explored to determine recharge.

Recharge is usually low or zero during summer, when precipitation is low and potential ET is high. Even large summer storms, such as the storm on July 31,1992 , that are intense but short in duration usually do not contribute substantially to recharging the aquifer (fig. 18). No rain fell during the week before this storm. Because water levels fluctuated little after this storm, it is assumed that the precipitation that fell first satisfied the soil moisture deficit and ET, leaving little for recharge. Occasionally, periods of intense or extended rainfall during summer months can result in significant recharge. During winter and early spring, when the rate of ET is low and soil moisture is above field capacity [the quantity of water that can be permanently retained in the soil in opposition to the downward pull of gravity (Horton, 1935, p. 3)], recharge can be much higher than the average annual rate. 


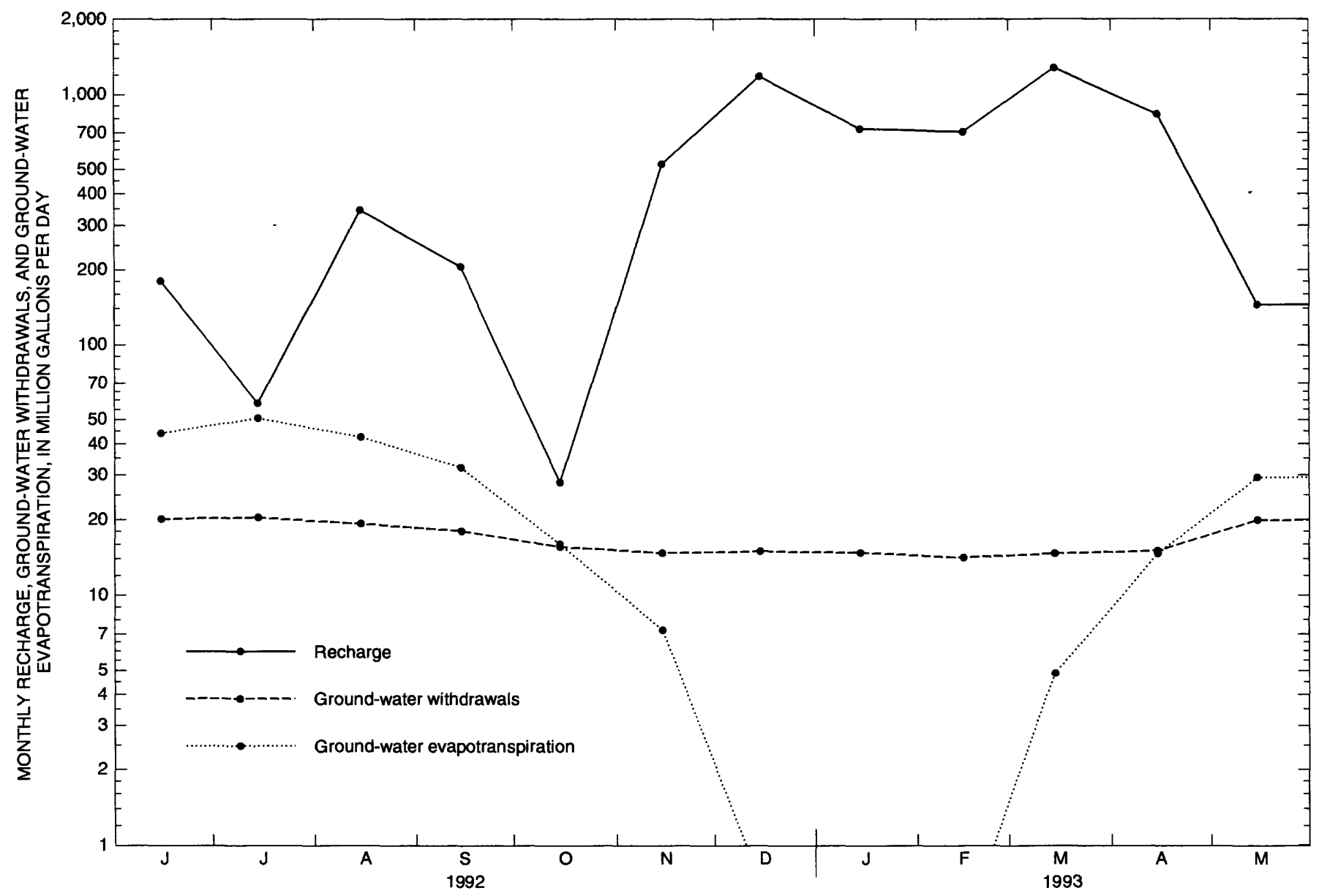

Figure 17. Recharge, ground-water withdrawals, and ground-water evapotranspiration as represented in simulation of transient conditions, June 1992-May 1993, Toms River, Metedeconk River, and Kettle Creek Basins, New Jersey. 
The spatial distribution of precipitation can be highly irregular, as illustrated by patterns of precipitation at three weather stations in and near the study area and by patterns of water-level fluctuations in the four observations wells shown in figure 18. During August 7-19, 1992, a series of major storms passed through southern New Jersey, resulting in total precipitation of 6.3, 2.3, and 2.3 inches at the Toms River, Pemberton, and Hightstown weather stations, respectively (locations shown in fig. 2). The water level in the D and S observation well (29-1056) near the Toms River rose more than $3 \mathrm{ft}$, whereas the level in the Herbert Sand observation well (25-716), in the northern part of the study area, continued to decline. Water levels in the other two observation wells to the west, the Ft. Dix observation well (29-1059) and the Lakehurst observation well (29-1060), rose less than $0.7 \mathrm{ft}$. Although factors other than recharge affect water-level fluctuations, recharge from this August 1992 storm was clearly greater in the southeastern part of the study area than in the northern and western parts.

The time between infiltration and recharge also varies spatially as a function of conditions in the unsaturated zone. Where the water table is near the land surface, recharge occurs shortly after infiltration. Where the water table is tens of feet below land surface, recharge lags behind infiltration by days or even weeks, as shown in figure 18. The presence of low-permeability layers in the unsaturated zone also delays recharge to the water table. Following major storms in June and August 1992, the water level in the Lakehurst observation well (29-1060-average depth to water $26.8 \mathrm{ft}$ ) began to rise promptly, whereas the water level in the Ft. Dix observation well (291059--average depth to water $53 \mathrm{ft}$ ) did not begin to rise for more than 7 days. Recharge to the water table was delayed as water passed through the unsaturated zone. Alley (1984) discusses the relation between depth to water and the time between minimum streamflow and minimum water levels in four other wells tapping the Kirkwood-Cohansey aquifer system. Alley concludes that as depth to water increases, the time between minimum streamflow and minimum water level increases. This time lag can be attributed in part to the time between infiltration and recharge to the water table. The effect of this time lag on recharge was addressed in simulations in a spatially uniform manner; the spatial variability of the time lag was beyond the scope of the study.

In order to simulate monthly variations in base flow and water levels, monthly recharge values must be estimated. Uncertainty in the spatial distribution of recharge and in the timing of recharge following storms limits the accuracy with which monthly water levels and base flows can be simulated. However, several methods of estimating recharge over smaller time increments were considered, and one method was selected as appropriate for defining recharge stresses in transient simulations.

Considerable research has been directed toward the determination of recharge by direct measurement and by indirect methods. Direct measurements of recharge by using lysimeter or tensiometer techniques, as described by Bouwer (1978, p. 266-267), are highly site-specific and, consequently, these techniques would be impractical for the determination of recharge over the entire study area. Therefore, recharge must be estimated by using indirect methods. Three alternative indirect methods were considered and are presented below.

The physical basis for a method of estimating recharge from the analysis of streamflow recession is described by Rorabaugh (1960). This method, known as the "recession-curve displacement method," is expanded upon and automated by Rutledge $(1992,1993)$ and Rutledge and Daniel (1994). As described by Rutledge (1993), "The recession-curve displacement method is based on the upward shift in the streamflow-recession curve that occurs as a result of a recharge event." Computer programs by Rutledge (1993) were used to develop one set of monthly recharge 


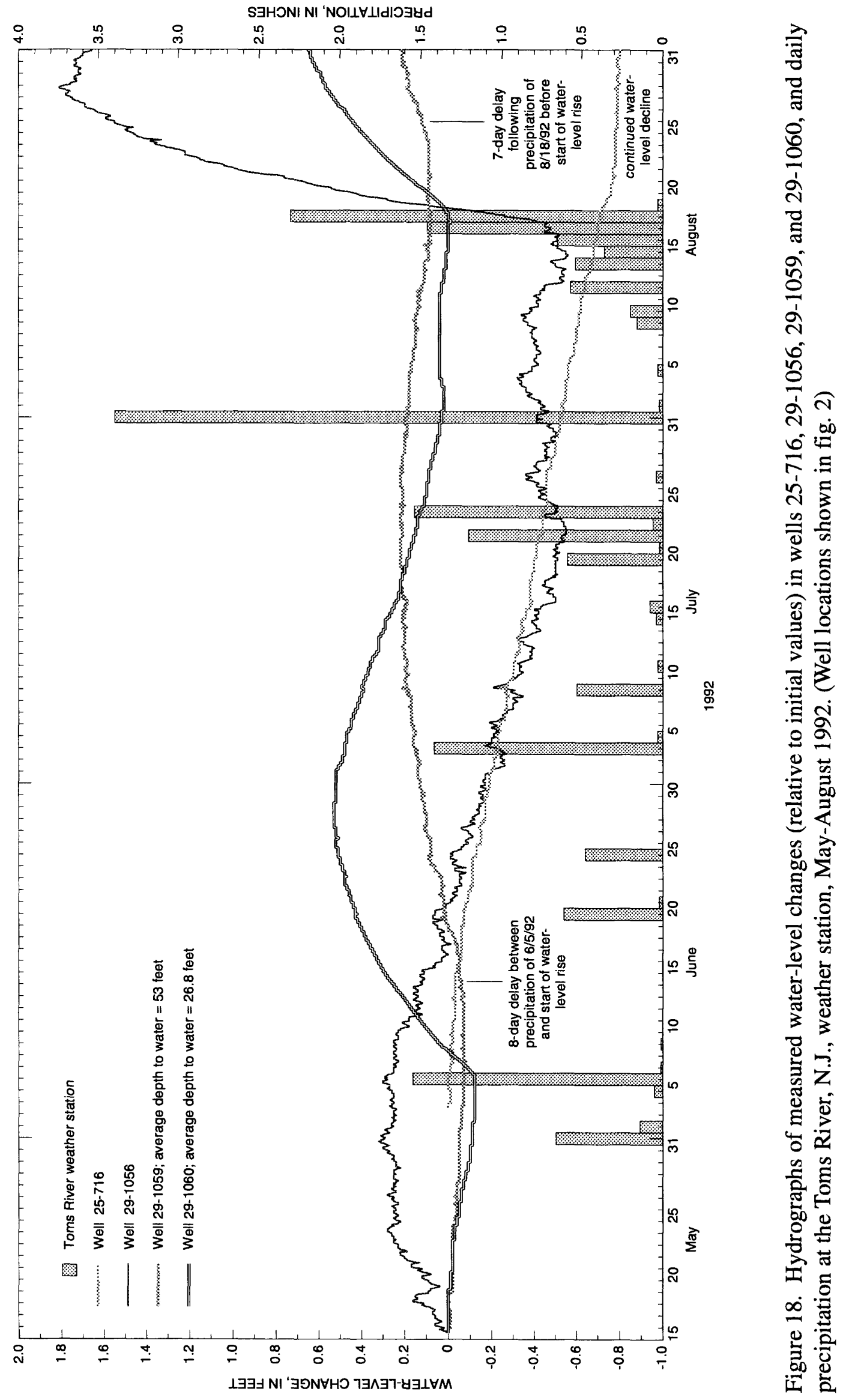


estimates for the study area for January 1989 through May 1993. Monthly recharge estimates for the calibration period (June 1992-May 1993) are shown in figure 19a, along with results of the other methods discussed below. Figure 19a also shows the average total monthly precipitation at the Toms River, Pemberton, and Hightstown, N.J., weather stations. Water levels in the Lakehurst observation well (29-1060) and base flow at the Toms River near Toms River, N.J., streamflowgaging station (01408500) are shown in figure 19b. The water-level and base-flow hydrographs illustrate the actual behavior of the flow system during the time period shown and therefore can be used to evaluate the alternative recharge-estimation methods.

Another common approach to recharge estimation is the land-surface water-budget approach. Simply stated, the land-surface water budget is an accounting of the fate of water that reaches the land surface as precipitation. In this study, the land-surface water-budget equation takes the following form:

$$
P=Q_{d r}+\mathrm{ET}+\mathrm{R}+\Delta \mathrm{SM},
$$

where

$$
\begin{aligned}
& \mathrm{P} \quad=\text { precipitation, in inches; } \\
& \mathrm{Q}_{\mathrm{d}}=\text { direct runoff, in inches (determined through hydrograph-separation techniques); } \\
& \mathrm{ET}=\text { evapotranspiration, in inches (determined by the Thornthwaite method); } \\
& \mathrm{R} \quad \text { = recharge, in inches; and } \\
& \Delta \mathrm{SM}=\text { change in soil-moisture storage, in inches. }
\end{aligned}
$$

Rearranged to solve for recharge, the equation becomes

$$
\mathbf{R}=\mathbf{P}-\mathbf{Q}_{\mathrm{dr}}-\mathrm{ET}-\Delta \mathrm{SM} \text {. }
$$

If, prior to the period of interest, soil moisture is less than the maximum soil-moisture capacity, then a soil-moisture deficit (SMD) exists. Recharge can occur only after the SMD is satisfied.

The period over which water-budget components are estimated can greatly affect the value of calculated recharge. For example, ET for a typical summer month exceeds the sum of precipitation plus the SMD for the previous month. Therefore, if each budget component is estimated on a monthly basis, then recharge tends to be nearly zero for summer months. Recharge calculated from water-budget terms estimated on a monthly basis for June 1992-May 1993 is shown in figure 19a. A maximum SMD of 1.5 inches was assumed.

In reality, however, recharge does occur during summer, major summer storms result in significant infiltration that exceeds the sum of ET and the SMD over short (less than 1-month) periods. This results in recharge, as illustrated by distinct periods of rising ground-water levels during June and August 1992 (fig. 19b). 

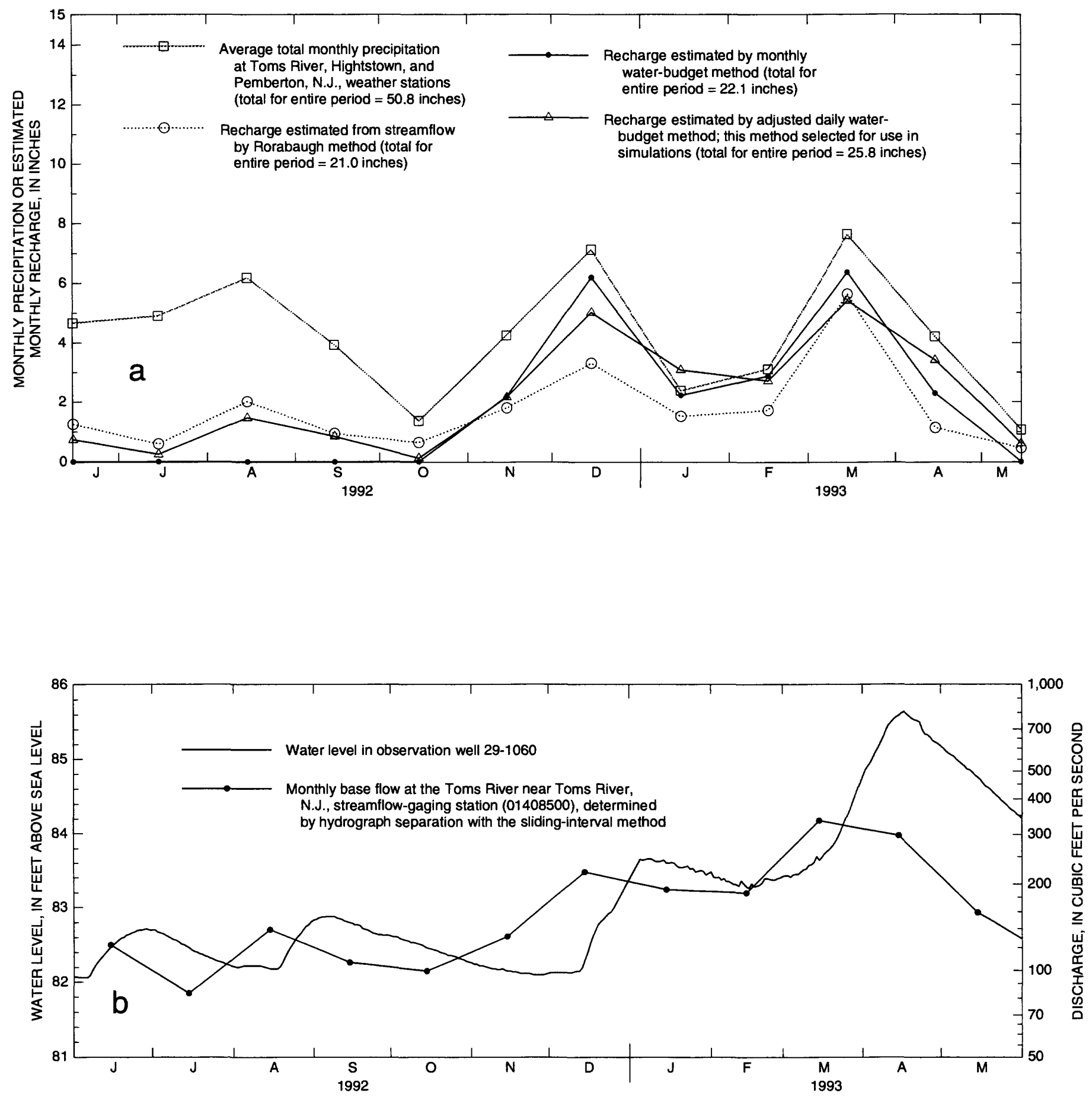

Figure 19. (a) Average total monthly precipitation at Toms River, Hightstown, and Pemberton, N.J., weather stations, and monthly recharge estimated from streamflow data by Rorabaugh (1964) method, by monthly water-budget method, and by adjusted daily water-budget method, June 1992-May 1993; and (b) hydrographs of water levels in well 29-1060 and monthly base flow of Toms River near Toms River, N.J., streamflow-gaging station (01408500), June 1992-May 1993. 
In order to determine recharge more accurately, a modified water-budget approach was applied on a daily basis with more realistic results, and this approach was selected for use in the transient calibration. Daily estimates of water surplus (P - ET - SMD) were calculated and summed over a given month. Daily precipitation was calculated as the average of daily precipitation measured at the Toms River, Hightstown, and Pemberton, N.J., weather stations. Daily ET was interpolated from monthly estimates of potential ET determined by Watt and others (1994) by using the Thornthwaite method. The calculated value of water surplus includes both deep infiltration and direct runoff for a given month. Estimated direct runoff for the month (as determined by hydrograph-separation techniques) was then subtracted, netting an estimate of deep infiltration, which eventually becomes recharge. In order to account for the delaying effect of the unsaturated zone, 25 percent of the amount of deep infiltration for a given month was assumed to recharge the saturated zone during the following month. The procedure is summarized by the equation:

$$
\begin{array}{r}
\left.R_{m}=0.75\left[\sum_{n=1}^{d_{(m)}}\left(P_{(m, n)}-E T_{(m, n)}-S M D_{(m, n-1)}\right)\right]-Q_{d r(m)}\right]+ \\
0.25\left[\left[\sum_{n=1}^{d_{(m-1)}}\left(P_{(m-1, n)}-E T_{(m-1, n)}-S M D_{(m-1, n-1)}\right)\right]-Q_{d r(m-1)}\right],
\end{array}
$$

where

$$
\begin{array}{ll}
\mathrm{d}_{(\mathrm{m})} & =\text { number of days in month } \mathrm{m} ; \\
\mathbf{R}_{(\mathrm{m})} & =\text { recharge for month } \mathrm{m}, \text { in inches; } \\
\mathbf{P}_{(\mathrm{m}, \mathrm{n})} & =\text { precipitation on day } \mathrm{n} \text { in month } \mathrm{m}, \text { in inches; } \\
\mathbf{E T}_{(\mathrm{m}, \mathrm{n})} & =\text { evapotranspiration on day } \mathrm{n} \text { in month } \mathrm{m}, \text { in inches; } \\
\mathrm{SMD}_{(\mathrm{m}, \mathrm{n}-1)} & =\text { soil-moisture deficit from the day preceding day } \mathrm{n} \text { in month } \mathrm{m}, \text { in inches; and } \\
\mathbf{Q}_{\mathrm{dr}(\mathrm{m})} & =\text { direct runoff for month } \mathrm{m}, \text { in inches. }
\end{array}
$$

The resulting monthly recharge estimates are shown in figure 19a. This method of estimating recharge resulted in the most realistic values, so it was selected for use in generating monthly recharge time series for purposes of transient simulation history-matching.

\section{Water Levels}

Simulated and observed water-level changes in the four water-table observation wells are shown in figure 20. In response to recharge during November 1992-March 1993, observed water levels rose several feet. The difference between the minimum water level during NovemberDecember 1992 and the maximum water level during April-May 1993 was used to characterize the seasonal water-level fluctuation. For example, the observed water-level change during this time in the $D$ and $S$ observation well (29-1056) was $4.92 \mathrm{ft}$ (table 8). A statistical measure of the closeness of the match between simulated and observed water-level fluctuations was calculated as the difference between simulated and observed water-level changes during this period. The simulated water-level change in the D and S observation well (29-1056) was $5.18 \mathrm{ft}$; therefore, the difference between simulated and observed water-level changes was $0.26 \mathrm{ft}$. The mean difference between simulated and observed water-level fluctuations was $0.71 \mathrm{ft}$ (table 8). The model overestimated water-level changes in three of the wells and underestimated the change in the fourth well. 

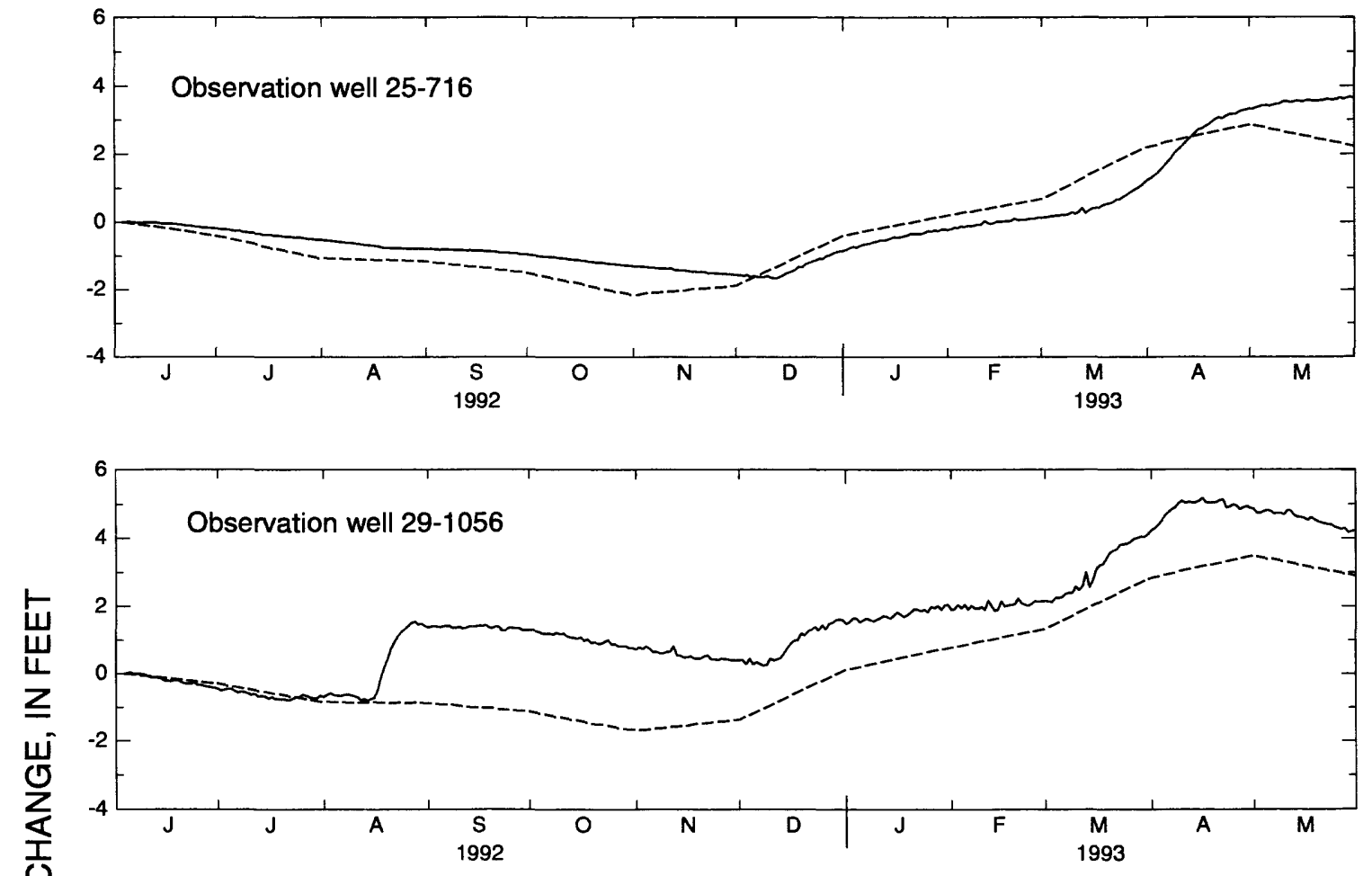

$\frac{1}{4}$
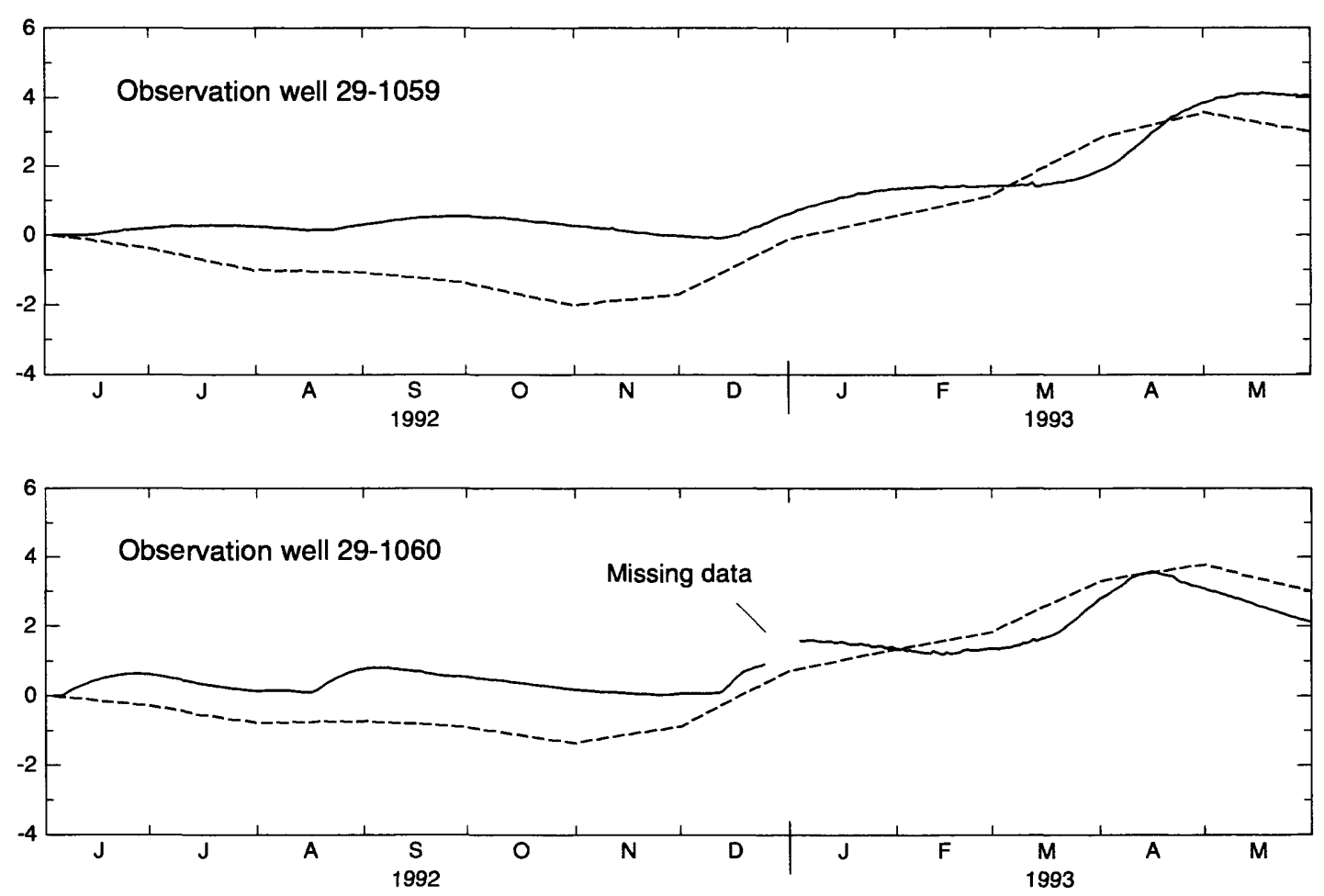

EXPLANATION

Observed -..- Simulated

Figure 20. Observed and simulated water-level changes in four observation wells, June 1992-May 1993, Toms River, Metedeconk River, and Kettle Creek Basins, New Jersey. 
Table 8. Simulated and observed water-level fluctuations in four observation wells, Toms River, Metedeconk River, and Kettle Creek Basins, New Jersey [--, not applicable]

\begin{tabular}{|c|c|c|c|c|}
\hline $\begin{array}{c}\text { U.S. } \\
\text { Geological } \\
\text { Survey } \\
\text { well number }\end{array}$ & $\begin{array}{c}\text { Model cell } \\
\text { coordinates } \\
\text { (layer, row, } \\
\text { column) }\end{array}$ & $\begin{array}{c}\text { Simulated } \\
\text { water-level } \\
\text { fluctuation, } \\
\text { November } \\
\text { 1992-March } \\
\text { 1993 } \\
\text { (feet) }\end{array}$ & $\begin{array}{c}\text { Observed } \\
\text { water-level } \\
\text { fluctuation, } \\
\text { November } \\
\text { 1992-Mąrch } \\
\text { 1993 } \\
\text { (feet) }\end{array}$ & $\begin{array}{c}\text { Difference } \\
\text { between } \\
\text { simulated } \\
\text { and } \\
\text { observed } \\
\text { fluctuation } \\
\text { (feet) }\end{array}$ \\
\hline $29-1056$ & $(1,52,58)$ & 5.18 & 4.92 & 0.26 \\
\hline $29-1059$ & $(1,39,16)$ & 5.57 & 4.24 & 1.33 \\
\hline $29-1060$ & $(1,33,28)$ & 5.14 & 3.54 & 1.60 \\
\hline $25-716$ & $(1,6,41)$ & 5.02 & 5.36 & -.34 \\
\hline Mean & - & - & - & .71 \\
\hline
\end{tabular}

1 Water-level fluctuation is the difference between the minimum water level during November-December 1992 and the maximum water level during AprilMay 1993.

\section{Base Flow}

Simulated mean monthly base flows and base flows determined by hydrograph separation for the Toms River near Toms River, N.J. (01408500), and North Branch Metedeconk River near Lakewood, N.J. (01408120) streamflow-gaging stations are shown in figure 21. Statistics summarizing the match between simulated and observed base flows are listed in table 9 . The mean difference between simulated and determined mean monthly base flow during the calibration period is $4.6 \mathrm{ft}^{3} / \mathrm{s}$ for the Toms River (01408500) and $1.0 \mathrm{ft}^{3} / \mathrm{s}$ for the North Branch Metedeconk River $(01408120)$. These residual values are small in comparison with average base flows, and indicate that any bias in simulated mean monthly base flow is small. The mean absolute difference between simulated and determined base flow for both rivers is less than 16 percent of the respective observed mean base flow, which is considered acceptable. The simulated range in mean monthly base flow for the calibration period was close to the observed base-flow range for both rivers. The close agreement between simulated and determined mean monthly base flows indicates that the transient model represents transient ground-water flow to streams reasonably well. 

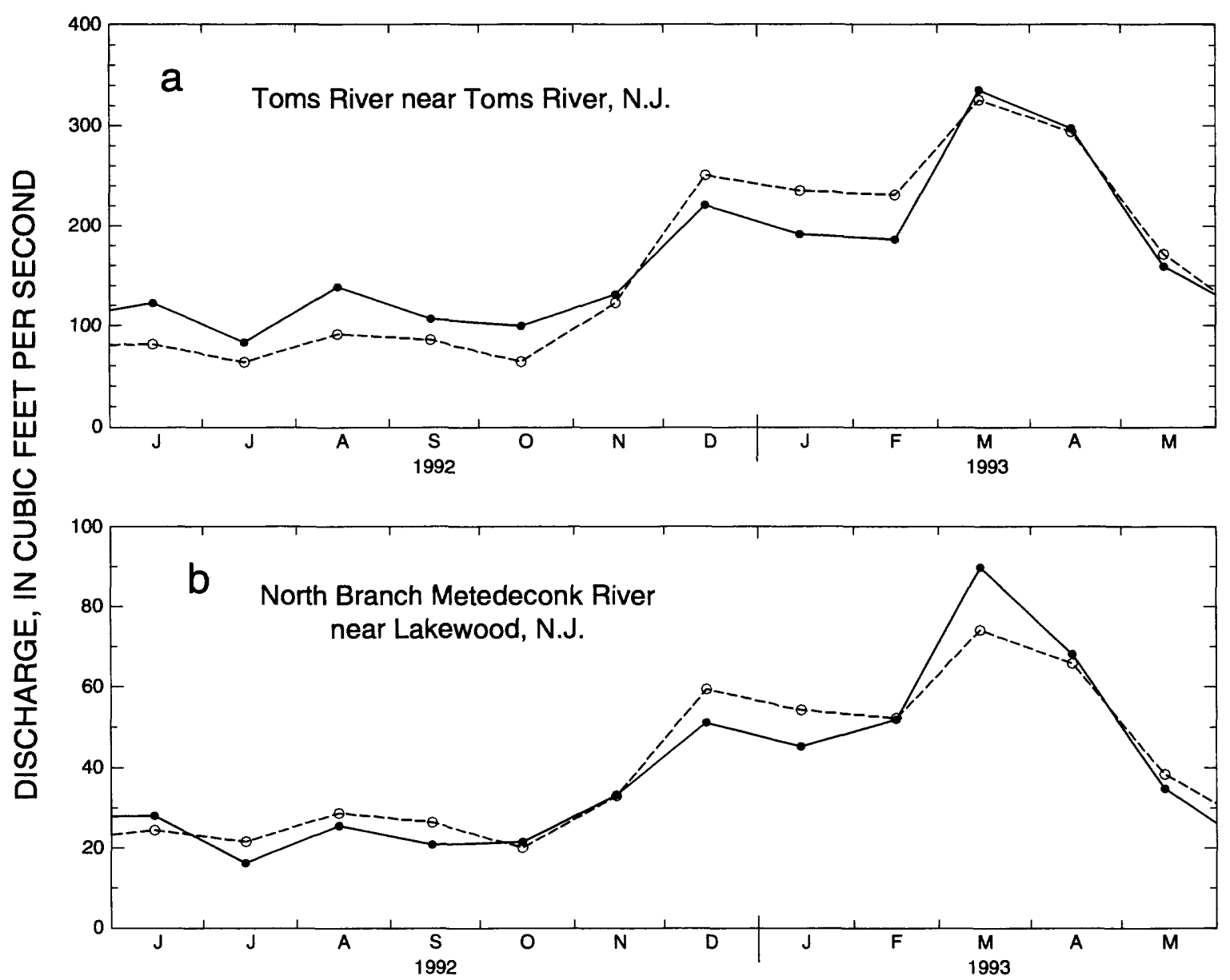

\section{EXPLANATION}

Base flow determined by hydrograph separation

Simulated base flow

Figure 21. Observed and simulated average monthly base flow of the (a) Toms River near Toms River, N.J. (01408500), and (b) North Branch Metedeconk River near Lakewood, N.J. (01408120). 
Table 9. Simulated base flows and base flows determined by hydrograph separation, June 1992-May 1993, Toms River, Metedeconk River, and Kettle Creek Basins, New Jersey

\begin{tabular}{|c|c|c|c|c|c|}
\hline $\begin{array}{l}\text { Streamflow- } \\
\text { gaging- } \\
\text { station name }\end{array}$ & $\begin{array}{l}\text { Streamfiow- } \\
\text { gaging- } \\
\text { station } \\
\text { number } \\
\text { (location } \\
\text { shown in } \\
\text { fig. 2) }\end{array}$ & $\begin{array}{c}\text { Simulated } \\
\text { mean base } \\
\text { flow } \\
\text { (cubic feet } \\
\text { per second) }\end{array}$ & $\begin{array}{c}\text { Mean base } \\
\text { flow } \\
\text { determined } \\
\text { by } \\
\text { hydrograph } \\
\text { separation } \\
\text { (cubic feet } \\
\text { per second) }\end{array}$ & $\begin{array}{c}\text { Mean } \\
\text { difference } \\
\text { between } \\
\text { simulated } \\
\text { and } \\
\text { determined } \\
\text { mean } \\
\text { monthly } \\
\text { base flows } \\
\text { (cubic feet } \\
\text { per second) }\end{array}$ & $\begin{array}{c}\text { Mean } \\
\text { absolute } \\
\text { difference } \\
\text { between } \\
\text { simulated } \\
\text { and } \\
\text { determined } \\
\text { mean } \\
\text { monthly } \\
\text { base fiows } \\
\text { (cubic feet } \\
\text { per second) }\end{array}$ \\
\hline $\begin{array}{l}\text { Toms River } \\
\text { near Toms } \\
\text { River, N.J. }\end{array}$ & 01408500 & 168.1 & 172.7 & -4.6 & 26.4 \\
\hline $\begin{array}{l}\text { NorthBranch } \\
\text { Metedeconk } \\
\text { River near } \\
\text { Lakewood, } \\
\text { N.J. }\end{array}$ & 01408120 & 41.5 & 40.5 & 1.0 & 4.9 \\
\hline
\end{tabular}

\section{Sensitivity Analysis}

The results of the transient-model calibration demonstrate that the model reproduces historical water-level and base-flow fluctuations with reasonable accuracy. Alternative models that use different combinations of parameter values could similarly reproduce historical fluctuations reasonably well. The transient-model calibration, like the steady-state-model calibration, is not a unique solution. Consequently, the sensitivity of the calibrated-transient-model response to various model parameters such as aquifer-storage properties, streambed conductance, and recharge also needs to be tested. The results of this evaluation provide a semiquantitative relation between the model parameters tested and fluctuations in water levels and base flows. The results also can be useful in guiding future data-collection efforts for the purpose of improving the model calibration.

In model layer 1, aquifer-storage properties control the water-level response to the addition or release of water to or from storage. Therefore, simulated water-level fluctuations are expected to be sensitive to aquifer-storage properties. Calibrated values of specific yield $\left(\mathrm{S}_{\mathbf{y}}\right)$ (fig. 10) were increased or decreased by a factor of 1.5 to test model sensitivity to this parameter. Lower values of $S_{y}$ resulted in a larger range in water levels, and higher values resulted in a smaller range, or a flatter hydrograph. When the lower values were used, the simulated water table at the location of well 25-716, for example, fluctuated over a range that is $3 \mathrm{ft}$ larger than that shown for the calibration run in figure 20 . Base-flow fluctuations are similarly affected by specific yield; when the lower values of $S_{y}$ were used, the simulated base flow of the Toms River fluctuated over a range that is $29 \mathrm{ft}^{3} / \mathrm{s}$ larger than that shown for the calibration run in figure 21 . 
The effects of varying streambed conductance on base flow are inverse to the effects of varying aquifer-storage characteristics; if other aquifer-system characteristics remain the same, then lower values of streambed conductance result in less base-flow fluctuation, and higher values of streambed conductance result in more base-flow fluctuation. If streambed conductance is high, hydraulic head in the aquifer beneath streams is near stream stage. Therefore, as ground-water levels in interstream areas rise and fall through time, the aquifer head beneath the stream remains near stream stage. The hydraulic gradient toward streams, therefore, changes significantly through time, resulting in large fluctuations in base flow. If streambed conductance is low, however, the hydraulic head beneath streams rises and falls with the water table and, consequently, both the hydraulic gradient and base flow fluctuate less.

Seasonal variations in recharge rate greatly affect the magnitude of water-level and baseflow fluctuations. As discussed previously, different methods of estimating monthly rates of recharge yield different results (fig. 19). Transient models in which different combinations of aquifer-storage characteristics, streambed conductance, and monthly recharge are used could respond similarly. Among these three model parameters, the model error associated with uncertainty in estimates of monthly recharge is greatest. Improved estimates of monthly recharge would be most useful in improving the transient-model calibration.

\section{GROUND-WATER FLOW UNDER PREDEVELOPMENT AND RECENT CONDITIONS}

The calibrated steady-state and transient models were used to determine conditions that prevailed prior to development. This analysis highlights the natural features of the system that control ground-water flow. The system under recent conditions also was analyzed, and changes to the flow system that have occurred as a result of human activities were estimated. Changes in flow patterns, water levels, base flow, and water budgets were quantified, and the uncertainty inherent in these estimates was investigated. The analysis of past changes provides a context for predicting likely future changes.

\section{Predevelopment Conditions}

Before the New Jersey Coastal Plain was developed, ground-water flow in the study area was controlled by natural rates of recharge and discharge to surface waters. Patterns of groundwater flow in many areas have remained virtually unchanged; in other areas, however, flow patterns and water budgets have changed in response to human activities. Although available data are insufficient to define the predevelopment flow system as thoroughly as the current system, an investigation of predevelopment conditions is useful for the purpose of estimating the location and magnitude of hydrologic changes that have resulted from recent human activities. Average predevelopment flow conditions were simulated by using the same parameters used in the calibrated steady-state-flow model, with boundaries and stresses adjusted to represent conditions that prevailed prior to development.

Recharge rates were set to rates that are thought to have prevailed prior to urbanization. All withdrawal stresses were removed. Piney Point aquifer boundary heads were determined from the prepumping potentiometric surface interpreted by Zapecza and others (1987, fig. 8). The boundaries representing the Point Pleasant Canal and Manasquan Reservoir in the calibrated model were removed and replaced by boundaries representing predevelopment drainage features. 


\section{Average Ground-Water-Flow Patterns}

The simulation of predevelopment conditions demonstrates patterns of ground-water flow that are typical of shallow, unconsolidated aquifers in the New Jersey Coastal Plain. Most recharge occurs in interstream upland areas, and most ground water flows toward surface-waterdischarge boundaries. Simulated water-table contours and flow directions are shown in figure 22. Flow vectors indicate the magnitude and direction of horizontal ground-water flow. Flow vectors are notably shorter in the Metedeconk River Basin and in the upper part of the Toms River Basin than in other areas for two reasons. The first is that these areas receive less recharge than the rest of the model area, so flow from one model cell to another is less overall; the second is that the lengths of the flow vectors shown are proportional to the horizontal component of total flow, so that projected vectors representing a large flow rate that is mostly vertical appear short. Vectors appearing as mere arrowheads indicate that flow is predominantly vertical.

In the Metedeconk River Basin and the upper part of the Toms River Basin, where horizontal hydraulic conductivity is lower and ground-water gradients are higher than in other parts of the study area, ground water flows along paths that are nearly perpendicular to the general streamchannel orientation. The Metedeconk River generally flows from northwest to southeast; ground water in many parts of this basin flows toward the northeast or southwest. As a result of this flow pattern, subregional ground-water divides separating ground-water subbasins are fairly distinct, and their locations can be determined roughly from the examination of flow vectors. In contrast, ground-water-flow directions in areas where horizontal hydraulic conductivity is higher and hydraulic gradients are lower, such as the lower part of the Toms River Basin, more closely parallel stream-channel orientation. Subregional ground-water divides in these areas are less evident from the examination of flow vectors.

The simulated predevelopment potentiometric surface of model layer 2 is similar to that of model layer 1, except near the coast. In the deep part of the system near the coast, simulated water levels are 2 to $5 \mathrm{ft}$ above sea level, which is consistent with reports of historically flowing coastal wells and other coastal wells in which predevelopment water levels were several feet above sea level (Zapecza and others, 1987, fig. 10, p. 116; Seaber, 1963, p. 113, 160, 163).

Vertical flow directions in the Kirkwood-Cohansey aquifer system under predevelopment conditions generally are downward in interstream areas and upward near surface-water boundaries (fig. 23). Flow is upward near streams, except near headwater streams that are not directly connected to the ground-water system. Streamflow in these channels probably consists of storm runoff and interflow. Several examples of these disconnected stream channels are the headwaters of Davenport Branch and Union Branch in Manchester Township. Flow is generally upward near the embayments.

Predevelopment vertical flow directions across the bottom of the Kirkwood-Cohansey aquifer system (model layer 2) are shown in figure 24. Ground water flows downward into the Vincentown aquifer (shown at the top of the figure) in interstream areas, and upward near streams. Ground water flows downward to the Piney Point aquifer (shown at the bottom of the figure) only in the southwestern part of the study area. Ground water flows upward in other areas where the Piney Point aquifer is present in the study area. 


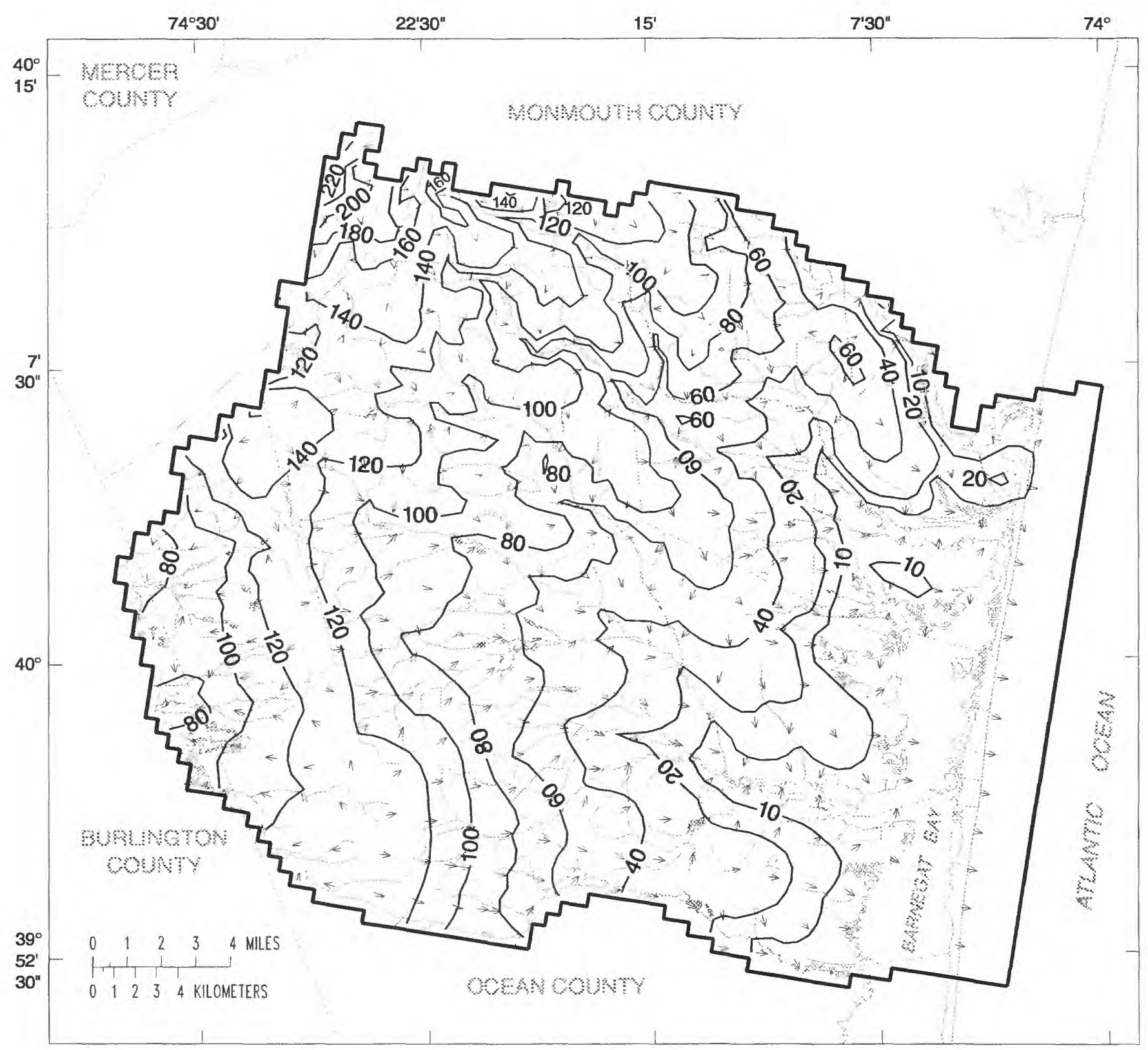

EXPLANATION

- 20- SIMULATED WATER-TABLE CONTOUR--Shows altitude of simulated average, recent (1980-89) water table. Contour interval 10 and 20 feet. Datum is sea level

Model boundary, layer 1

$\rightarrow$ FLOW VECTOR--Indicates direction and magnitude of the horizontal component of flow in a selected model cell. The length of each flow vector is proportional to the logarithm of the horizontal component of flow. Flow corresponding to vector length can be calculated by using the equation:

FLOW (cubic feet per second) $=0.025 \times \log _{10}{ }^{-1}(0.75 \times$ LENGTH (millimeters))

1 millimeter $=0.14$ cubic feet per second; 2 millimeters $=0.79$ cubic feet per second

Figure 22. Simulated water levels and flow directions in model layer 1 under predevelopment conditions, Toms River, Metedeconk River, and Kettle Creek Basins, New Jersey. 


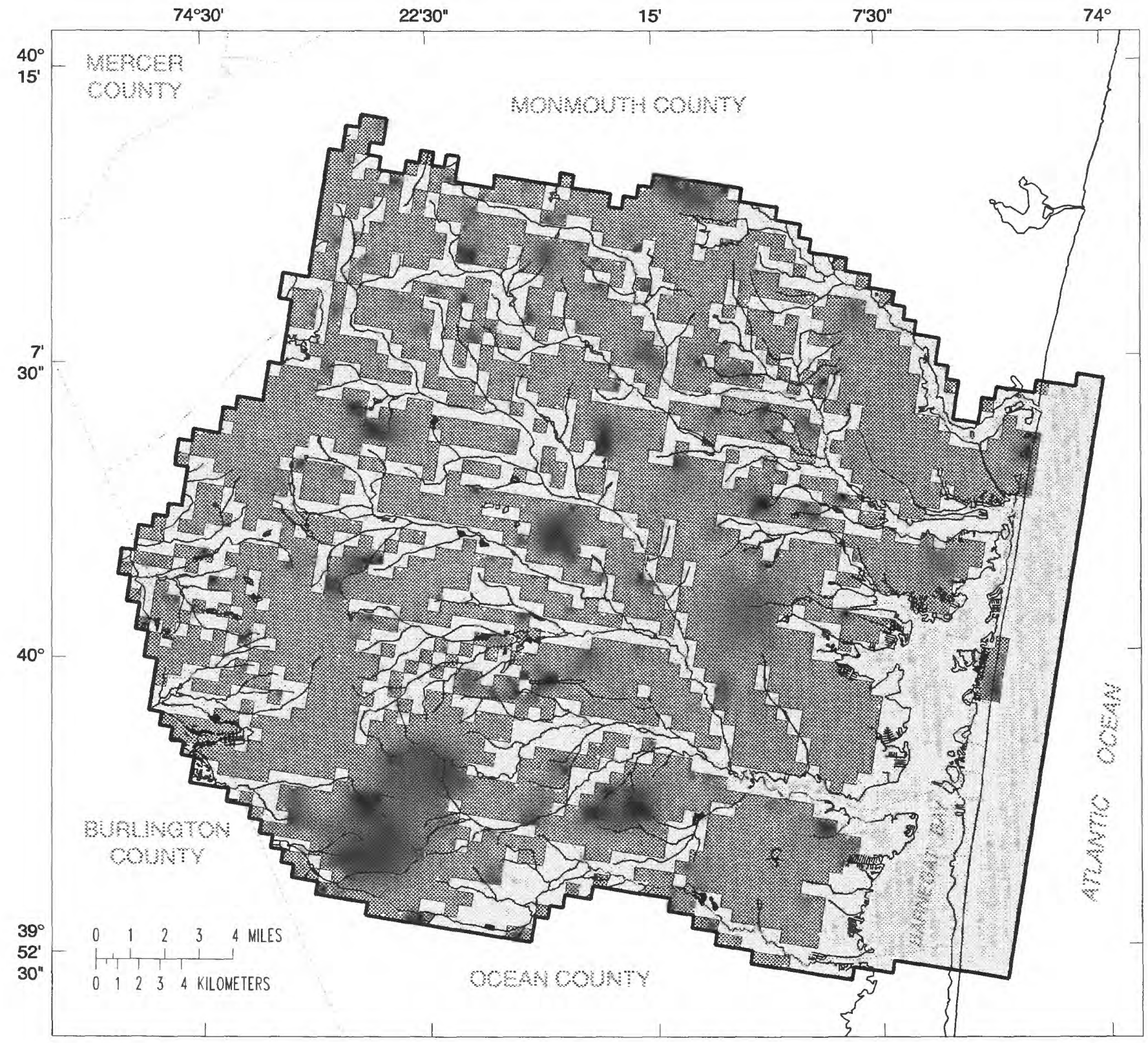

\section{EXPLANATION}

Downward flow

Upward flow

Model boundary, layer 1

Figure 23. Vertical flow directions across bottom of model layer 1 under predevelopment conditions, Toms River, Metedeconk River, and Kettle Creek Basins, New Jersey. 


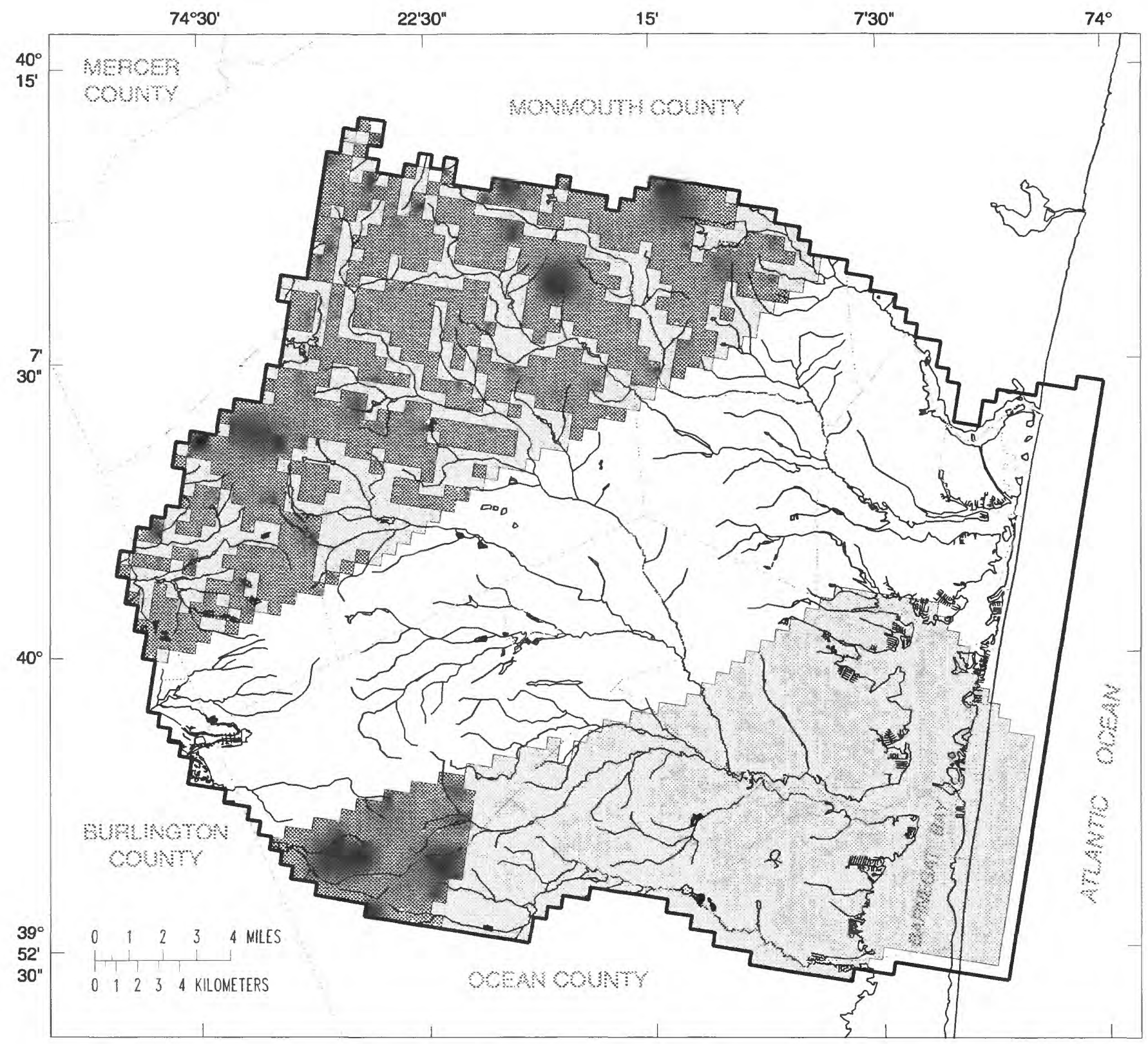

\section{EXPLANATION}

Downward flow

Upward flow

No-flow boundary at bottom of layer 2; no vertical flow present

Model boundary, layer 2

Figure 24. Vertical flow directions across bottom of model layer 2 under predevelopment conditions, Toms River, Metedeconk River, and Kettle Creek Basins, New Jersey. 
The locations of selected ground-water divides and the extents of selected ground-water subbasins were determined from a flow-path analysis of the simulated predevelopment flow field (fig. 25). The results of this analysis can be used to help explain differences in "unit base flow" (base flow per unit drainage area) between streams.

Flow paths were analyzed by using particle-tracking techniques (Pollock, 1989; Pollock, 1994) to delineate the recharge areas that contribute flow to streams. The land-surface area contributing recharge that eventually discharges to a particular stream or tributary is considered a ground-water basin, or subbasin.

Four particles were assigned starting locations equidistant from one another on the top face of each of the uppermost cells that receive recharge. Particles were tracked in the forward direction through the flow field. The final locations were used to identify particles following flow paths that terminate at a particular stream reach.

Many of the minor differences between the locations of ground-water divides and those of surface-water divides (fig. 25) are model artifacts attributable to the scale of horizontal discretization and representation of surface-water boundaries. Finer discretization and representation of unmapped tributaries would have resulted in greater resolution of the locations of ground-water divides, and probably in greater coincidence with mapped surface-water divides in some areas. In other areas, these discrepancies appear to be real differences between ground-water and surfacewater divides. The Wrangel Brook and Union Branch ground-water subbasins occupy sizable parts of the Davenport Branch and Rancocas River drainage areas. The headwater tributaries of the Davenport Branch and some Rancocas River tributaries to the west are high (greater than 120 $\mathrm{ft}$ above sea level) relative to the nearby Wrangel Brook and Union Branch channels (100 ft above sea level), and are not hydraulically connected to the regional ground-water system. Because recharge entering the ground-water system near these headwater tributaries flows to Wrangel Brook and Union Branch, respectively, these streams have higher average unit base flows [base flow per unit drainage area of $\left.1.7\left(\mathrm{ft}^{3} / \mathrm{s}\right) / \mathrm{mi}^{2}\right]$ than Davenport Branch $\left[1.4\left(\mathrm{ft}^{3} / \mathrm{s}\right) / \mathrm{mi}^{2}\right]$ (calculated from data listed in table 6).

Some of the ground-water basins shown in figure 25 appear to contain unshaded "holes," such as the one in the northernmost part of the Toms River Basin and the one in the Davenport Branch Basin. These holes, generally located near ground-water divides, represent areas where ground water flows along relatively deep flow paths to discharge boundaries located outside the ground-water basin in which the hole appears. A more detailed analysis of the flow system would reveal additional recharge areas to deep-flow subsystems.

\section{Seasonal Variations}

Predevelopment flow conditions during a typical seasonal cycle were simulated by using the steady-state-model parameters and boundaries that were used to simulate average predevelopment conditions, and storage coefficients estimated through transient calibration. Analysis of the seasonal response under prepumping conditions provides a means of evaluating seasonal processes that are unrelated to the effects of ground-water withdrawals. The results of prepumping seasonal simulations can then be compared with recent seasonal conditions in order to evaluate the seasonal effects of recent withdrawals. 


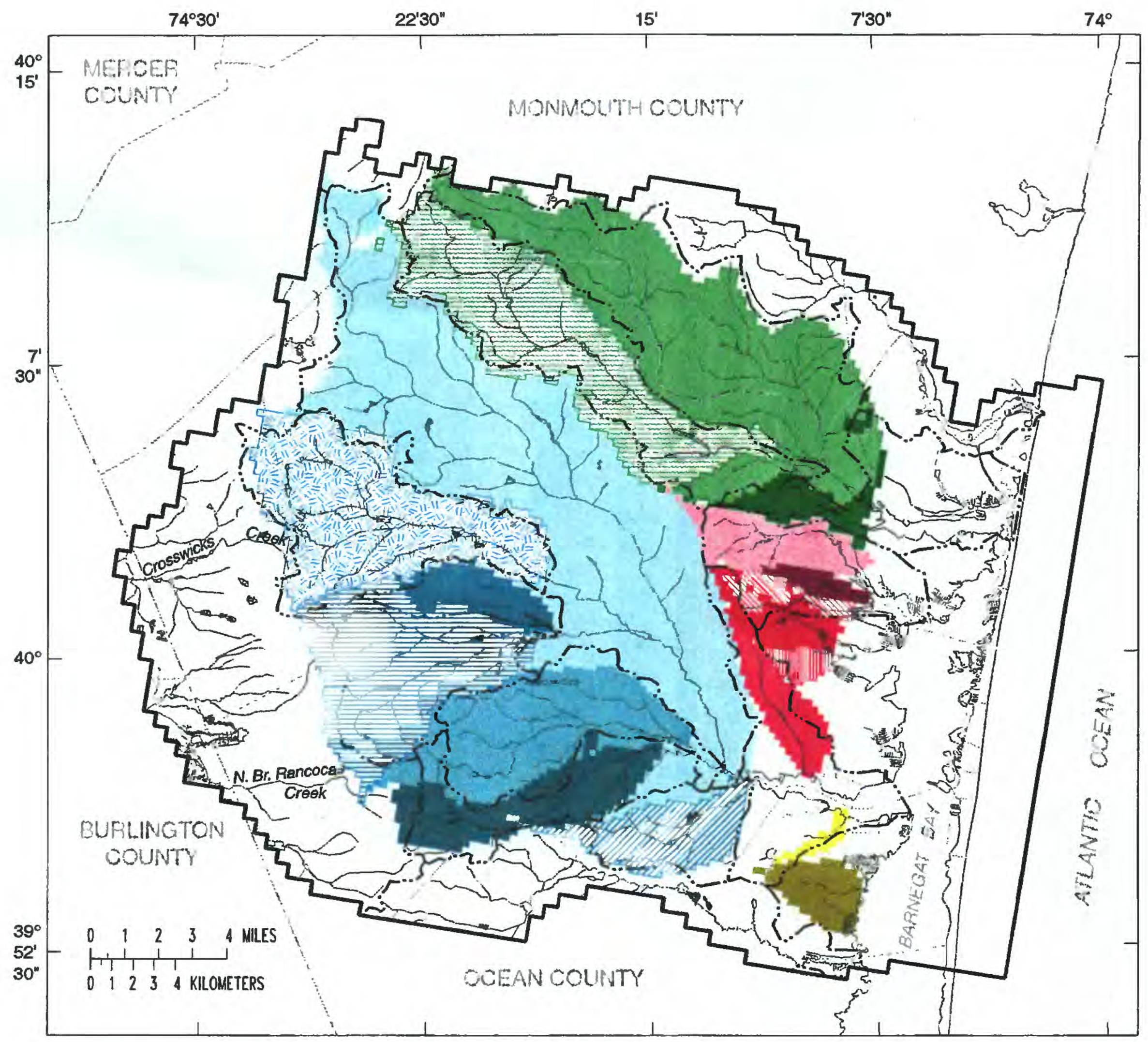

\section{EXPLANATION}

Metedeconk River above head of tide

South Branch Metedeconk River above streamflowgaging station 01408150

Cedar Bridge Branch

Kettle Creek above head of tide

Long Causeway Branch

Polhemus Branch

Unnamed tributary

Unnamed tributary

Long Swamp Branch
WIIJ Jakes Branch

$\square$ Toms River above confluence with Jakes Branch

Wrangel Brook above low-flow statioh 01408600

Davenport Branch above low-flow station 01408630

Union Branch above low-flow station 01408440

Manapaqua Branch above low-flow station 01408460

Ech Ridgeway Branch above low-flow station 01408490

Potter Creek/Clamming Creok

Mill Creok

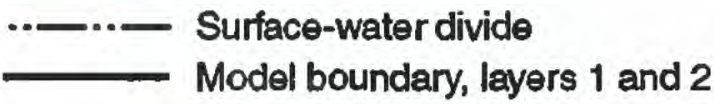

Figure 25. Simulated ground-water basins and surface-water divides under predevelopment conditions, Toms River, Metedeconk River, and Kettle Creek Basins, New Jersey. 
The recharge rate for each month was estimated as the 4-year average recharge for each respective month during 1989-92 (fig. 26a). Annual precipitation during 1989-92 averaged 47.9 inches, which is near normal. During any given 12-month period, seasonal recharge rates can fluctuate more or less than those shown in figure $26 \mathrm{a}$.

Simulated predevelopment base flow of the Toms River through a typical 12-month cycle is shown in figure $26 \mathrm{~b}$. The highest base flow (about $300 \mathrm{ft}^{3} / \mathrm{s}$ ) occurs during early spring, coinciding with the highest rate of recharge. The lowest base flow (about $160 \mathrm{ft}^{3} / \mathrm{s}$ ) occurs during early autumn, following the extended summertime period of low recharge. The same pattern, which is typical of streams in the New Jersey Coastal Plain, was simulated for the other streams in the study area.

Simulated predevelopment water levels at two locations, one near a headwaters stream at model node (layer, row, column) $=(1,26,15)$ and one near a ground-water divide at model node (layer, row, column $)=(1,24,12)$, are shown in figures $26 \mathrm{c}$ and $26 \mathrm{~d}$. The seasonal pattern of rising and falling water levels is generally similar to that of base flow, but is more gradual. For example, base flow declines slightly during February in response to a slightly lower rate of recharge (fig. 26b), while the water levels near the ground-water divide (fig. 26d) continue to rise. Water levels also tend to reach their respective maximum and minimum later in the seasonal cycle than base flows. This delayed response is typical of conditions observed in the field in this and other studies (Anderson and Appel, 1969, p. 16-17). The maximum water level near the headwaters stream, shown in figure 26c, occurs at the end of March, whereas the peak water level near the ground-water divide (fig. 26d) occurs at the end of April. The earlier peak near the stream is a consequence of proximity to the stream discharge boundary; following a seasonal decrease in recharge rate, a discharging stream lowers nearby water levels before more distant water levels.

Two ground-water budgets for the Toms River Basin--one for conditions during early spring (March) when recharge is high and one for conditions during early autumn (October) when recharge is low--are shown in figure 27 . The budgets show that during spring, surplus recharge augments the volume of stored water in the aquifer system, and is subsequently released during drier periods when recharge is low. Seasonal differences in the rate at which water is flowing into or out of storage in the aquifer system are much larger than the differences in ground-water ET, leakage to underlying aquifers, and other budget components.

\section{Recent Conditions}

Watt and others (1994, sheet 5) document the pattern of population growth in the study area from 1930 through 1988 and the increase in water use during 1975-88. Human activities accompanying this growth include ground-water withdrawals, changes in land use and land cover, rerouting of storm runoff, construction of reservoirs and other surface-water impoundments, and construction of new surface-water channels for navigation and drainage. Additionally, changes in water-management strategies have resulted in changes in the location and magnitude of hydrologic stresses. Examples of this type of change are the extension of public water-supply systems to water users who were previously self-supplied and the extension of sewer service into areas previously serviced by on-site sewage-disposal facilities.

The history of these changes is complex; many of the changes have occurred simultaneously over many decades. Consequently, the task of relating human activities to changes in the available historical hydrologic record is no simple matter. The detection of water-level and base- 

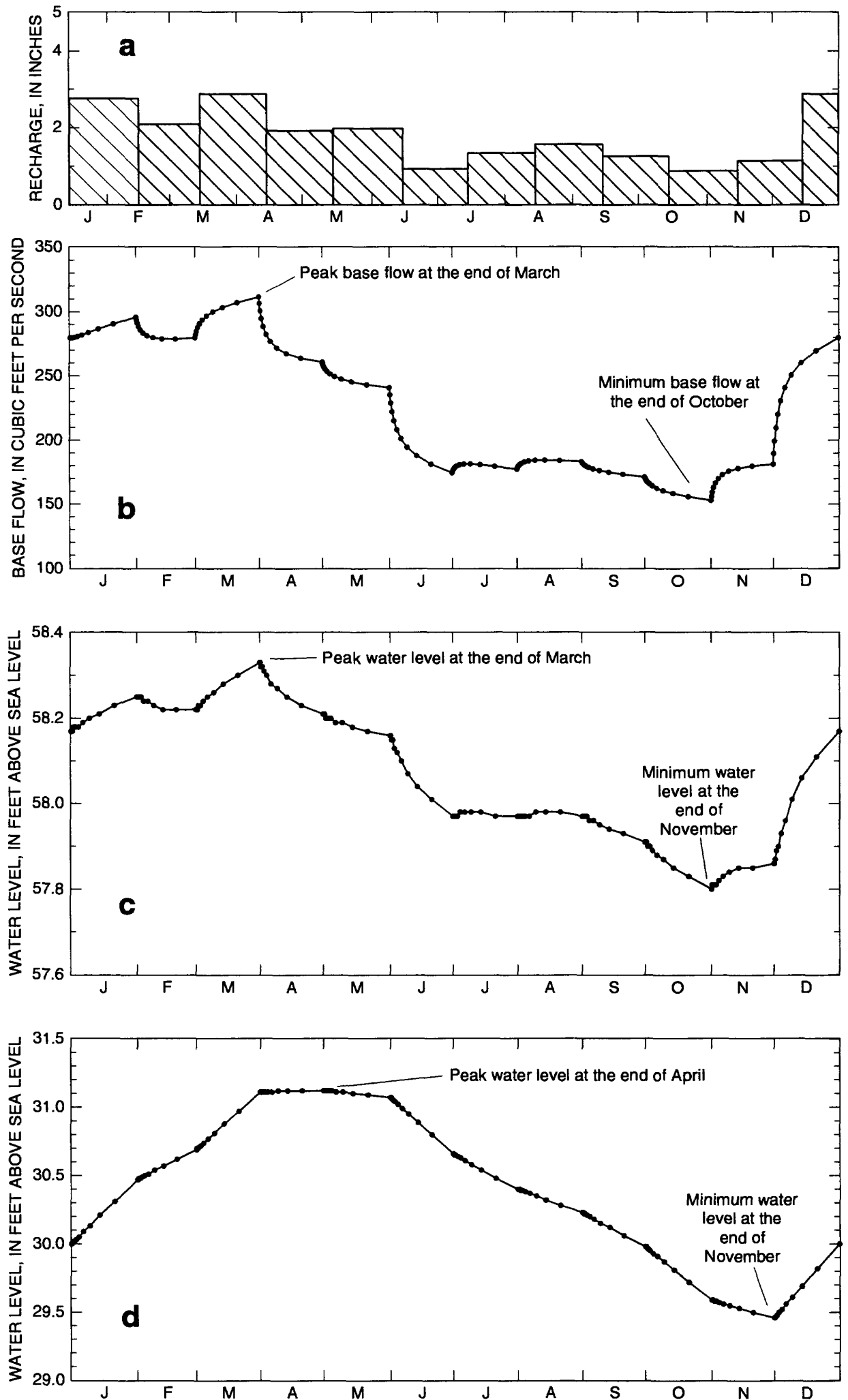

Figure 26. (a) Average monthly recharge; (b) simulated predevelopment base flow of the Toms River during a typical annual cycle; (c) water levels at model node (layer, row, column $)=(1,26,15)$ near the headwaters of Ridgeway Branch tributary to the Toms River; and (d) water levels at model node (layer, row, column) $=(1,24,12)$ near the topographic high between the Toms River and Crosswicks Creek, N.J. (Modelcell locations shown in fig. 2) 


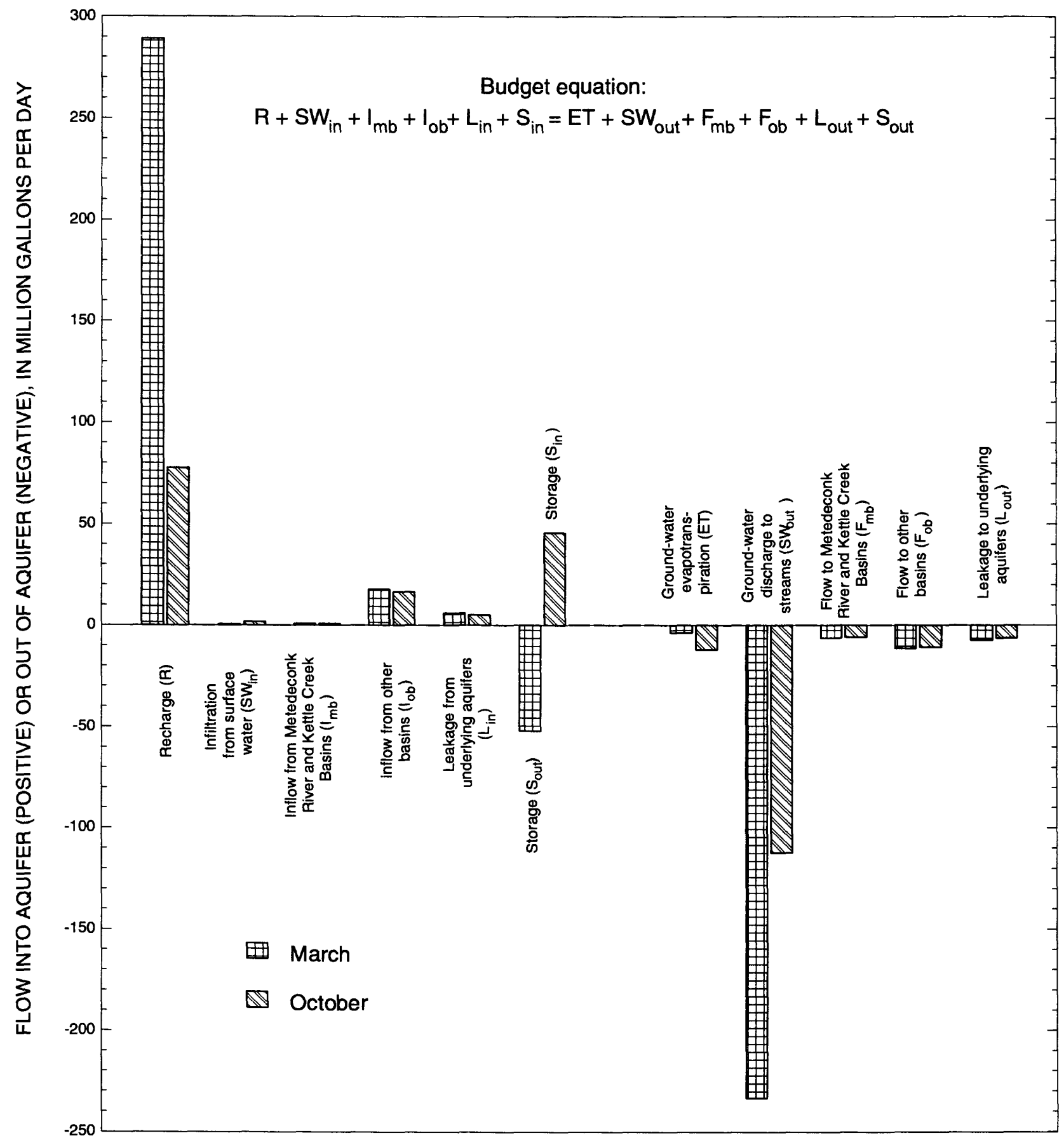

Figure 27. Typical ground-water budgets for the Toms River Basin, N.J., March and October, under predevelopment conditions. 
flow trends in an unconfined aquifer system is further complicated by natural seasonal fluctuations. Meaningful trends may go undetected if natural fluctuations are relatively large. Furthermore, the hydrologic data collected in the study area over the years are sparse and the locations of data-collection stations are not optimal for the detection of trends in water levels and base flows. In light of these difficulties, the historical record was examined by using a variety of techniques in an attempt to characterize the measurable hydrologic changes that have occurred as a result of human activities. The simulation of the recent flow system is an integral part of this analysis.

\section{Historical Trends}

The long period of record (1932-94) for the continuous streamflow-gaging station, Toms River near Toms River, N.J. (01408500), provides the best opportunity to detect trends in base flow in the study area. The other continuous streamflow-gaging stations, North Branch Metedeconk River near Lakewood, N.J. (01408120), and South Branch Metedeconk River near Lakewood, N.J. (01408150), have been operated for only 22 and 2 years, respectively, and provide insufficient data to evaluate trends in base flow. Base flow of the Toms River near Toms River, N.J., as a percentage of total streamflow during 1932-90 is shown in figure 28. Annual base flow was determined by using the hydrograph-separation techniques described earlier. The 3-year moving average of this statistic declined slightly, from about 86 percent in the 1930's to about 84 percent, during 1980-90. This decline could be the result of slightly decreased base flow, slightly increased direct runoff, or both. Nevertheless, the change in mean annual base flow relative to mean annual flow of the Toms River since the early 1930's is small.

Water levels are expected to have declined in the vicinity of major pumping centers. However, few data are available to quantify these effects. Anderson and Appel $(1969$, p. 48, 87) discusses declining water levels in the Kirkwood Formation in Ocean County, and notes that a few wells in the Kirkwood Formation that flowed at one time no longer flowed in 1969. Water levels in the Crammer observation well (29-486), a water-table well in Manchester Township, N.J. (location in fig. 2), recorded continuously from May 1952 through mid-September 1990, present an opportunity to estimate the change in water-table altitude at that location during that time period. Withdrawals from public-supply wells in Manchester Township, N.J., increased from $419 \mathrm{Mgal} / \mathrm{yr}$ in 1975 to $1,019 \mathrm{Mgal} / \mathrm{yr}$ in 1988. Many of these public-supply wells are located within 2 mi of the Crammer observation well, and this additional stress could have resulted in a water-table decline of observable magnitude. Watt and others (1994) discuss the relation between water-level fluctuations in this well and variations in annual precipitation, and conclude that the water level in the well declined about $2 \mathrm{ft}$ during 1974-90.

In order to test the hypothesis that periods of lower-than-normal precipitation caused the water level to decline, the hydrographs of the Crammer observation well (29-486) and a second well were examined. The second well, Lebanon State Forest observation well (5-689), is outside the study area, about $8 \mathrm{mi}$ southwest of the Crammer observation well, in an undeveloped, forested area where water levels are essentially unaffected by human activities (well location in fig. 2). The two wells are in areas expected to receive similar rates of recharge. When concurrent minimum monthly water levels were compared, a clear relation between the water levels was apparent; both water levels fluctuated in the same cyclic manner in response to changing seasonal conditions (fig. 29). An empirical relation determined by trial-and-error was used to predict the early (1955-75) water-level history of the Crammer observation well from the observed early water-level history of the Lebanon State Forest observation well with a high level of accuracy. 


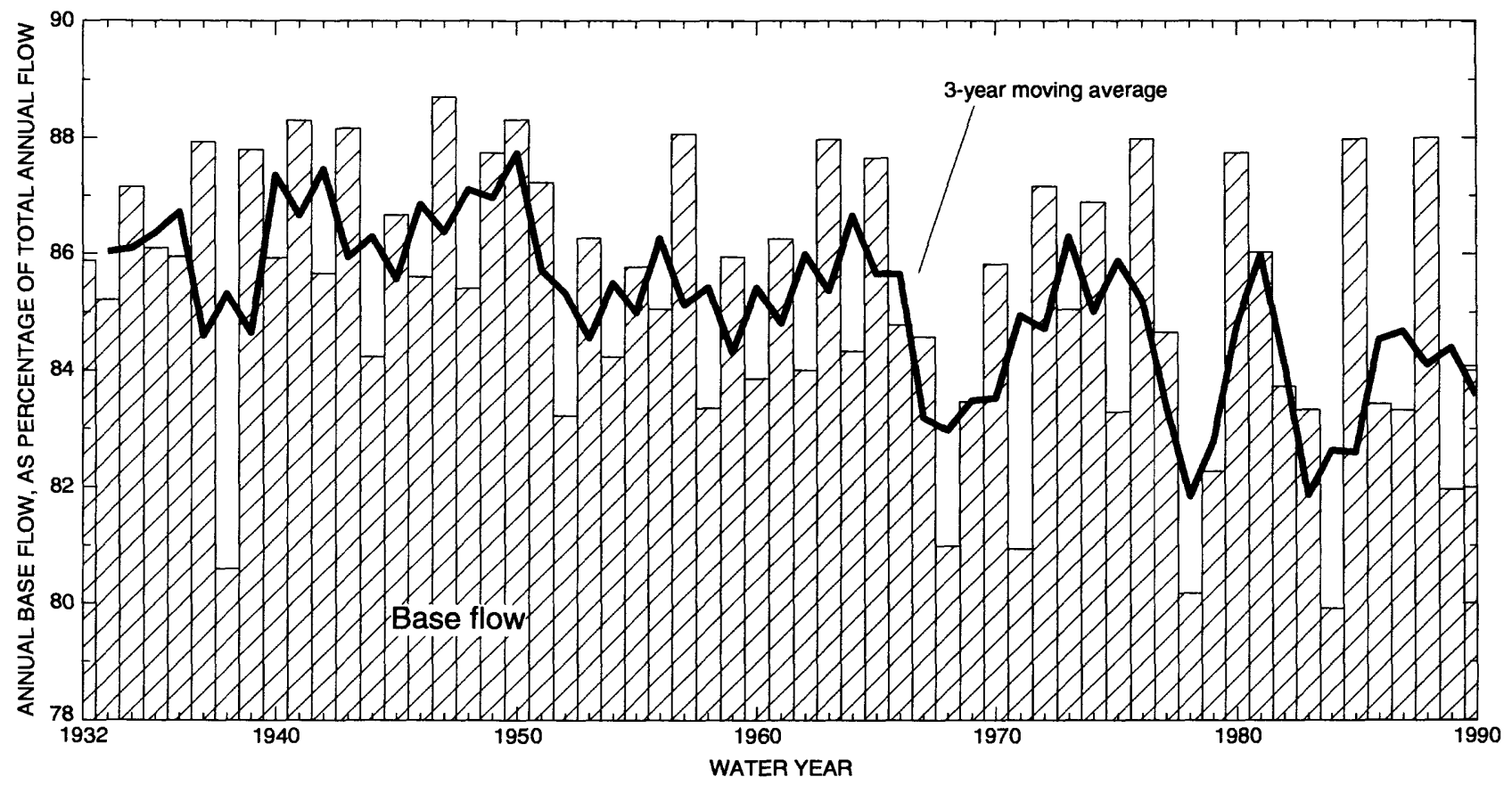

Figure 28. Base flow of the Toms River, N.J., as a percentage of total flow, 1932-90. 
The relation is

$$
\mathrm{C}=37.5+0.75 \mathrm{~L},
$$

where

$\mathrm{C}=$ minimum monthly water level in the Crammer observation well (29-486), in feet below land surface, and

$\mathrm{L}=$ minimum monthly water level in the Lebanon State Forest observation well (5-689), in feet below land surface.

Observed minimum monthly water levels for the Crammer observation well (29-486) and the Lebanon State Forest observation well (5-689), and the minimum monthly water levels for the Crammer observation well as predicted by the above relation, are shown in figure 29. From 1955 to about 1975, observed and predicted water levels in the Crammer observation well agree closely, although the equation slightly overpredicts for some months and slighltly underpredicts for others. During 1975-90, however, the relation between the water levels in these two wells changed, such that the equation no longer predicts the water level in the Crammer observation well with equally high accuracy. It is concluded from this analysis that the water table declined about $2 \mathrm{ft}$ in the area near the Crammer observation well during 1975-90 relative to the area near the Lebanon State Forest observation well and that the relative decline is not solely the result of periods of lower-than-normal precipitation.

\section{Average Ground-Water-Flow Patterns}

Ground-water-flow patterns in the aquifer system are the result of the effects and interactions of many natural and human-induced stresses on the flow system. The following discussion describes the application of the steady-state ground-water-flow model to the analysis of the flow system under average 1980-89 conditions.

Results of simulations of average 1980-89 conditions were compared with those of predevelopment conditions. The locations and average pumping rates of public-supply wells tapping the Kirkwood-Cohansey aquifer system are shown in figure 30. Most of the large withdrawals are near the main stems of the Toms and Metedeconk Rivers. These withdrawals are 100-percent consumptive; most of the study-area population is served by a regional sewage-collection system with an ocean outfall. Changes in water levels resulting from human activities are shown in figure 31. These changes are the result of the combined effects of ground-water withdrawals from the Kirkwood-Cohansey aquifer system, reduced recharge, lowered heads in underlying confined aquifers, and the presence of the Point Pleasant Canal and the Manasquan Reservoir. Water levels declined by $1 \mathrm{ft}$ or more over several large developed areas and near pumping centers. Maximum declines exceeded $10 \mathrm{ft}$ in Point Pleasant Borough near the Point Pleasant Canal and near the major Toms River Water Company wells. Ground-water levels in a small area in the north-central part of the study area rose several feet in response to the filling of the Manasquan Reservoir.

Water-level changes in layer 2 (fig. 32) are similar to those in layer 1 except near the coast, where the deep part of the system is confined and the effects of withdrawals are more pronounced; leakage from shallow water-bearing strata is restricted by overlying silt and clay layers so that withdrawals cause an increased gradient that induces lateral and vertical flow to production wells. A large area of water-level declines of up to $20 \mathrm{ft}$ is centered at Seaside Heights Borough. 

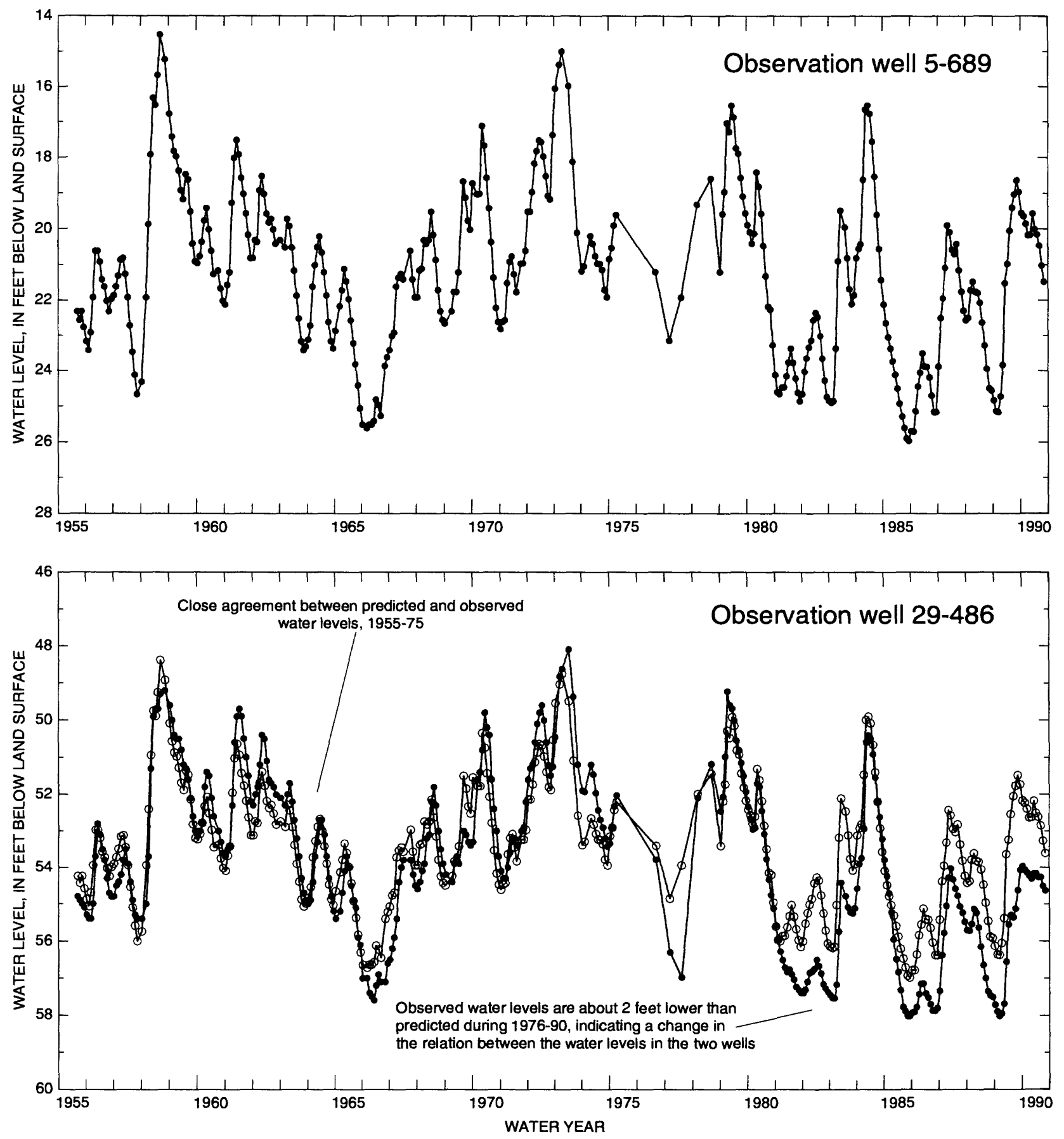

EXPLANATION

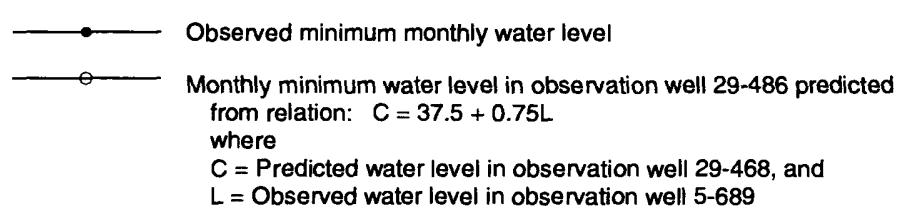

Figure 29. Water levels in observation wells 5-689 and 29-486, and the relation between observed and statistically predicted water levels in observation well 29-486, Toms River, Metedeconk River, and Kettle Creek Basins, New Jersey. (Well locations shown in fig. 2) 


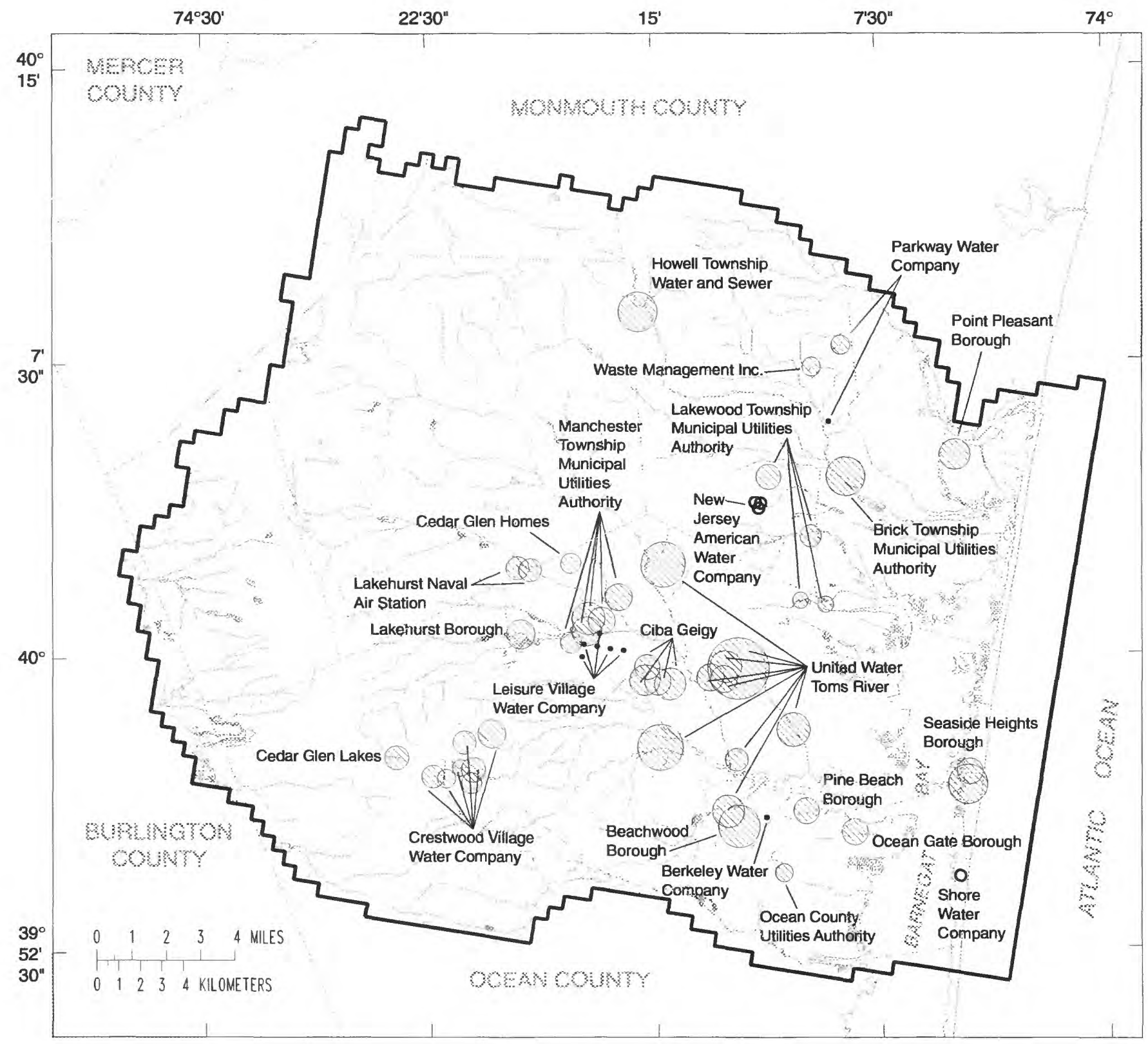

EXPLANATION

Model boundary, layers 1 and 2

Pumpage, in million gallons per day--

- Less than 0.05

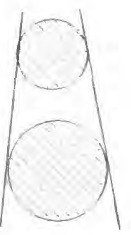

1

2

- Location of purveyor well with no withdrawals for 1989-92

Figure 30. Average recent (1989-92) pumpage of wells tapping the Kirkwood-Cohansey aquifer system in the Toms River, Metedeconk River, and Kettle Creek Basins, New Jersey. 


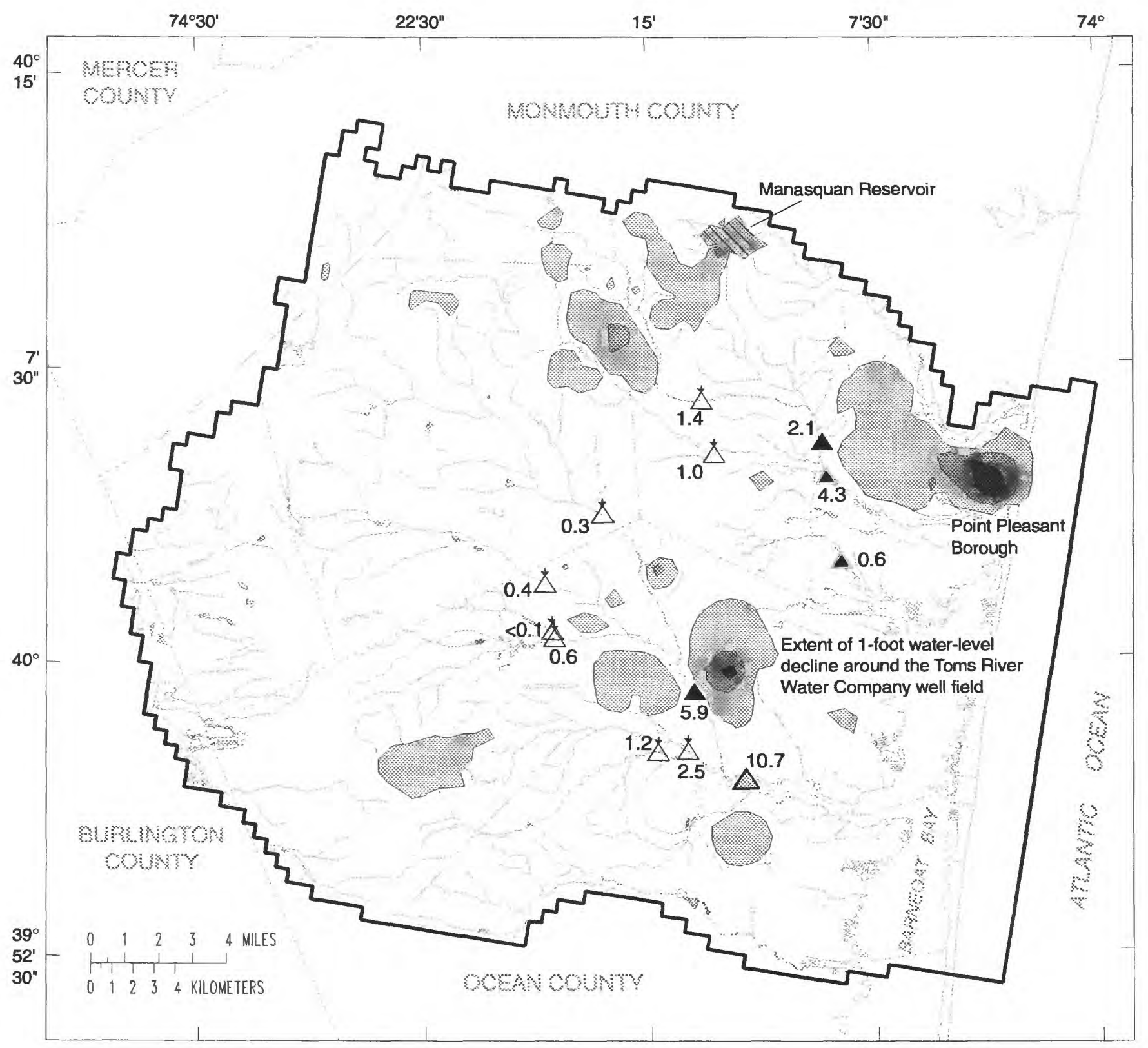

\section{EXPLANATION}

AREA OF WATER-LEVEL CHANGE

Water-level rise in response to filling the Manasquan Reservoir

1- to 5-foot decline

5- to 10-foot decline

10- to 20-foot decline

Model boundary, layer 1
LOCATION OF STREAMFLOW MEASUREMENT-Number is average base-flow reduction, in million gallons per day
2.1 Streamflow-gaging station
$0.4 \searrow$ Low-flow station
$0.6 \triangle$ Head of tide
10.7 Toms River above confluence with Jakes Branch

Figure 31. Simulated water-level changes in model layer 1 and base-flow reduction from predevelopment conditions due to recent withdrawals and changes in land use, Toms River, Metedeconk River, and Kettle Creek Basins, New Jersey. 


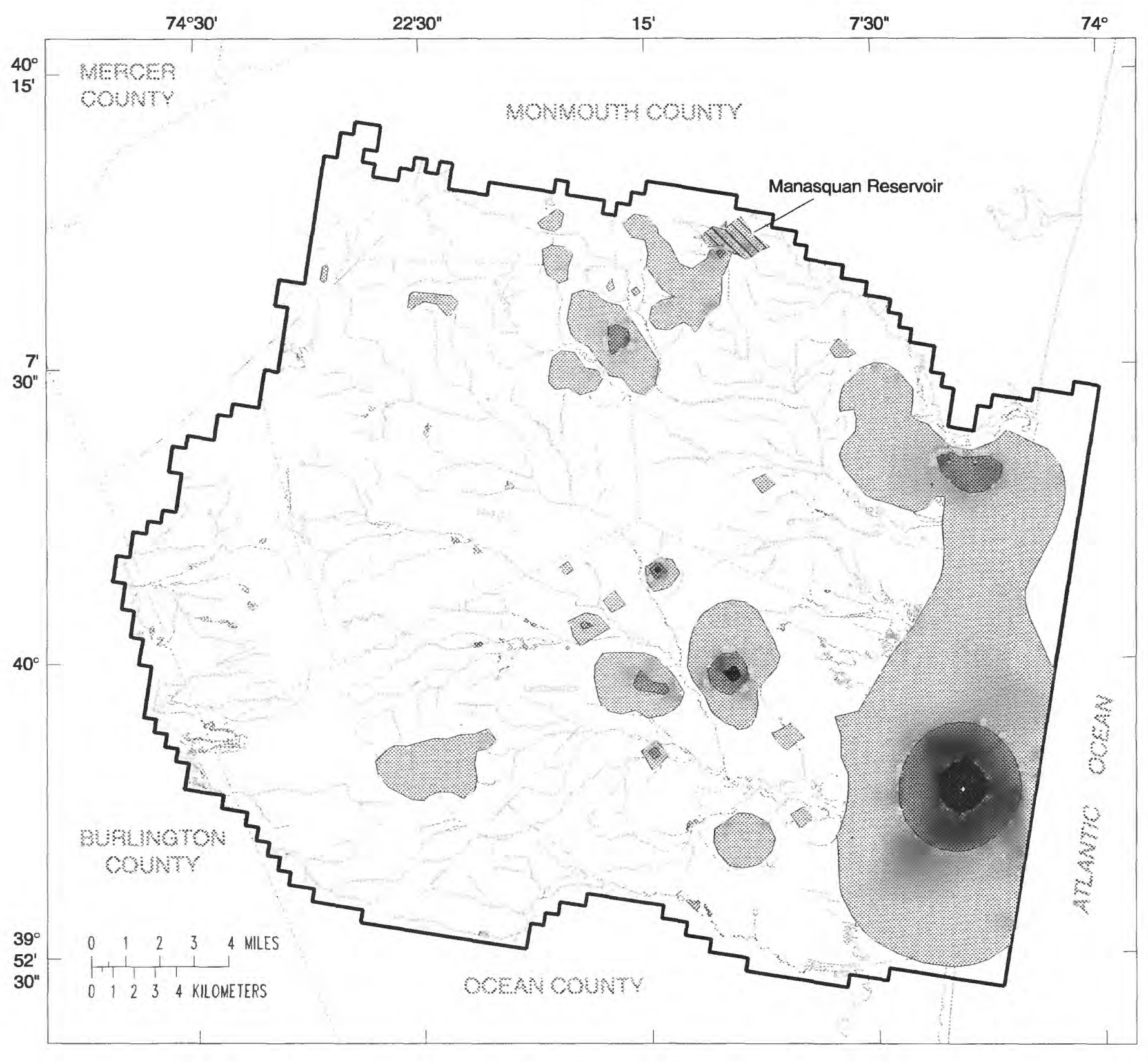

\section{EXPLANATION}

AREA OF WATER-LEVEL CHANGE

Water-level rise in response to fillirig

the Manasquarı Reservoir

1- to 5-foot decline

5- to 10-foot decline

10- to 20-foot decline

Model boundary, layer 2

Figure 32. Simulated water-level changes in model layer 2 from predevelopment conditions due to recent withdrawals and changes in land use in the Toms River, Metedeconk River, and Kettle Creek Basins, New Jersey. 
Depressed water levels in this part of the deep system probably have contributed to the movement of saltwater toward production wells at Seaside Heights Borough. Water-level declines near several other mainland wells are greater in model layer 2 than in layer 1.

Withdrawals from underlying aquifers have increased rates of downward leakage from the unconfined system (fig. 33). In the northwestern part of the study area, vertical flow in some areas near streams has reversed from upward to downward (figs. 24 and 33). In the southeastern part of the study area near the coast, depressed water levels in the underlying Piney Point aquifer also have induced downward flow. Although the area in which the vertical flow direction has reversed is substantial, the amount of induced downward leakage is small owing to the low vertical leakance between the confined and unconfined aquifers in those areas.

Water budgets were compiled for the Toms River, Metedeconk River, and Kettle Creek Basins for both 1980-89 and predevelopment simulations (fig. 34). The largest change from predevelopment conditions in all three basins was in base flow. (In this context, "base flow" refers to ground-water discharge to streams minus infiltration from streams.) The reduction in base flow in the Toms and Metedeconk River Basins can be accounted for by an increase in ground-water withdrawals and a reduction in recharge. Ground-water withdrawals increased most (7.924 Mgal/d) in the Toms River Basin, where 81 percent of the reduction in base flow is attributable to ground-water withdrawals; in the Metedeconk River Basin, only 29 percent of the reduction in base flow is attributable to ground-water withdrawals. Recharge decreased most (2.6 Mgal/d) in the Metedeconk River Basin. Reduced recharge accounts for 63 percent of the reduction in base flow in the Metedeconk River Basin and only 23 percent in the Toms River Basin. The remaining difference in the Toms and Metedeconk River Basin budgets can be accounted for by small increases or decreases in other budget components. In the Kettle Creek Basin, the smallest of the three basins, the reduction in base flow can be accounted for by decreased recharge ( 55 percent), increased ground-water withdrawals ( 24 percent), and decreased inflow from other basins ( 15 percent). The remaining 6 percent can be accounted for by increased outflow to the Toms and Metedeconk River Basins and other adjacent basins and to reduced inflow from the Toms and Metedeconk River Basins.

Simulated base flows for the stations for which average base flow could be estimated from available streamflow data, and for the Metedeconk River, Toms River, and Kettle Creek are listed in table 10. Base-flow reduction was greatest $\left(16.5 \mathrm{ft}^{3} / \mathrm{s}\right)$ in the Toms River. The area contributing flow to the river above the head of tide is larger for the Toms River than for any other stream or tributary in the study area and includes the locations of many ground-water withdrawals and areas where recharge is reduced as a result of urbanization. The last column in table 10 shows values of base-flow reduction as a percentage of predevelopment base flow, which provide a means for evaluating the relative effects of base-flow reduction on streams in the study area. Davenport Branch and Wrangel Brook are the only streams in which base-flow reduction exceeds 10 percent of predevelopment base flow. Base-flow reduction in the North Branch Metedeconk River at Lakewood, N.J. (01408100), and Kettle Creek is nearly 10 percent.

Ground-water withdrawals can divert water from one ground-water basin or subbasin into another. These diversions can cause shifts in the location of ground-water divides that define ground-water subbasins. A flow-path analysis was conducted to identify areas where groundwater divides have shifted in response to ground-water withdrawals. In some areas, recharge follows flow paths that discharge within ground-water basins that are different under 1980-89 conditions than under predevelopment conditions (fig. 35). 


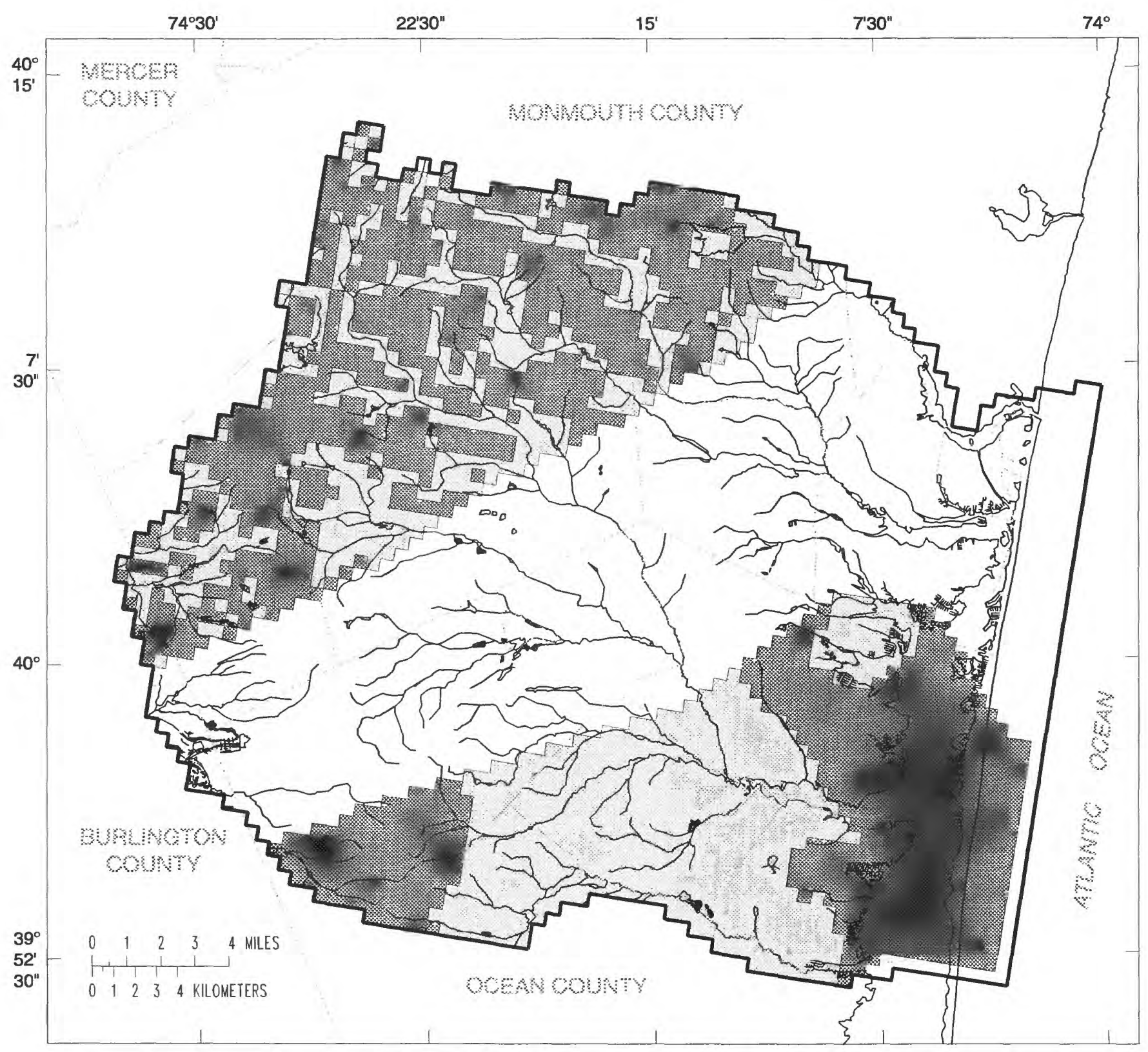

\section{EXPLANATION}

Downward flow

Upward flow

No-flow boundary at bottom of layer 2; no vertical flow present

Model boundary, layer 2

Figure 33. Vertical flow directions across bottom of model layer 2 under recent (1989-92) conditions, Toms River, Metedeconk River, and Kettle Creek Basins, New Jersey. 


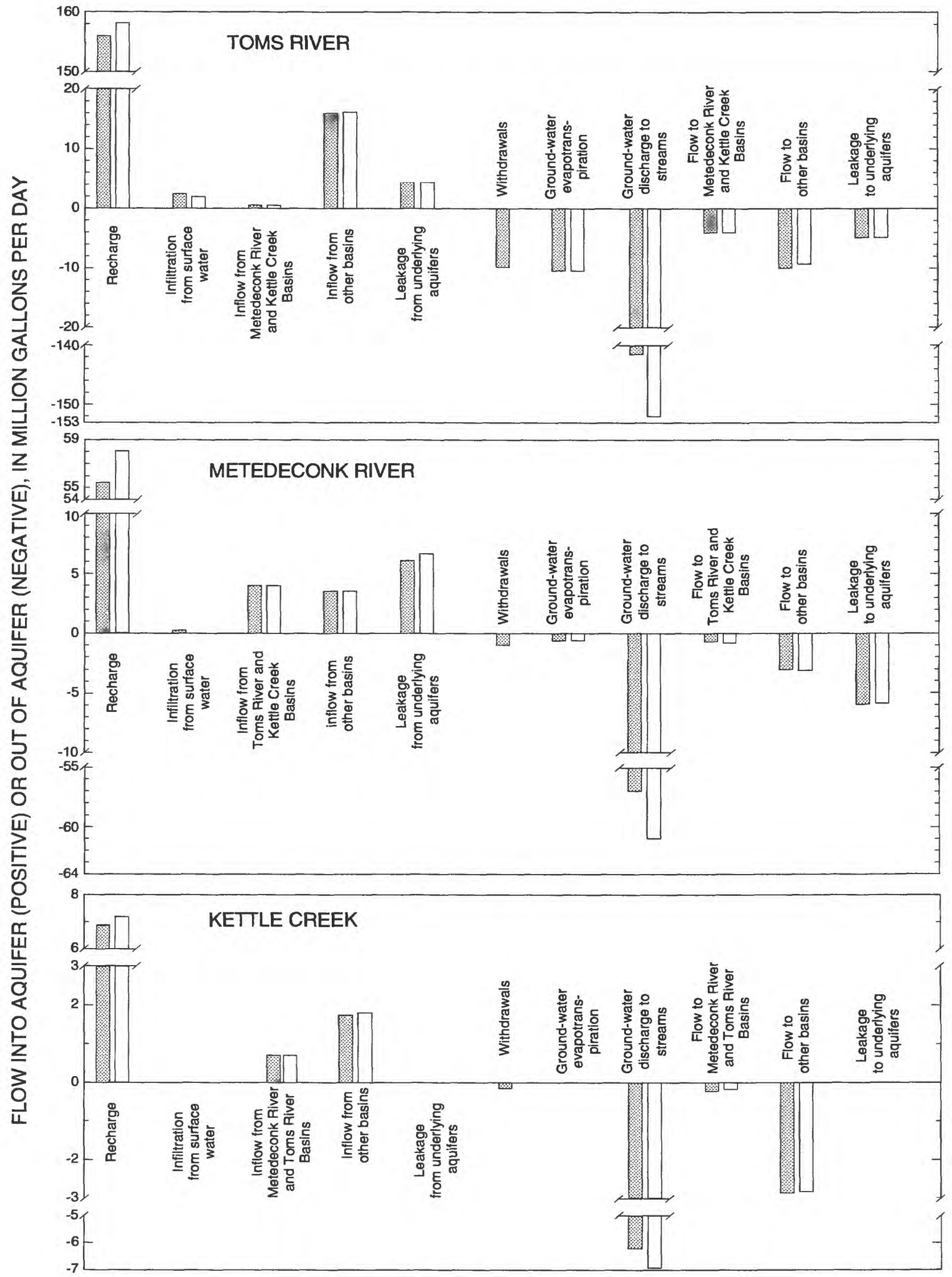

EXPLANATION

Recent conditions

Predevelopment conditions

Figure 34. Predevelopment and recent (1989-92) ground-water budgets for Toms River, Metedeconk River, and Kettle Creek Basins, New Jersey. 
Table 10. Simulated recent base flow and base-flow reduction, Toms River, Metedeconk River, and Kettle Creek Basins, New Jersey

[ $\mathrm{ft}^{3} / \mathrm{s}$, cubic feet per second; $\mathrm{n} / \mathrm{a}$, not available; streamflow-gaging-station locations shown in fig. 2]

\begin{tabular}{|c|c|c|c|c|c|}
\hline $\begin{array}{l}\text { Streamflow- } \\
\text { gaging-station } \\
\text { number }\end{array}$ & $\begin{array}{l}\text { Streamflow- } \\
\text { gaging station } \\
\text { name }\end{array}$ & $\begin{array}{l}\text { Simulated } \\
\text { average } \\
\text { predevelop- } \\
\text { ment base } \\
\text { flow, } \\
\text { in } \mathrm{f}^{3} / \mathrm{s}\end{array}$ & $\begin{array}{c}\text { Simulated } \\
\text { average } 1980- \\
89 \text { base flow, } \\
\text { in } \mathrm{ft}^{3} / \mathrm{s}\end{array}$ & $\begin{array}{l}\text { Base-flow } \\
\text { reduction, } \\
\text { in } \mathrm{ft}^{3} / \mathrm{s}\end{array}$ & $\begin{array}{l}\text { Base-flow } \\
\text { reduction, } \\
\text { in percent of } \\
\text { average } \\
\text { predevelop- } \\
\text { ment base flow }\end{array}$ \\
\hline 01408100 & $\begin{array}{l}\text { North Branch } \\
\text { Metedeconk } \\
\text { River at } \\
\text { Lakewood, N.J. }\end{array}$ & 25.0 & 22.8 & 2.2 & 8.8 \\
\hline 01408120 & $\begin{array}{l}\text { North Branch } \\
\text { Metedeconk } \\
\text { River near } \\
\text { Lakewood, N.J. }\end{array}$ & 44.2 & 40.9 & 3.3 & 7.5 \\
\hline 01408140 & $\begin{array}{l}\text { South Branch } \\
\text { Metedeconk } \\
\text { River at } \\
\text { Lakewood, N.J. }\end{array}$ & 36.9 & 35.4 & 1.5 & 4.1 \\
\hline $\mathrm{n} / \mathrm{a}$ & $\begin{array}{l}\text { Metedeconk } \\
\text { River at head of } \\
\text { tide }\end{array}$ & 94.4 & 87.8 & 6.6 & 7.0 \\
\hline $\mathrm{n} / \mathrm{a}$ & $\begin{array}{l}\text { Kettle Creek at } \\
\text { head of tide }\end{array}$ & 10.6 & 9.6 & 1.0 & 9.4 \\
\hline 01408300 & $\begin{array}{l}\text { Toms River at } \\
\text { Whitesville, N.J. }\end{array}$ & 54.6 & 54.1 & .5 & .9 \\
\hline 01408440 & $\begin{array}{l}\text { Union Branch at } \\
\text { Lakehurst, N.J. }\end{array}$ & 35.4 & 34.5 & .9 & 2.5 \\
\hline 01408460 & $\begin{array}{l}\text { Manapaqua } \\
\text { Brook at } \\
\text { Lakehurst, N.J. }\end{array}$ & 7.2 & 7.1 & .1 & 1.4 \\
\hline 01408490 & $\begin{array}{l}\text { Ridgeway } \\
\text { Branch near } \\
\text { Lakehurst, N.J. }\end{array}$ & 35.4 & 34.8 & .6 & 1.7 \\
\hline 01408500 & $\begin{array}{l}\text { Toms River near } \\
\text { Toms River, N.J. }\end{array}$ & 171.6 & 162.5 & 9.1 & 5.3 \\
\hline 01408600 & Wrangel Brook & 34.7 & 30.9 & 3.8 & 11.0 \\
\hline 01408630 & $\begin{array}{l}\text { Davenport } \\
\text { Branch }\end{array}$ & 16.1 & 14.1 & 2.0 & 12.4 \\
\hline $\mathrm{n} / \mathbf{a}$ & $\begin{array}{l}\text { Toms River above } \\
\text { confluence with } \\
\text { Jakes Branch }\end{array}$ & 231.8 & 215.3 & 16.5 & 7.1 \\
\hline
\end{tabular}




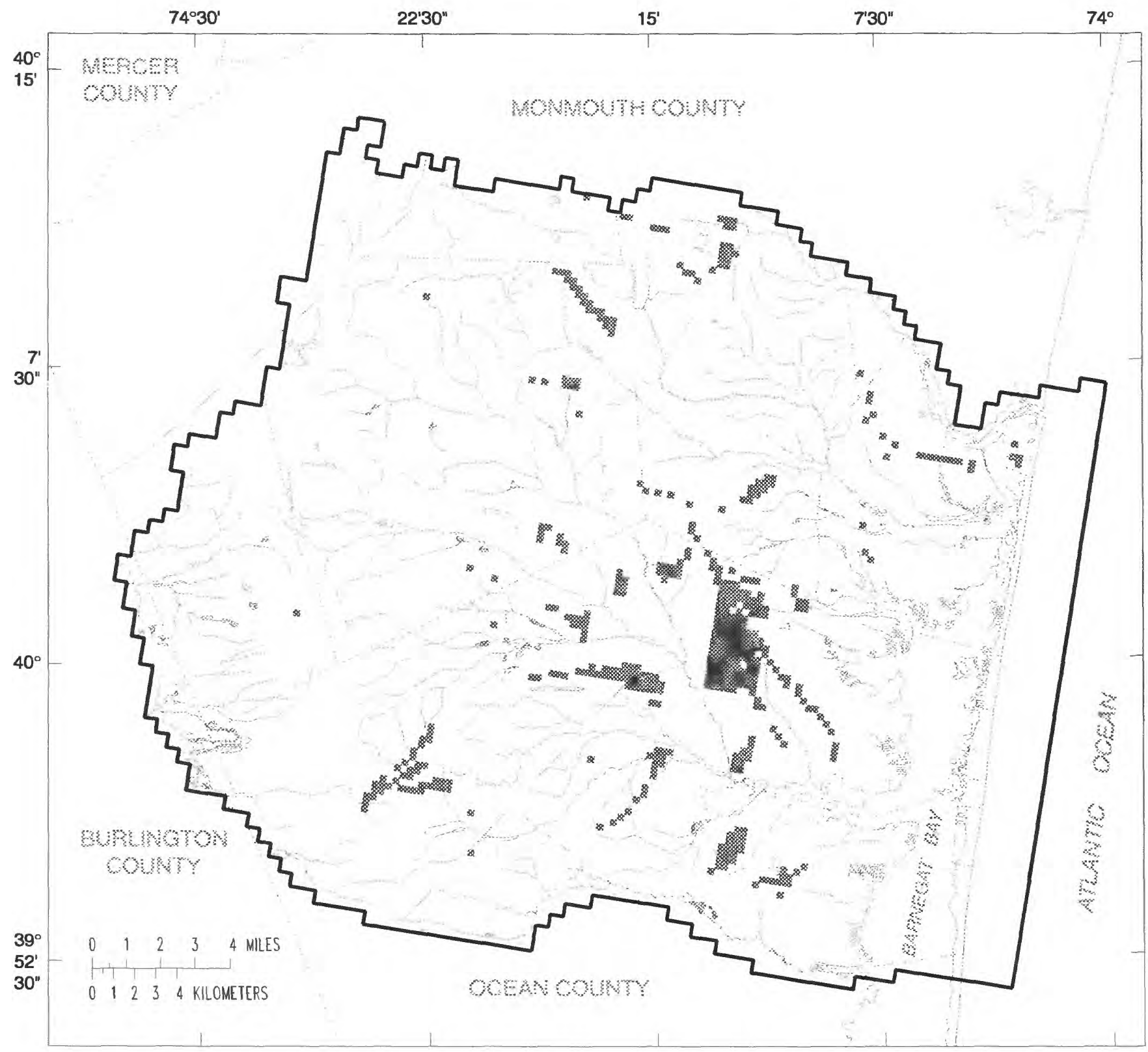

\section{EXPLANATION}

Area in which location of ground-water divide has changed. (Ground-water recharge in these areas discharges to a different stream than under predevelopment conditions, or to a well)

Model boundary, layer 1

Figure 35. Areas in which location of ground-water divide has changed from predevelopment conditions, Toms River, Metedeconk River, and Kettle Creek Basins, New Jersey. 


\section{Seasonal Variations}

Recent (1989-92) conditions were simulated for a typical 12-month cycle by using the same pattern of seasonal variation in recharge that was used in simulations of predevelopment conditions (as described in previous sections of this report). In this simulation, however, withdrawals were included to represent actual recent monthly withdrawals as closely as possible. For each public-supply well, respective monthly withdrawals during 1989-92 were averaged to obtain the average recent withdrawal for each month. This approach preserves the historical pattern of withdrawals for each individual well while minimizing the effects of any anomalous withdrawals that may have occurred during any single month during 1989-92. These historical pumping patterns provide a baseline for projections of future withdrawals, which are discussed in a subsequent section of this report.

Average withdrawals during 1989-92 ranged from about $11 \mathrm{Mgal} / \mathrm{d}$ in February to about $21 \mathrm{Mgal} / \mathrm{d}$ in July (fig. 36). Seasonal variations in pumpage from public-supply wells near the coast tended to be greater than those from wells farther inland.

Simulated predevelopment and recent water levels near a major pumping center about 1.5 mi east of the Toms River streamflow-gaging station (01408500), where average water-levels have declined about $15 \mathrm{ft}$ (fig. 31), are shown in figure 37. The hydrograph of water levels under recent conditions illustrates the seasonal variations in water-level declines near major publicsupply wells. The difference between predevelopment and recent water levels at this location is greatest during April and May when pumping rates are high and is least during November when pumping rates are lower. In others areas, the difference between predevelopment and recent water levels may be greatest at other times of the year, depending on the operating schedules of particular wells.

Simulated mean monthly base flows of the Toms and Metedeconk Rivers under recent conditions are shown in figures $38 \mathrm{a}$ and $38 \mathrm{~b}$, respectively, along with predevelopment base flows. Simulated base-flow reduction for the two streams is shown as a separate ordinate in figures 38c and 38d, respectively. Reduction of the Toms River remains close to the average of about $16 \mathrm{ft}^{3} / \mathrm{s}$, reaching a minimum of $14.1 \mathrm{ft}^{3} / \mathrm{s}$ in November and a maximum of $16.3 \mathrm{ft}^{3} / \mathrm{s}$ in March. Reduction of the Metedeconk River fluctuates between a minimum of $5.6 \mathrm{ft}^{3} / \mathrm{s}$ in November and a maximum of $7.7 \mathrm{ft}^{3} / \mathrm{s}$ in May.

Seasonal variations in base-flow reduction in a particular stream are highly dependent on seasonal variations in ground-water withdrawals in and near upstream parts of the basin. Another (perhaps less intuitive) factor affecting seasonal variation in base-flow reduction is the cyclic addition and release of water to and from aquifer storage. Changes in aquifer storage occur as recharge and ground-water-ET rates oscillate. In order to investigate the role of seasonal variations in recharge and ground-water-ET rates on the effects of withdrawals, an experimental, transient-flow condition was simulated in which recharge and ground-water ET varied seasonally, but hypothetical withdrawal stresses were kept constant. The withdrawal stresses were kept constant in order to isolate the effects of seasonal variations in recharge and ground-water ET. 


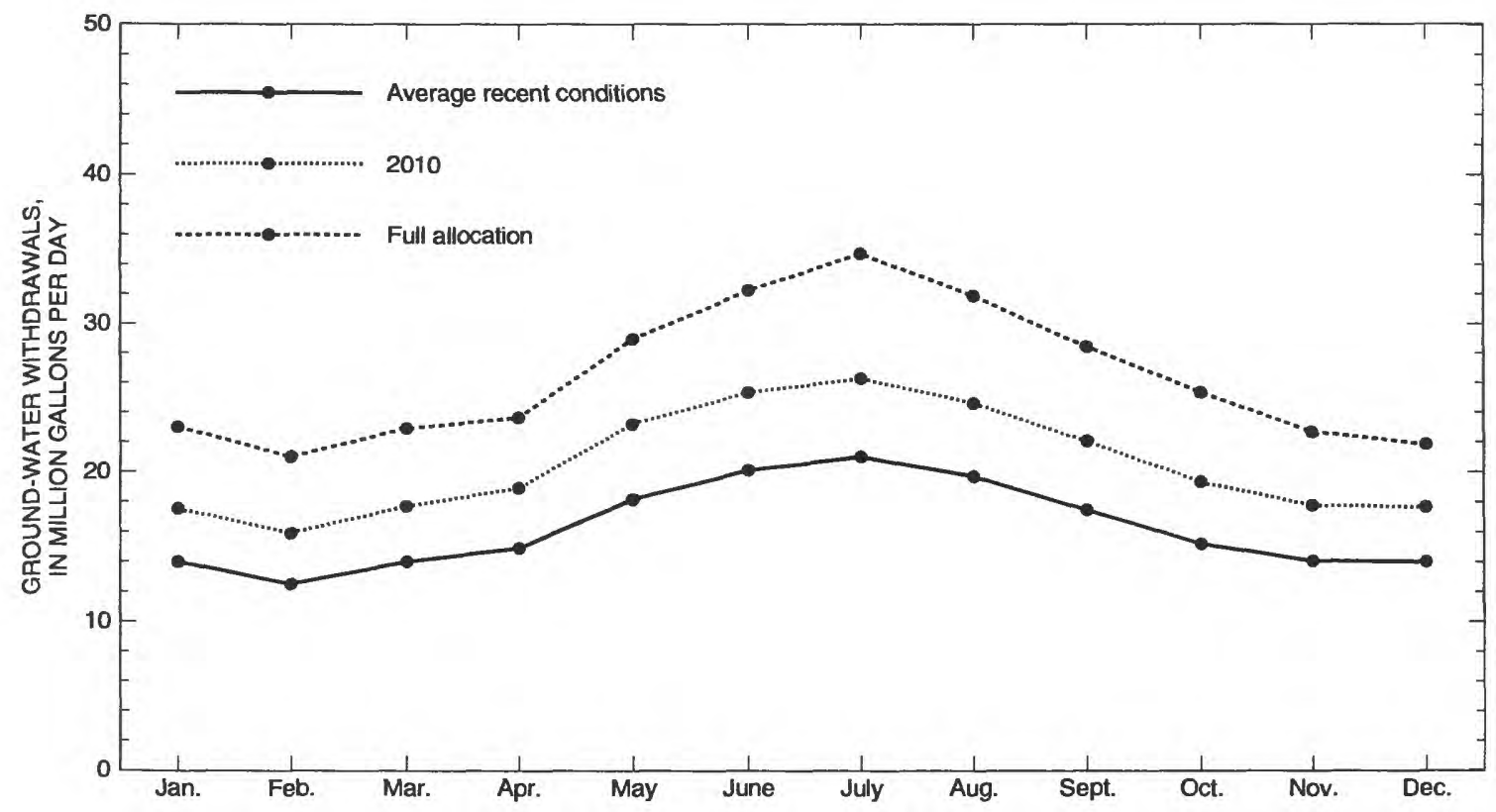

Figure 36. Recent (1989-92) and projected monthly ground-water withdrawals, Toms River, Metedeconk River, and Kettle Creek Basins, New Jersey. 


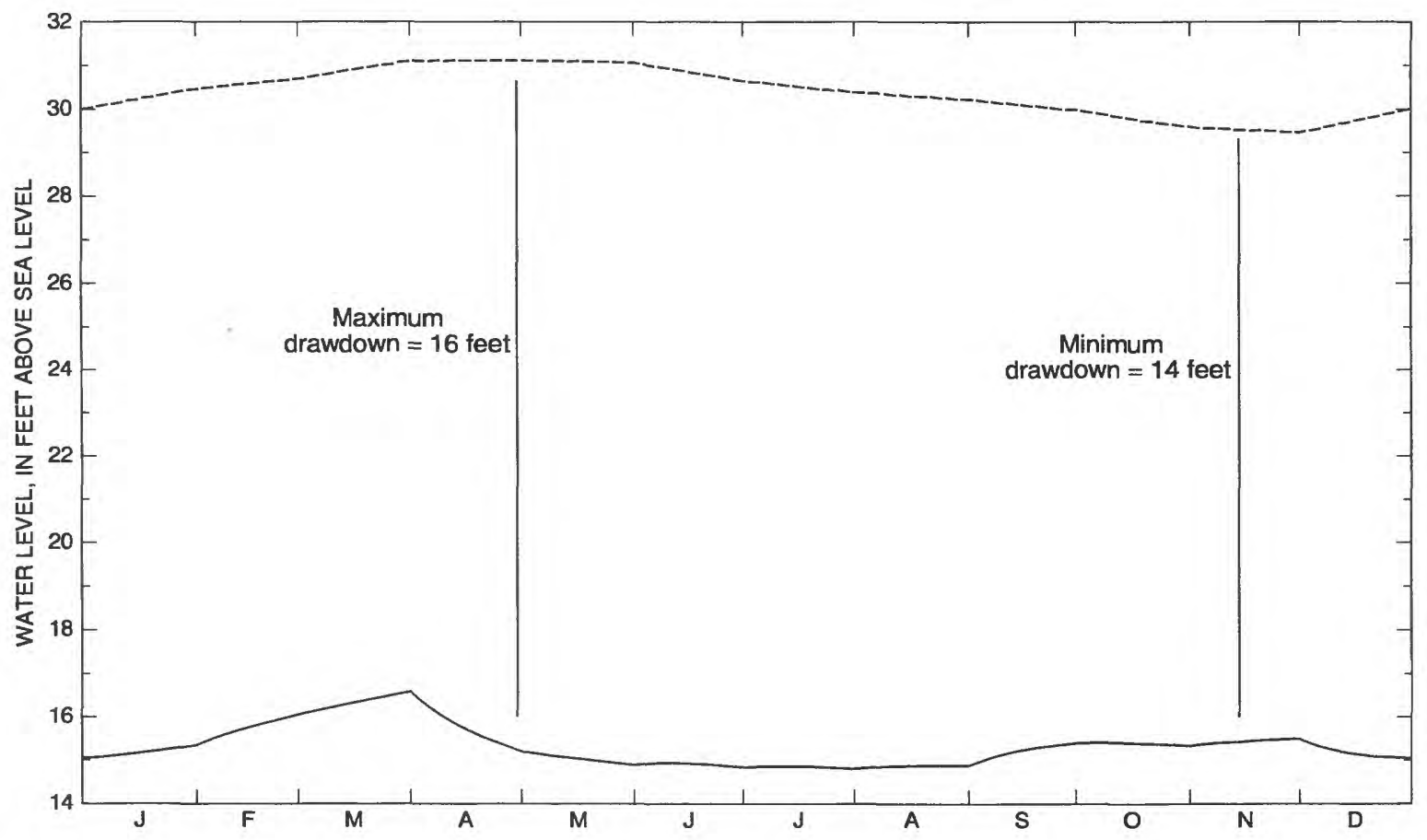

\section{EXPLANATION}

\section{Predevelopment conditions}

Recent conditions--withdrawals from nearby wells

Figure 37. Simulated water levels at model cell (layer, row, column) $=(1,38,51)$ near Toms River Water Company, N.J., pumping center under predevelopment and recent (1989-92) conditions. (Model-cell location shown in fig. 7) 

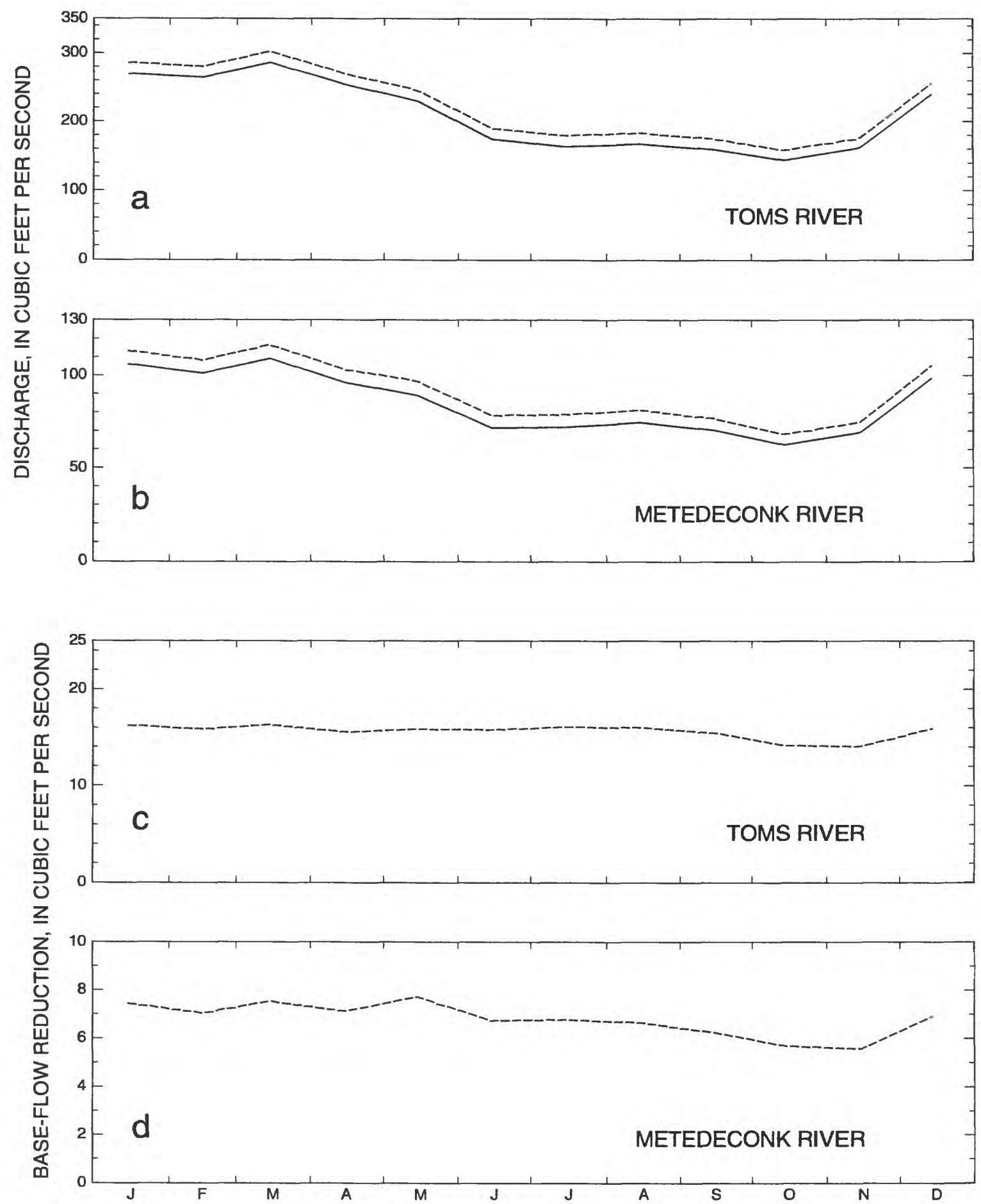

EXPLANATION

Mean monthly base flow, 1989-92

Predevelopment base flow

Figure 38. Simulated typical monthly base flow under predevelopment and recent conditions of the (a) Toms River and (b) Metedeconk River; and monthly base-flow reduction for the (c) Toms River and (d) Metedeconk River, N.J. 
In this experiment, a 12-month seasonal cycle was simulated by using the same rates of recharge and ground-water ET used to describe predevelopment conditions. Ten hypothetical public-supply wells, each pumping at a rate of $0.65 \mathrm{Mgal} / \mathrm{d}\left(1 \mathrm{ft}^{3} / \mathrm{s}\right)$, were situated throughout the Toms River Basin (fig. 39a). Initial conditions were generated through a steady-state simulation. The cyclic 12-month system response was simulated repeatedly until a stable response was obtained.

Results of this simulation of hypothetical conditions were compared with the 12-month system response with no withdrawals (predevelopment conditions). Monthly changes in base flow at the Toms River near Toms River, N.J. (01408500), streamflow-gaging station resulting from the constant withdrawals were determined (fig. 39b). Monthly base-flow reduction resulting from a particular set of withdrawal stresses is defined as the difference between the amount of base flow occurring during a given month and the amount of base flow that would have occurred during that month in the absence of that set of withdrawal stresses. Graphically then, the difference between the two curves for a given month represents base-flow reduction for that month. These differences representing monthly reduction are shown as a separate ordinate in figure 39c. Average reduction is about $7.9 \mathrm{ft}^{3} / \mathrm{s}$. Reduction is greater during high-flow conditions (about 8.5 $\mathrm{ft}^{3} / \mathrm{s}$ in March) and smaller during low-flow conditions (about $7.3 \mathrm{ft}^{3} / \mathrm{s}$ in October).

Although the seasonal variation in base-flow reduction in this hypothetical example is small, other simulations showed that this variation can be greater if recharge is more variable. For example, results of similar simulations in which recharge is assumed to be 0 during May through September indicate that reduction resulting from the hypothetical, constant $10-\mathrm{ft}^{3} / \mathrm{s}$ withdrawals could range from about $6 \mathrm{ft}^{3} / \mathrm{s}$ to about $10 \mathrm{ft}^{3} / \mathrm{s}$.

Seasonal variations in base-flow reduction resulting from a constant withdrawal stress can be explained by the variation in rates of flow into and out of aquifer storage near pumped wells through the year and the concomitant changes in the hydraulic gradient at an adjacent stream. During periods of low or no recharge, water is released from storage to provide flow to the wells. Because the wells are located at a distance from the stream, however, the effect of this storage release on the hydraulic gradient at the stream/aquifer interface is delayed; that is, the lowering of the water-table gradient at the stream in response to pumping is delayed. Consequently, the diversion of ground-water flow to the wells rather than the stream is attenuated, and base-flow reduction is less than the average annual reduction. The delaying effect of aquifer-storage release on discharge to streams is discussed in greater detail by Jenkins (1968). During periods of high recharge, some water that would flow to the stream in the absence of pumping instead replaces the water previously released from storage to supply the well, and the lowering of the water-table gradient at the stream in response to pumping is accentuated. Consequently, base-flow reduction is greater than the average annual reduction. The results of this experiment indicate, therefore, that seasonal variations in the effects of withdrawals on base-flow reduction are a consequence of both the seasonal fluctuation in pumping rate and aquifer-storage effects.

\section{Uncertainty in Predicted Effects of Withdrawals}

As discussed previously in the presentation of the steady-state-model calibration, different combinations of model-parameter values could result in an acceptable calibration. Nonuniqueness of the model calibration raises issues of uncertainty in model-predicted effects of withdrawals. Although uncertainty in predictive simulations is difficult to quantify, alternative models in which 


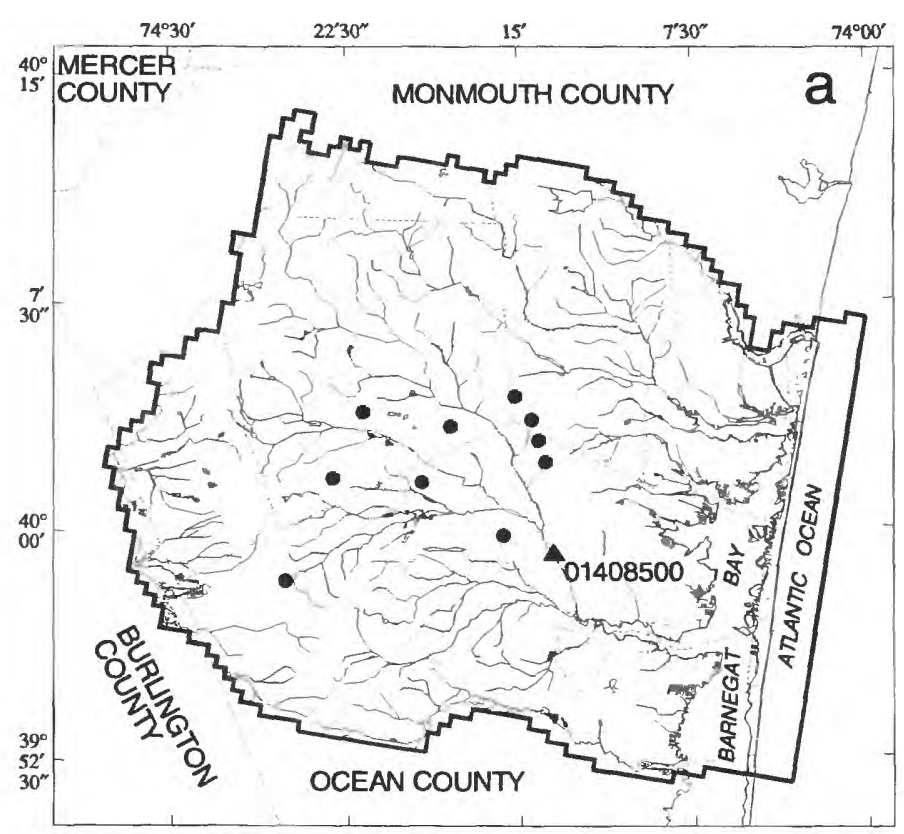

\section{EXPLANATION}

Model boundary, layers 1 and 2

- Pumped well

- Streamflow-gaging station 01408500, Toms River near Toms River, N.J.
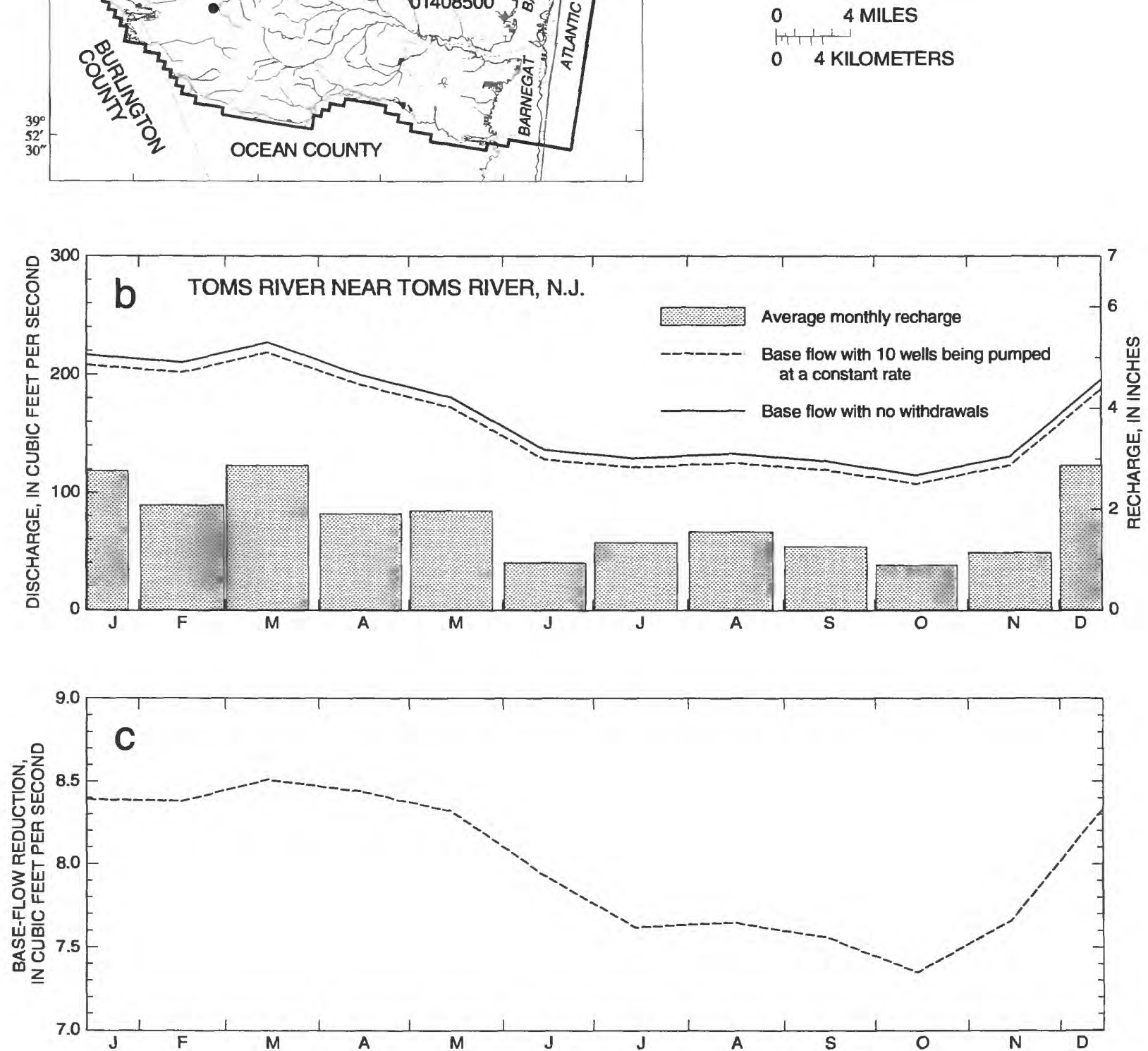

Figure 39. (a) Locations of 10 hypothetical pumped wells; (b) average monthly recharge and base flow; and (c) average monthly reduction in base flow of the Toms River near Toms River, N.J. (01408500), in response to the constant withdrawal of 1 cubic foot per second from each of the wells. 
selected different combinations of parameter values are used can be tested to indicate the reliability of the predictions. Although an exhaustive uncertainty evaluation was beyond the scope of this study, a limited analysis was conducted.

Several alternative models of the flow system were developed by changing the values of one or two model parameters within a plausible range. The alternative models were then used to simulate the system's response to 1980-89 withdrawal rates in the same manner as the calibrated model. The alternative models were not recalibrated; water levels and (or) flows simulated with the alternative models are different (in some cases, substantially different) from those simulated with the calibrated model. However, the alternative models are considered to represent an example realm of identically parameterized and discretized models that might reasonably represent the system. By comparing responses of the alternative models to the same changes in withdrawal stress, the reliability of predicted responses of the calibrated model can be inferred. Uncertainties resulting from the scale of discretization and from the selected parameterization are not addressed.

As described earlier, tests show that hydraulic-conductivity and recharge sensitivities are inversely correlated; increasing the rate of recharge has the same effect on head distribution as decreasing bydraulic conductivity. As a result, alternative models in which both recharge rates and hydraulic-conductivity values are either increased or decreased produce similar distributions of head, but produce different rates of base flow to streams. Alternative models were tested in which both recharge rates and hydraulic-conductivity values were either increased or decreased by a factor of 1.5 . The areas over which simulated water-level declines are $1 \mathrm{ft}$ or more, centered around the Toms River Water Company pumping center in Dover Township, were compared. The area estimated with the calibrated model (see fig. 31) covers about $5.5 \mathrm{mi}^{2}$. If recharge rates and hydraulic conductivity are decreased by a factor of 1.5 , the area covers almost $15 \mathrm{mi}^{2}$. If recharge rates and hydraulic conductivity are increased by a factor of 1.5 , the area is only about $4 \mathrm{mi}^{2}$ (fig. 40a). These results indicate that the extent of water-level changes in excess of $1 \mathrm{ft}$ could be substantially underestimated as a consequence of offsetting errors in estimates of recharge and hydraulic conductivity, but that the extent probably is not substantially overestimated.

A similar analysis of estimated values of streambed conductance shows that if values of streambed conductance are overestimated, the extent of simulated water-level declines of $1 \mathrm{ft}$ or more is greater than the extent simulated with the calibrated model (fig. 40b). Therefore, the extent of model-estimated water-level changes in excess of $1 \mathrm{ft}$ could be underestimated as a consequence of errors in estimated values of streambed conductance.

Simulated base-flow reduction also was tested by using these alternative models (fig. 40c). Results show that model estimates of average base-flow reduction made by using alternative models with higher or lower recharge rates and hydraulic conductivities differ only slightly from those made by using the calibrated model. Values of base-flow reduction expressed as a percentage of average 1980-89 base flow range from 6.7 to 8.5 percent for the Toms River and from 5.1 to 9.7 percent for the Metedeconk River. Therefore, calibrated-model estimates of reduction probably are not substantially over- or underestimated as a consequence of offsetting errors in estimates of recharge and bydraulic conductivity. 

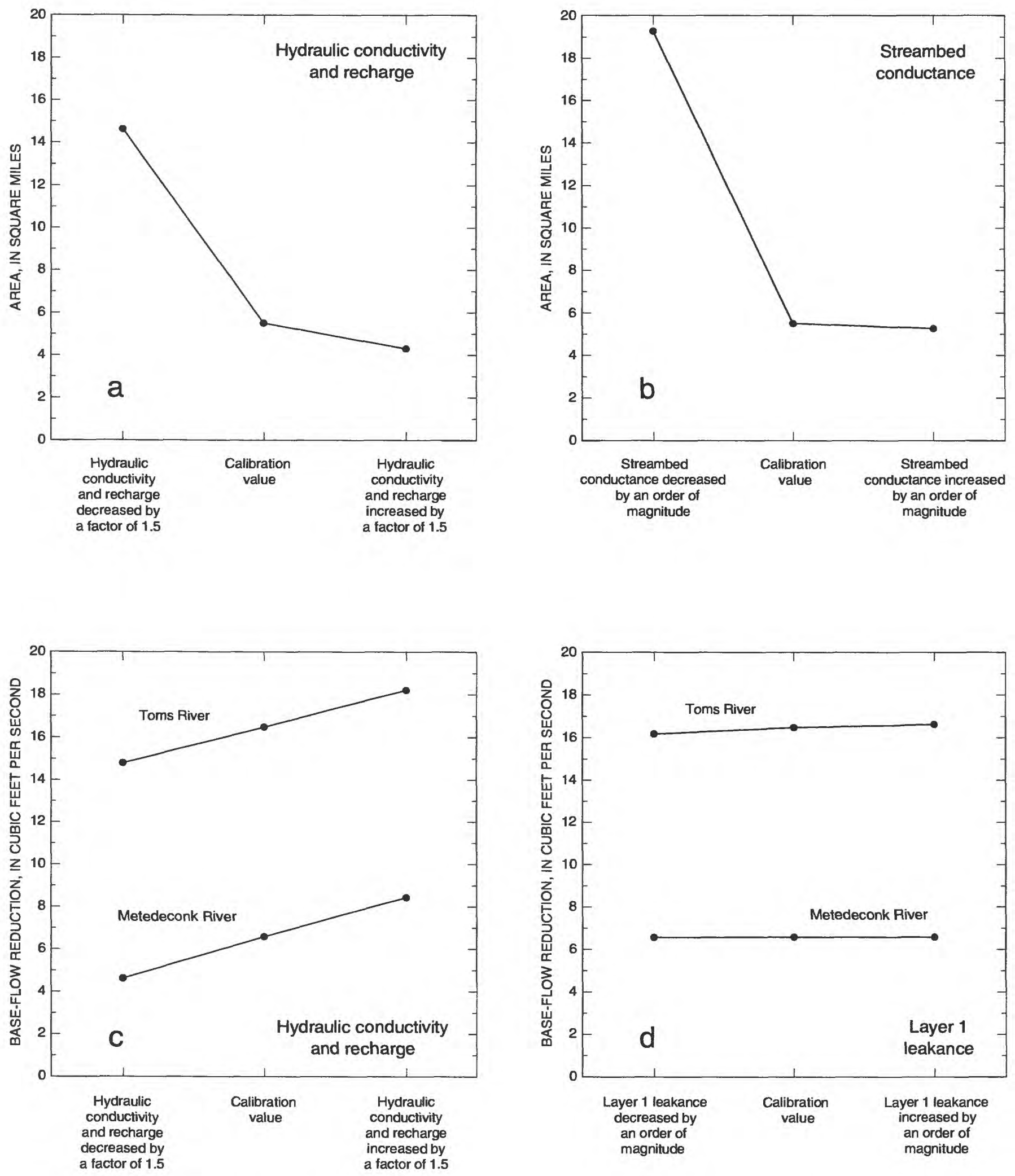

Figure 40. Sensitivity of zone of influence of Toms River Water Company, N.J., pumping center to changes in (a) hydraulic conductivity and recharge and (b) streambed conductanc; and sensitivity of simulated base-flow reduction in the Toms River and Metedeconk River, N.J., to changes in (c) hydraulic conductivity and recharge and (d) layer 1 leakance. (Well-field location shown in fig. 31. Zone of influence defined as area with at least 1 foot of drawdown) 
Tests of alternative models in which values of vertical leakance between layers 1 and 2 (fig. 40d) were higher and lower than those used in the calibrated model show that the accuracy of estimates of vertical leakance is less important in predictions than the accuracy of estimates of other parameters.

The uncertainty in estimates of specific yield as a controlling factor in water-level changes was investigated by using two alternative models that incorporate the effects of higher and lower values of specific yield. The alternative models used values of specific yield that are 1.5 times lower and higher, respectively, than that used in the calibrated model and that are considered to bracket the plausible range in this parameter for this aquifer system. When values of specific yield were decreased, water levels changed more; when values of specific yield were increased, water levels changed less. However, the uncertainty in the seasonal variation in water-level changes that results from uncertainty in estimates of specific yield is small in relation to average water-level changes.

These same alternative models, with the high and low specific-yield values, were used to investigate the uncertainty inherent in estimates of seasonal variations in base-flow reduction at five stream locations. Base-flow-reduction patterns at the stream sites differed as a result of differences in seasonal variations in withdrawals among wells located in and near each of the five respective subbasins (fig. 41). The reliability of estimates of seasonal variations in base-flow reduction, however, is not seriously limited by the uncertainty in estimates of aquifer-storage properties.

\section{SIMULATED EFFECTS OF ADDITIONAL GROUND-WATER WITHDRAWALS}

The calibrated model was used to simulate the hydrologic effects of additional groundwater withdrawals under two water-supply-development alternatives. The first alternative represents ground-water withdrawals projected for the year 2010 from estimates of water demand reported in the New Jersey Statewide Water Supply Master Plan (WSMP) (CH2M Hill and others, 1993, Task 3 Report). The second alternative represents conditions that could occur if current water allocations were fully used by water-supply purveyors and self-supplied water users in the study area. Hydrologic effects of projected increases in withdrawals under both alternatives were estimated for both average and seasonal conditions.

\section{Limitations of Predictive Simulations}

Predictive simulations of future hydrologic conditions are subject to two categories of uncertainty: (1) uncertainty in the projection of the location, magnitude, and seasonality of future withdrawal stresses, and (2) uncertainty in the model representation of the ground-water system. Uncertainty in projections of future stresses is difficult to assess because many of the factors-economic, demographic, political, and cultural--that will shape future withdrawal stresses are beyond the realm of hydrologic analysis. The projections of additional withdrawals presented in the following section are derived from the WSMP and information provided by the NJDEP, Bureau of Water Allocation (Scott Tyrrell, New Jersey Department of Environmental Protection, written commun., 1994). 

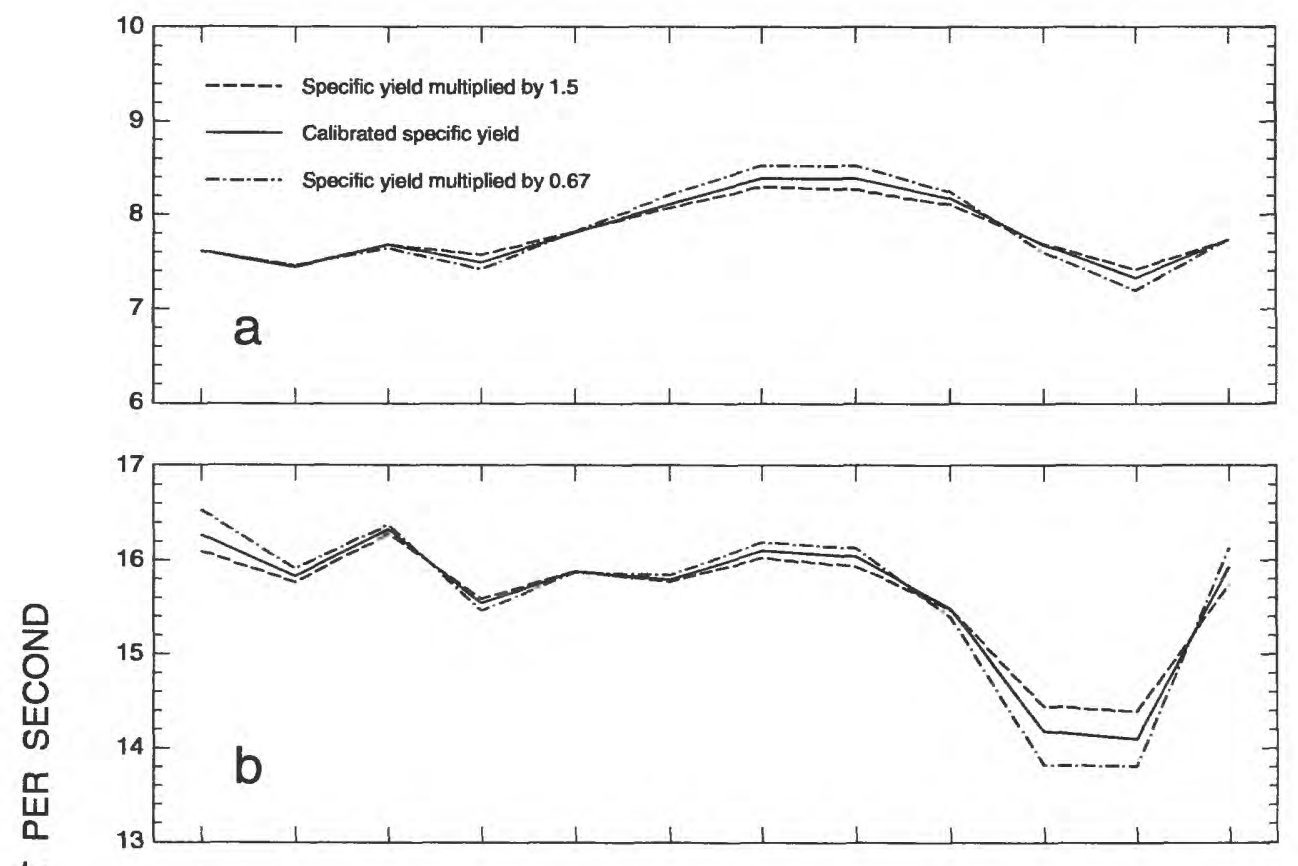

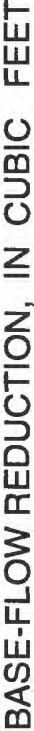
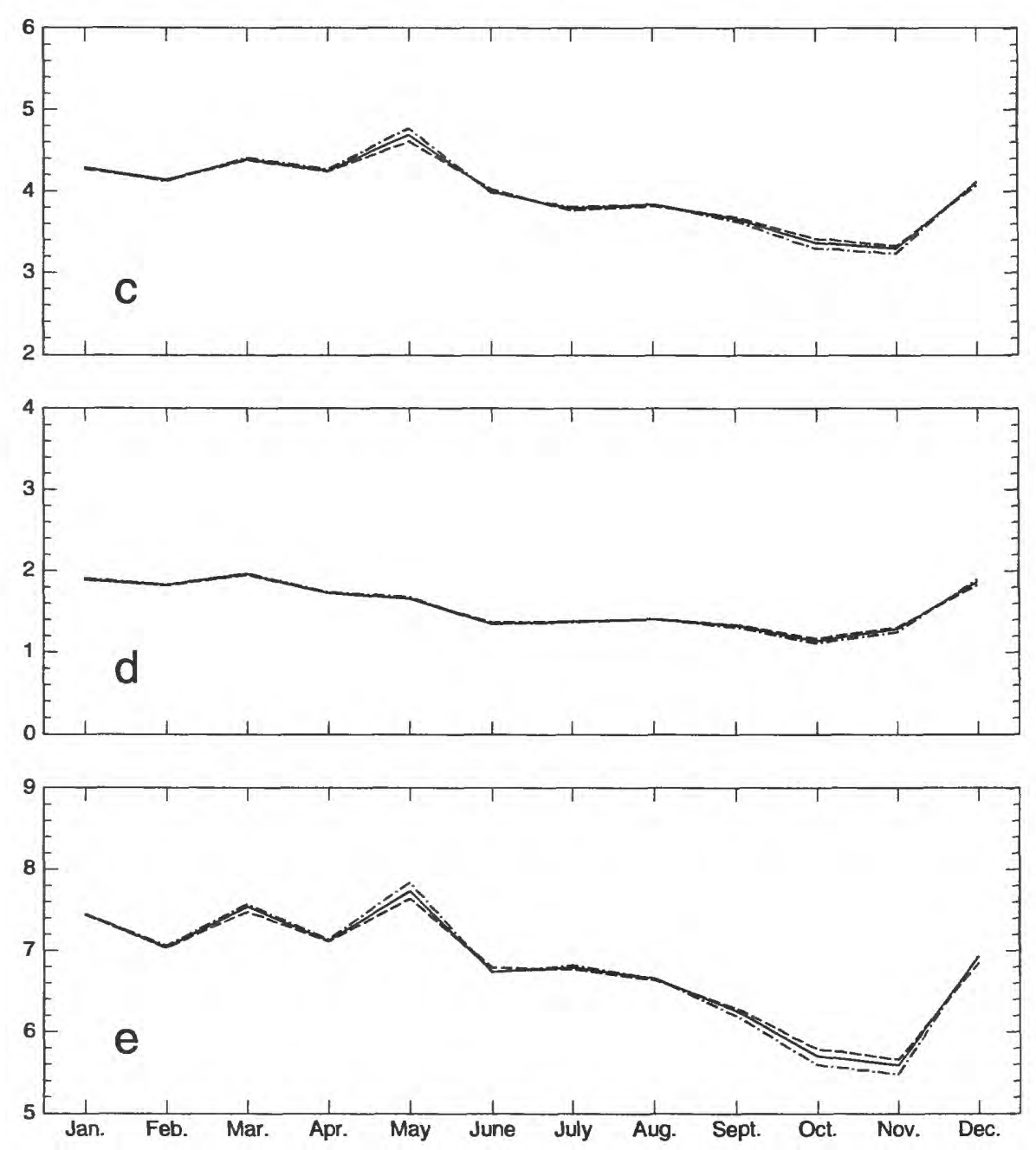

Figure 41. Sensitivity of predicted monthly base-flow reduction to changes in specific yield at five streamflow-gaging stations: (a) Toms River near Toms River, N.J.; (b) Toms River; (c) North Branch Metedeconk River near Lakewood, N.J.; (d) South Branch Metedeconk River at Lakewood, N.J.; (e) Metedeconk River. (Each y-axis scale spans 4 cubic feet per second; streamflow-gaging-station locations shown in fig. 2) 
Specific uncertainties in the model representation of the aquifer system were described previously. Predictions of the hydrologic effects of additional ground-water withdrawals are subject to the same sources of uncertainty, many of which are difficult to quantify. Simulated hydrologic effects presented here must be viewed with appropriate regard for the limitations inherent in modeling techniques.

\section{Projected Increases in Withdrawals}

Ground-water-withdrawal projections for the first alternative (2010 alternative) were guided by projections of total water demand in the WSMP (CH2M Hill and others, 1993, Task 3 Report). The present study area corresponds with two of the Regional Water Resource Planning Areas (PA's) listed in the WSMP: Planning Area 15 (Metedeconk River watershed) and Planning Area 16 (Toms River watershed). Total water demand for these two PA's was estimated in the WSMP for 1990 and was projected for various planning horizons, including 2010. Total-waterdemand estimates listed in the WSMP represent water withdrawn from all water sources including unconfined aquifers, confined aquifers, surface water, and water imported from other areas. Estimated total water demand for these two areas for 1990 is $53.2 \mathrm{Mgal} / \mathrm{d}$, and the projected demand for these two areas for 2010 is $67.7 \mathrm{Mgal} / \mathrm{d}$, an increase of 27 percent (CH2M Hill and others, 1993, Task 3 Report, table 5-1).

It is assumed for the present analysis that by 2010 ground-water withdrawals from the Kirkwood-Cohansey aquifer system also will have increased to 27 percent above the average rate of withdrawals during 1989-92. Ground-water withdrawals from the Kirkwood-Cohansey aquifer system during 1989-92 totaled $15.55 \mathrm{Mgal} / \mathrm{d}$, so projected average withdrawals for 2010 are $19.75 \mathrm{Mgal} / \mathrm{d}$ (15.55 Mgal/d x 1.27). Two water purveyors, Seaside Heights and Point Pleasant Beach, withdrew water at rates that were at or near their respective allocations during 1989-92, and their ability to use the Kirkwood-Cohansey aquifer system has been constrained by the presence of elevated chloride concentrations in pumped water. Because this situation makes additional withdrawals by these purveyors from the Kirkwood-Cohansey aquifer system unlikely, those withdrawals are projected to remain stable. The projected withdrawals of several other users also were adjusted upward or downward to reflect recent trends in withdrawals. Water users in the study area are listed in table 11, along with average reported withdrawals for 1989-92 and projected withdrawals for 2010 . Wells supplying the projected increases in withdrawals are assumed to be at or near the locations of existing public-supply wells; therefore, figure $\mathbf{3 0}$ provides a general indication of the distribution of the increases.

The development of the second alternative of ground-water withdrawals (full-allocation alternative) is more complicated because the various water users are currently withdrawing ground water at rates that are different percentages of their respective allocations. Therefore, fullallocation withdrawals may translate to a 0-percent increase for one purveyor, a 50-percent increase for another, and even an 800-percent increase for another. The percentage increase for each respective water user was determined by using the following equation:

where

$$
P_{(i)}=\frac{\left(A_{t(i)}-W_{t(i)}\right)}{W_{t(i)}} \times 100,
$$

$\mathbf{P}_{(\mathrm{i})}=$ increase in Kirkwood-Cohansey aquifer system withdrawals by purveyor (i) when operating at full allocation, in percent;

$A_{t(i)}=$ total ground-water allocation for purveyor (i), in Mgal/d; and

$\mathrm{W}_{\mathrm{t}(\mathrm{i})}=$ total ground-water withdrawals by purveyor (i) from all aquifers in 1990, in Mgal/d. 
Table 11. Projected increases in ground-water withdrawals for 2010 and full-allocation alternatives, Toms River, Metedeconk River, and Kettle Creek Basins, New Jersey

[NJDEP, New Jersey Department of Environmental Protection; Mgal/d, million gallons per day; Inc., Incorporated; Co., Company; MUA, Municipal Utilities Authority; -, data unavailable; *, no increase projected; ** increase projected on basis of recent use patterns; <, less than]

\begin{tabular}{|c|c|c|c|c|c|c|}
\hline $\begin{array}{l}\text { NJDEP } \\
\text { water- } \\
\text { allocation } \\
\text { permit } \\
\text { number }\end{array}$ & $\begin{array}{l}\text { Purveyor } \\
\text { name }\end{array}$ & $\begin{array}{l}\text { Average 1989- } \\
92 \text { withdrawals } \\
\text { from Kirkwood- } \\
\text { Cohansey } \\
\text { aquifer system } \\
\text { (Mgal/d) }\end{array}$ & $\begin{array}{l}1994 \text { ground- } \\
\text { water } \\
\text { allocation } \\
\text { (Mgal/d) }\end{array}$ & $\begin{array}{c}\text { Projected } \\
\text { withdrawals } \\
\text { for } 2010 \\
\text { alternative } \\
\text { (Mgal/d) }\end{array}$ & $\begin{array}{l}\text { Increase in } \\
\text { withdrawals from } \\
\text { Kirkwood-Cohansey } \\
\text { aquifer system under } \\
\text { full-allocation } \\
\text { alternative } \\
\text { (percent) }\end{array}$ & $\begin{array}{l}\text { Projected } \\
\text { withdrawals } \\
\text { under full- } \\
\text { allocation } \\
\text { altemative } \\
\text { (Mgal/d) }\end{array}$ \\
\hline 2176p & Cibs-Geigy & 0.06 & 4.30 & 0.07 & 100 & 0.11 \\
\hline $2197 p$ & Waste Disposal & .01 & .25 & .01 & 113 & .02 \\
\hline 2316 & Redi-Flow, Inc. & .01 & 0 & 0 & - & 0 \\
\hline $2396 p$ & Leisure Village Water Co. & .02 & .39 & .02 & 119 & .04 \\
\hline $2411 p$ & $\begin{array}{l}\text { Ocean County Utilities } \\
\text { Authority }\end{array}$ & .01 & .014 & .02 & 38 & .02 \\
\hline 5000 & Toms River Water Ca. & 2.32 & 11.5 & 2.95 & 66 & 3.85 \\
\hline 5001 & Toms River Water Ca. & 4.64 & $\begin{array}{l}\text { (combined with per- } \\
\text { mit 5000) }\end{array}$ & 5.89 & $\mathbf{0}$ & 4.64 \\
\hline 5036 & Cedar Glen Lakes Water Co. & .16 & .38 & .20 & 138 & .38 \\
\hline 5043 & Manchenter Townuhip MUA & 1.53 & 2.18 & 1.94 & 43 & 2.18 \\
\hline 5078 & N.J. American Water Co. & .01 & 3.16 & $.20 *$ & 6,800 & .69 \\
\hline 5079 & Lakewood Townahip MUA & .46 & 4.23 & .59 & 176 & 1.27 \\
\hline 5093 & Seaside Heights & .74 & 1.23 & $.74 *$ & 0 & $.74 *$ \\
\hline 5150 & Point Pleasant Borough & .46 & 2.22 & .58 & 20 & .55 \\
\hline 5172 & Brick Township & .62 & 5.10 & .79 & 720 & 5.10 \\
\hline 5184 & Perkway Water Co. & .42 & .62 & .54 & 44 & .61 \\
\hline 5212 & Beachwood Borough & .67 & .99 & .85 & 29 & .86 \\
\hline 5218 & Ocean Gate Water Co. & .23 & .27 & .29 & 20 & .27 \\
\hline 5230 & Berkeley Water Co. & .53 & .67 & .68 & 26 & .67 \\
\hline 5231 & Crestwood Village Water Co. & 1.05 & 1.33 & 1.33 & 27 & 1.33 \\
\hline 5252 & Pine Beacb Borough & .20 & .25 & .25 & 28 & .25 \\
\hline 5262 & Lakehurst Borough & .31 & .49 & .39 & 53 & .47 \\
\hline 5265 & $\begin{array}{l}\text { Howell Township Water and } \\
\text { Sewer }\end{array}$ & .23 & 2.37 & $.60 *$ & 0 & $.23 *$ \\
\hline 5288 & Shore Water Co. & $<.01$ & .26 & $<.01$ & 48 & $<.01$ \\
\hline 5297 & $\begin{array}{l}\text { Point Pleasant Beach } \\
\text { Borough }\end{array}$ & .76 & .75 & $.76 *$ & 0 & $.76 *$ \\
\hline 5348 & Cedar Glen Homes & .08 & .21 & .10 & 136 & .18 \\
\hline \multirow[t]{2}{*}{5366} & $\begin{array}{l}\text { Lakehurst Naval Air } \\
\text { Engineering Station }\end{array}$ & .03 & .54 & .04 & 1,333 & .43 \\
\hline & TOTAL & 15.55 & 48.32 & 19.83 & 65 & 25.66 \\
\hline
\end{tabular}


Implicit in this approach is the assumption that each purveyor will continue to withdraw the same percentage of total withdrawals from the Kirkwood-Cohansey aquifer system. Exceptions to this assumption are noted in table 11. If withdrawals from deep confined aquifers are restricted in the future, reliance on the Kirkwood-Cohansey aquifer system could increase more than is projected under this alternative. Percentage increases in ground-water withdrawals under the full-allocation alternative, calculated by using the equation above, and projected average withdrawals for each purveyor under the full-allocation alternative are listed in table 11. Projected average withdrawals under the full-allocation alternative total $25.66 \mathrm{Mgal} / \mathrm{d}$, which represents a 65-percent increase above 1989-92 withdrawal rates of $15.55 \mathrm{Mgal} / \mathrm{d}$. According to the WSMP (CH2M Hill and others, 1993, Task 3 Report, table 5-1), the projected total water demand for the study area (PA's 15 and 16) would increase by about 88 percent from the 1990 level by 2040. Therefore, the full-allocation alternative can be viewed as a long-term projection. The distribution of projected average increases in withdrawals is shown in figure 42 . The largest projected increase (5.1 Mgal/d) is for Brick Township Municipal Utilities Authority, which operates a well field near the Metedeconk River.

Projected withdrawals listed in table 11 were used in steady-state simulations to predict the effects of additional withdrawals on average water levels, base flows, and flow patterns. Effects of seasonal variations in withdrawals were determined through transient simulations of a typical 12-month seasonal cycle, necessitating the calculation of projected monthly withdrawals at each pumping center. These monthly withdrawals were calculated by increasing the 4-year (1989-92) average monthly withdrawal for each well by an amount appropriate for the alternative. In the case of the 2010 alternative, the average monthly withdrawal for most wells was increased by 27 percent. For the full-allocation alternative, the average monthly withdrawal for each well was increased by the percentage listed in table 11 for the water-allocation permittee. By following this procedure, the historical pattern of seasonal pumping variability for each public-supply well is maintained in the projections of monthly withdrawals; that is, it is assumed that additional withdrawals will fluctuate seasonally according to historical patterns. Seasonal variations in recent and projected withdrawals are shown in figure 36.

\section{Average Conditions}

The response of the hydrologic system to the 2010 alternative was less dramatic than the response to the full-allocation alternative. Water levels in layer 1 would decline about 1 to $5 \mathrm{ft}$, and only in several small areas (fig. 43). Declines would be greatest near the Toms River Water Company and Point Pleasant Borough pumping centers. Under the full-allocation alternative (fig. 44), water levels would decline from 1 to $20 \mathrm{ft}$, predominantly in the Metedeconk River Basin and between the Metedeconk and Manasquan River Basins. Water levels also would decline from 1 to $5 \mathrm{ft}$ in small areas near the Manchester Township and Cedar Glen Lakes pumping centers in the Toms River Basin (locations in fig. 30). Additional withdrawals from Lakewood Municipal Utilities Authority and Point Pleasant Borough wells (locations in fig. 30) would lower water levels from 1 to $5 \mathrm{ft}$. Water levels would decline most in the Metedeconk River Basin, in the area of the Parkway Water Company (location in fig. 30). Water levels in this large area would decline as much as $20 \mathrm{ft}$ because the aquifer is thinner and is composed of lower permeability sediments than elsewhere in the study area. Additional withdrawals near streams would result in only minor water-level declines over small areas. 


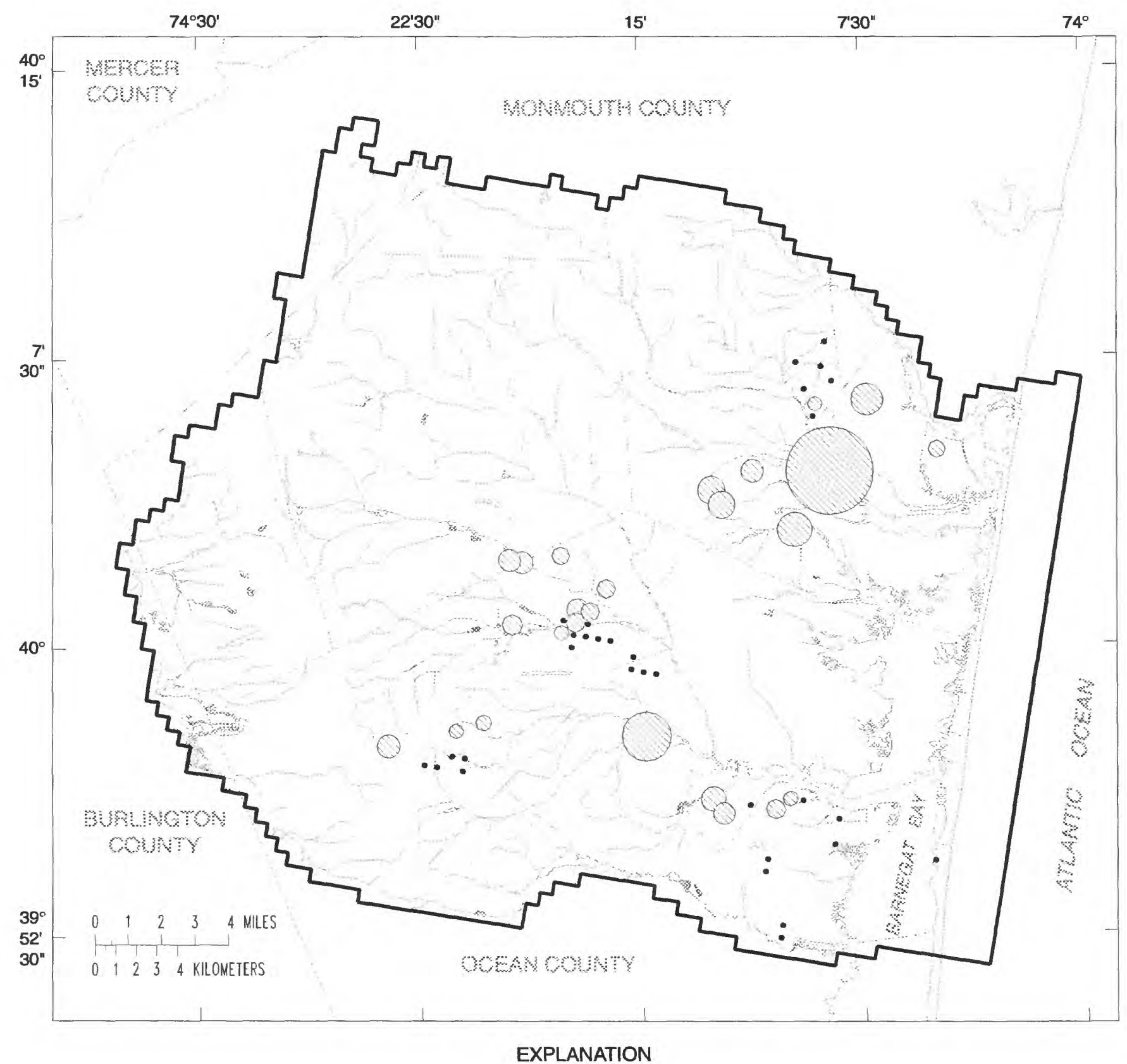

EXPLANATION

Model boundary, layers 1 and 2

Pumpage, in million gallons per day

- Less than 0.05

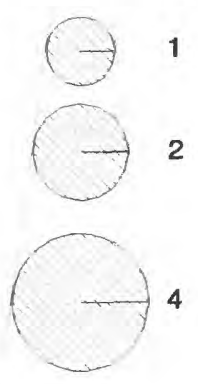

Figure 42. Projected increases in pumpage from the Kirkwood-Cohansey aquifer system at full allocation, Toms River, Metedeconk River, and Kettle Creek Basins, New Jersey. 


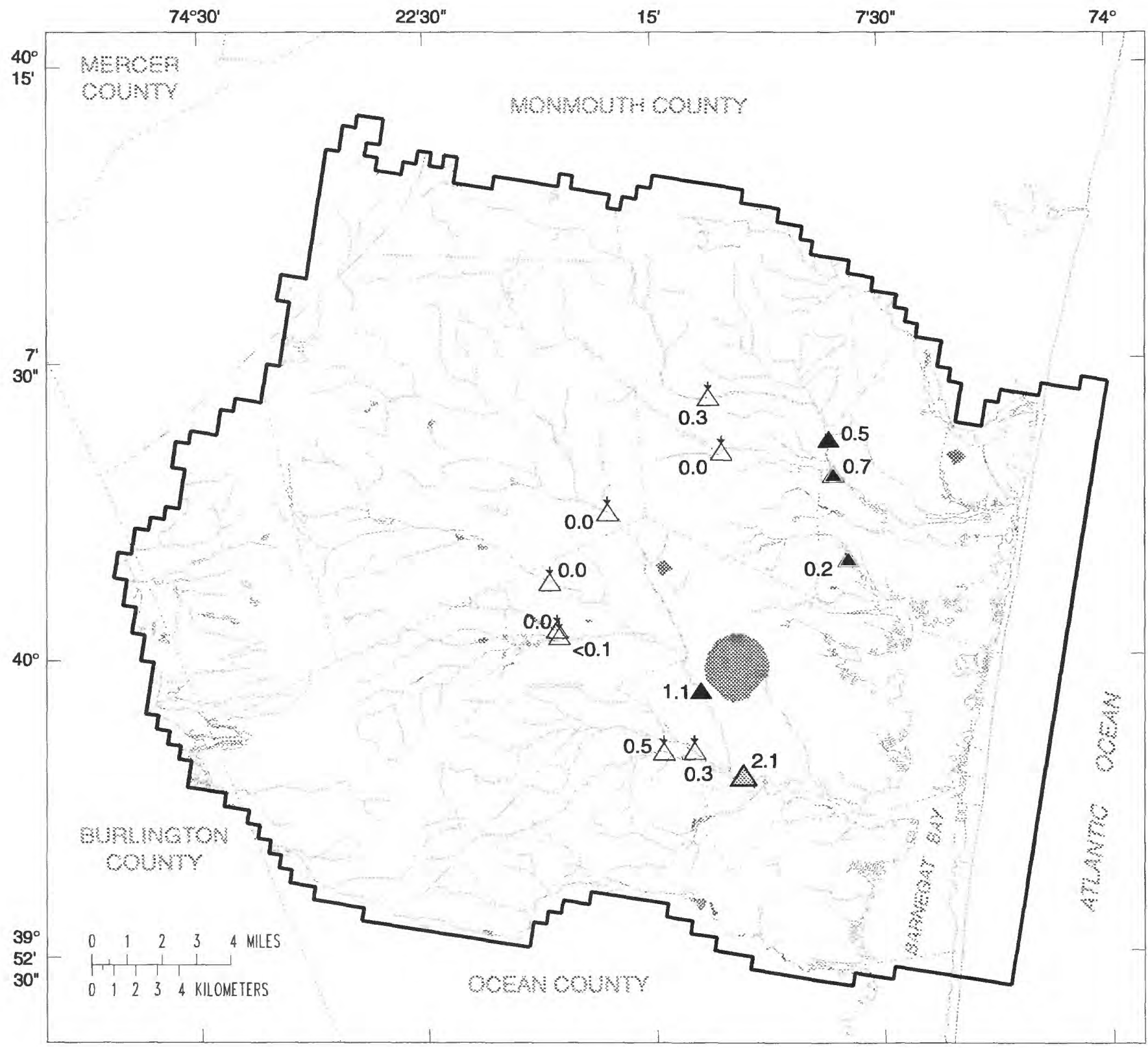

EXPLANATION

AREA OF WATER LEVEL DECLINE AVERAGING--
1- to 5 -foot
5- to 10 -foot
10- to 20-foot

Model boundary, layer 1
LOCATION OF STREAMFLOW MEASUREMENT-Number is average base-flow reduction, in million gallons per day

1.1 Atreamflow-gaging station

$0.0 \triangle$ Low-flow station

$0.2 \leqslant$ Head of tide

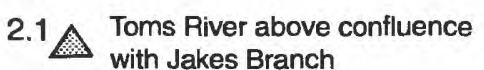

Figure 43. Average water-level declines and base-flow reduction due to projected 2010 withdrawals, Toms River, Metedeconk River, and Kettle Creek Basins, New Jersey. 


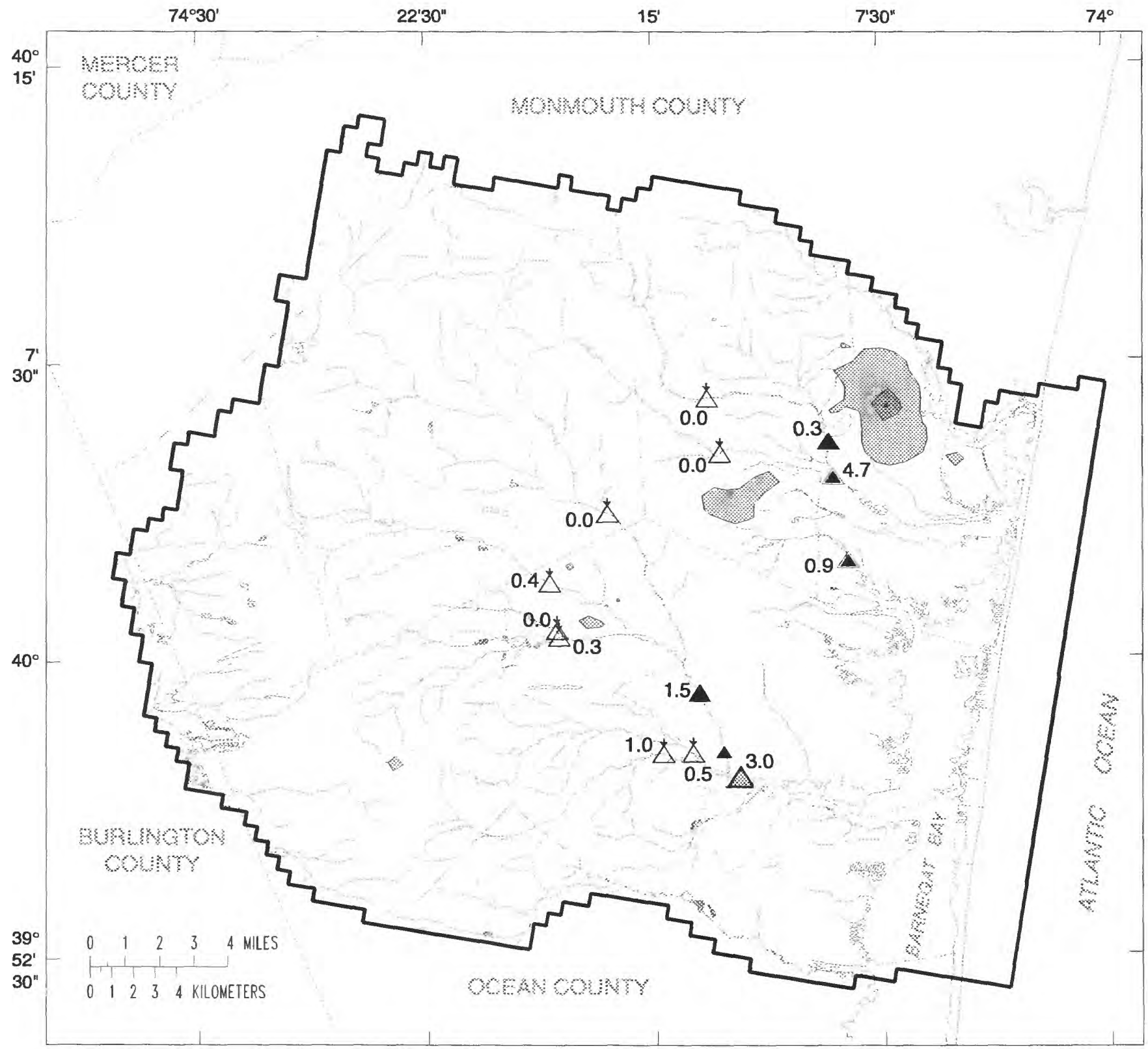

EXPLANATION

AREA OF WATER LEVEL DECLINE AVERAGING--

$$
\begin{aligned}
& 1 \text { - to } 5 \text {-foot } \\
& \text { 5- to } 10 \text {-foot } \\
& 10 \text { - to } 20 \text {-foot }
\end{aligned}
$$

Model boundary, layer 1
LOCATION OF STREAMFLOW MEASUREMENT-Number is average base-flow reduction, in million gallons per day

$$
\begin{aligned}
& 0.3 \triangle \text { Streamflow-gaging station } \\
& 0.0 \triangle \text { Low-flow station } \\
& 0.9 \triangle \text { Head of tide } \\
& 3.0 \text { Toms River above confluence } \\
& \text { with Jakes Branch }
\end{aligned}
$$

Figure 44. Average water-level declines and base-flow reduction due to full-allocation withdrawals, Toms River, Metedeconk River, and Kettle Creek Basins, New Jersey. 
Base-flow reduction under both the 2010 and full-allocation alternatives generally would be less than 3 percent of average recent (1989-92) base flow (table 12). Exceptions for the 2010 alternative are Kettle Creek and Davenport Branch (01408630), where base-flow reduction would be 3.2 and 5.3 percent, respectively. Under the full-allocation alternative, base-flow reduction would be greater than 8 percent of average recent base flow at three stations: Metedeconk River (8.3 percent), Davenport Branch (01408630) (12.2 percent), and Kettle Creek (15.1 percent). Under the 2010 alternative, base-flow reduction at Toms River near Toms River, N.J. (01408500), would be $1.7 \mathrm{ft}^{3} / \mathrm{s}$, or 1.0 percent of average recent base flow, and at North Branch Metedeconk River near Lakewood, N.J. (01408120), reduction would be $0.7 \mathrm{ft}^{3} / \mathrm{s}$, or 1.7 percent of average recent base flow. Under the full-allocation alternative, base-flow reduction at Toms River near Toms River, N.J. (01408500), would be $2.3 \mathrm{ft}^{3} / \mathrm{s}$, or 1.4 percent of average recent base flow, and at North Branch Metedeconk River near Lakewood, N.J. (01408120), reduction would be $0.5 \mathrm{ft}^{3} / \mathrm{s}$, or 1.2 percent of average recent base flow. The simulated decrease in base-flow reduction at the North Branch Metedeconk River near Lakewood, N.J., is a result of 2010 pumpage for some wells in excess of that expected under full-allocation conditions (table 11).

Water budgets for the three major basins in the study area under both the 2010 and the full-allocation alternatives were compiled and compared to average recent (1989-92) conditions (fig. 45). Increased withdrawals under the full-allocation alternative would have a greater effect on the budget than increases under the 2010 alternative. Recharge and ground-water ET remained the same for all three alternatives; upward leakage from underlying aquifers changed little or not at all. Ground-water withdrawals in the three basins were specified for each alternative. Most of the increase in ground-water withdrawals can be accounted for by decreased base flow and increased induced infiltration from surface water, except in the Kettle Creek Basin in the 2010 alternative, where decreased base flow accounts for all of the increase in ground-water withdrawals.

Under the full-allocation alternative, ground-water withdrawals increased most (4.9 Mgal/d) from average recent withdrawals in the Metedeconk River Basin; 77 percent of the increase is supplied by increased infiltration from surface-water sources and 23 percent can be accounted for by decreased base flow. In the Toms River Basin, ground-water withdrawals increased $2.95 \mathrm{Mgal} / \mathrm{d}$. This increase can be accounted for by an increase in induced infiltration from surface-water sources (66 percent), a decrease in base flow (17 percent), and an increase in inflow from other basins (17 percent). In the Kettle Creek Basin, ground-water withdrawals increased 1.l Mgal/d, which can be accounted for by a reduction in base flow (69 percent) and an increase in induced infiltration from surface-water sources ( 27 percent). The remaining 4 percent can be accounted for by increased inflow from the Toms and Metedeconk River Basins and other basins.

\section{Segsonal Conditions}

Results of the simulation of conditions during a typical 12-month cycle under recent (1989-92) pumping conditions were compared with results of simulations that included projected increases in withdrawals. These comparisons provide the basis for monthly estimates of base-flow reduction as a result of additional ground-water withdrawals. 
Table 12. Predicted base-flow reduction under 2010 and full-allocation alternatives, Toms River, Metedeconk River, and Kettle Creek Basins, New Jersey

[ $\mathrm{f}^{3} / \mathrm{s}$, cubic feet per second; $\mathrm{n} / \mathrm{a}$, not applicable; streamflow-gaging-station location shown in fig. 2]

\begin{tabular}{|c|c|c|c|c|c|c|c|c|}
\hline $\begin{array}{l}\text { Streamflow- } \\
\text { gaging- } \\
\text { station } \\
\text { number }\end{array}$ & $\begin{array}{l}\text { Streamflow- } \\
\text { gaging- } \\
\text { station name }\end{array}$ & $\begin{array}{c}\text { Simulated } \\
\text { average } \\
\text { recent } \\
(1989-92) \\
\text { base flow, } \\
\text { in } \mathrm{ft}^{3} / \mathrm{s}\end{array}$ & $\begin{array}{c}\text { Simulated } \\
2010 \\
\text { base } \\
\text { flow, } \\
\text { in } \mathrm{ft}^{3} / \mathrm{s}\end{array}$ & $\begin{array}{l}2010 \\
\text { base- } \\
\text { flow } \\
\text { reduction, } \\
\text { in } \mathrm{f}^{3} / \mathrm{s}\end{array}$ & $\begin{array}{l}2010 \\
\text { base-flow } \\
\text { reduction, } \\
\text { in percent } \\
\text { of average } \\
\text { recent } \\
(1989-92) \\
\text { base flow }\end{array}$ & $\begin{array}{c}\text { Simulated } \\
\text { full- } \\
\text { allocation } \\
\text { base flow, } \\
\text { in } \mathrm{ft}^{3} / \mathrm{s}\end{array}$ & $\begin{array}{l}\text { Full- } \\
\text { allocation } \\
\text { base-flow } \\
\text { reduction, } \\
\text { in } \mathrm{ft}^{3} / \mathrm{s}\end{array}$ & $\begin{array}{c}\text { Full- } \\
\text { allocation } \\
\text { base-flow } \\
\text { reduction, } \\
\text { in percent of } \\
\text { average } \\
\text { recent (1989- } \\
\text { 92) base flow }\end{array}$ \\
\hline 01408100 & $\begin{array}{l}\text { North Branch } \\
\text { Metedeconk River at } \\
\text { Lakewood, N.J. }\end{array}$ & 22.4 & 21.9 & 0.5 & 2.2 & 22.4 & 0 & 0 \\
\hline 01408120 & $\begin{array}{l}\text { North. Branch } \\
\text { Metedeconk River } \\
\text { near Lakewood, N.J. }\end{array}$ & 40.2 & 39.5 & .7 & 1.7 & 39.7 & .5 & 1.2 \\
\hline 01408140 & $\begin{array}{l}\text { South Branch } \\
\text { Metedeconk River at } \\
\text { Lakewood, N.J. }\end{array}$ & 35.4 & 35.4 & 0 & 0 & 35.4 & 0 & 0 \\
\hline $\mathrm{n} / \mathrm{a}$ & $\begin{array}{l}\text { Metedeconk River at } \\
\text { head of tide }\end{array}$ & 87.5 & 86.4 & 1.1 & 1.3 & 80.2 & 7.3 & 8.3 \\
\hline$n / a$ & $\begin{array}{l}\text { Kettle Creek at head } \\
\text { of tide }\end{array}$ & 9.3 & 9.0 & .3 & 3.2 & 7.9 & 1.4 & 15.1 \\
\hline 01408300 & $\begin{array}{l}\text { Toms River at } \\
\text { Whitesville, N.J. }\end{array}$ & 53.7 & 53.7 & 0 & 0 & 53.7 & 0 & 0 \\
\hline 01408440 & $\begin{array}{l}\text { Union Branch at } \\
\text { Lakehurst, N.J. }\end{array}$ & 34.5 & 34.4 & .1 & .3 & 34.1 & .4 & 1.2 \\
\hline 01408460 & $\begin{array}{l}\text { Manapaqua Brook at } \\
\text { Lakehurst, N.J. }\end{array}$ & 7.1 & 7.1 & 0 & 0 & 7.1 & 0 & 0 \\
\hline 01408490 & $\begin{array}{l}\text { Ridgeway Branch } \\
\text { near Lakehurst, N.J. }\end{array}$ & 35.3 & 35.3 & 0 & 0 & 34.7 & .6 & 1.7 \\
\hline 01408500 & $\begin{array}{l}\text { Toms River near } \\
\text { Toms River, N.J. }\end{array}$ & 163.3 & 161.6 & 1.7 & 1.0 & 161.0 & 2.3 & 1.4 \\
\hline 01408600 & Wrangel Brook & 31.7 & 31.2 & .5 & 1.6 & 31.0 & .7 & 2.2 \\
\hline 01408630 & Davenport Branch & 13.1 & 12.4 & .7 & 5.3 & 11.5 & 1.6 & 12.2 \\
\hline $\mathrm{n} / \mathrm{a}$ & $\begin{array}{l}\text { Toms River above } \\
\text { confluence with } \\
\text { Jakes Branch }\end{array}$ & 215.7 & 212.4 & 3.3 & 1.5 & 211.1 & 4.6 & 2.1 \\
\hline
\end{tabular}




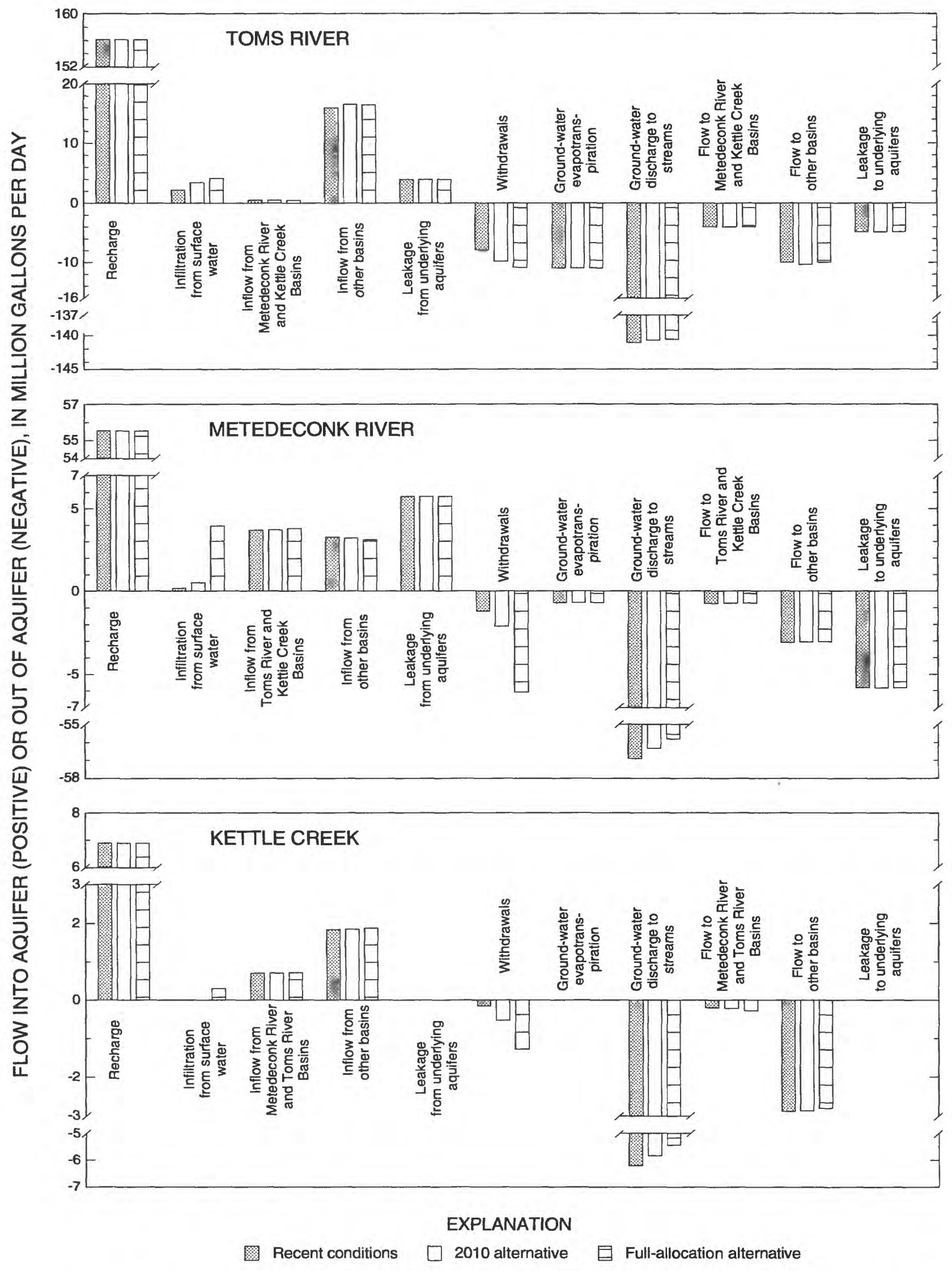

Figure 45. Ground-water budgets for the Toms River, Metedeconk River, and Kettle Creek Basins, New Jersey, under recent conditions, for the projected 2010 alternative and for the full-allocation alternative. 
Increases in ground-water withdrawals can reduce base flows at different rates through the typical seasonal cycle. As described earlier, the rate of reduction is the combined result of two effects: (1) the effect of storage on local hydraulics between the public-supply wells and the affected streams, and (2) the effect of seasonal variations in the withdrawals. As a consequence of the stream/aquifer-system geometry and hydraulic properties of the aquifer system in the study area, and the distances between supply wells and affected streams, the first effect tends to mitigate the second effect. As a result, streams in areas where seasonal variations in withdrawals are relatively moderate exhibit relatively constant rates of base-flow reduction through the annual cycle. Streams in areas where withdrawals are much higher during summer than during winter exhibit more variation in rates of base-flow reduction.

The contrast in reduction patterns among alternatives for all three basins is illustrated in figure 46, which shows simulated monthly base flow under recent conditions and for the two alternatives of increased withdrawals. The differences between the upper curve and the lower two curves shown in figures $46 \mathrm{a}, 46 \mathrm{~b}$, and $46 \mathrm{c}$ represent base-flow reduction of the Toms River, Metedeconk River, and Kettle Creek, respectively, due to increased withdrawals; these values are plotted as separate ordinates in figures 46d, 46e, and 46f. Under the 2010 alternative, reduction of the Toms River remains close to average recent reduction, within the narrow range from 3.0 to $3.5 \mathrm{ft}^{3} / \mathrm{s}$. Reduction of the Metedeconk River and Kettle Creek ranges from 0.8 to $1.7 \mathrm{ft}^{3} / \mathrm{s}$ and 0.23 to $0.38 \mathrm{ft}^{3} / \mathrm{s}$, respectively. A measure of the seasonal variation in reduction is the ratio of maximum to minimum monthly reduction. For this example (2010 alternative), the ratio is 1.16 for the Toms River, 2.13 for the Metedeconk River, and 1.65 for Kettle Creek. An important measure of the severity of base-flow reduction is the amount by which monthly base flow is reduced, expressed as a percentage of base flow normally occurring during that month. By this measure, the maximum base-flow reduction of the Toms River in 2010 would be 2.1 percent during July-October, the maximum for the Metedeconk River would be 1.9 percent during MayJune, and the maximum for Kettle Creek would be 5.7 percent during October.

Under the full-allocation alternative, reduction of the Toms River would remain within the relatively narrow range from 4.2 to $5.0 \mathrm{ft}^{3} / \mathrm{s}$ (1.19 maximum/minimum ratio), whereas the corresponding reduction of the Metedeconk River would be nearly twice as high in July $\left(10.3 \mathrm{ft}^{3} / \mathrm{s}\right)$ as in December $\left(5.2 \mathrm{ft}^{3} / \mathrm{s} ; 1.98\right.$ maximum/minimum ratio). This contrast between the two streams in monthly base-flow reduction under full allocation is explained by two contributing factors: (1) seasonal variations in projected withdrawais in the area contributing base flow to the Metedeconk River are larger than those in the area contributing base flow to the Toms River, and (2) the projected increase in withdrawals in the area contributing base flow to the Metedeconk River is located near the river, so that the lagtime between increased withdrawals and increased reduction would be short. Base-flow reduction of Kettle Creek would range from 0.91 to $1.89 \mathrm{ft}^{3}$ / $\mathrm{s}$, with a maximum/minimum ratio of 2.08 . The maximum base-flow reduction as a percentage of recent monthly base flow of the Toms River would be 3 percent in June-October, the maximum for the Metedeconk River would be 14.3 percent in July, and the maximum for Kettle Creek would be 26.5 percent in October. 

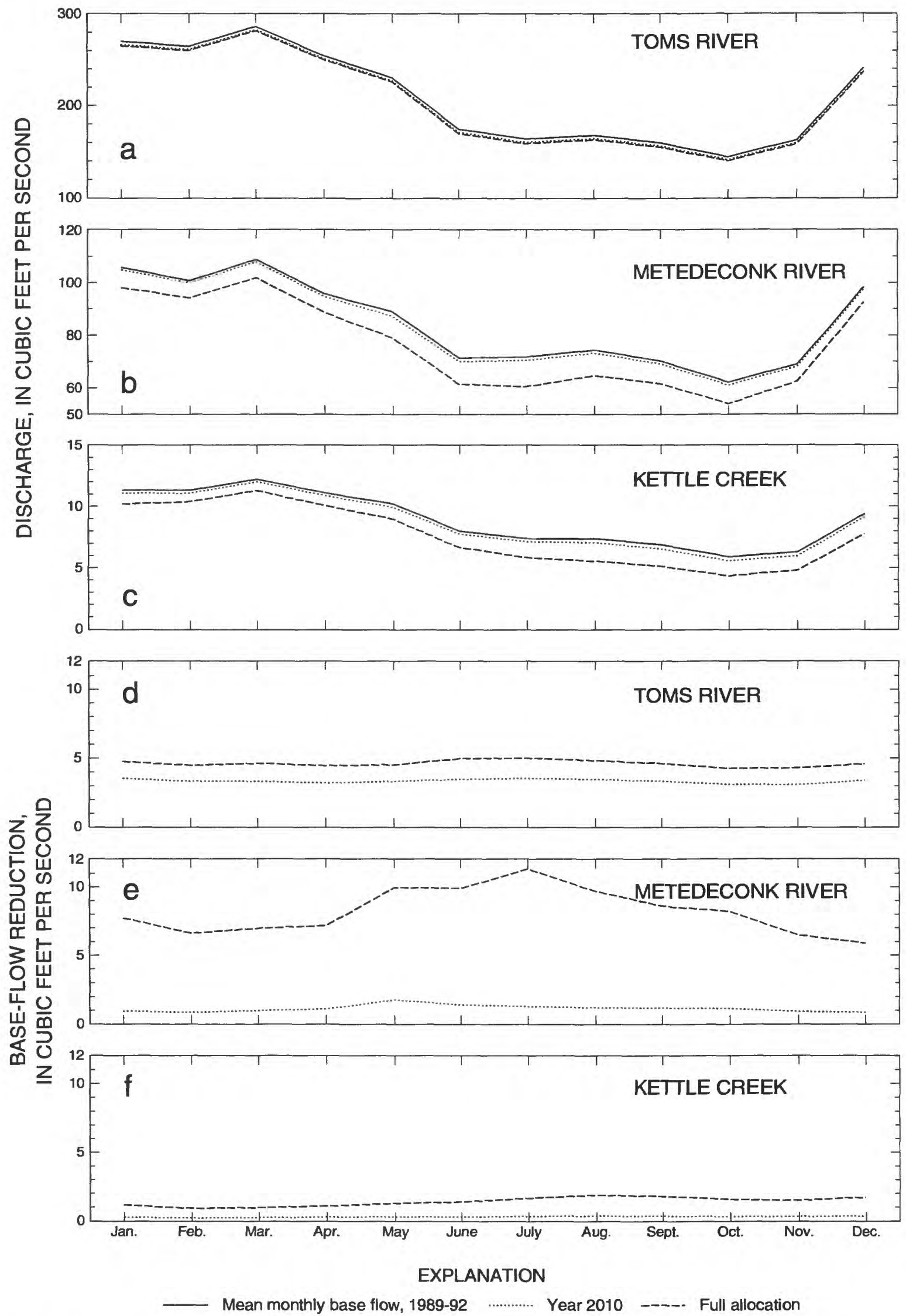

Figure 46. Simulated mean monthly base flow for the projected 2010 and full-allocation alternatives for (a) the Toms River, (b) the Metedeconk River, and (c) Kettle Creek, and mean monthly base-flow reduction during 1989-92 for (d) the Toms River, (e) the Metedeconk River, and (f) Kettle Creek, New Jersey. 


\section{SUMMARY AND CONCLUSIONS}

The unconfined Kirkwood-Cohansey aquifer system is a major source of water supply for coastal communities in Ocean and Monmouth Counties, New Jersey. Ground-water withdrawals from the aquifer system and reduced recharge in urban areas have resulted in water-level declines and a reduction in fresh-ground-water discharge to streams, wetlands, Barnegat Bay, the associated estuaries, and the ocean. The USGS, in cooperation with the NJDEP, conducted a study to address concerns about possible hydrologic effects of additional ground-water withdrawals. The study included an analysis of ground-water flow in the aquifer system and its interactions with surface water conducted by using steady-state and transient three-dimensional models. The models were used to estimate average and seasonal hydrologic effects of projected increases in withdrawals.

The Kirkwood-Cohansey aquifer system in the study area is a southeastward-dipping wedge of unconsolidated materials that include gravel, sand, silt, and clay. The aquifer system is well-connected with the underlying Vincentown aquifer in updip areas where the intervening confining unit is thin or absent. Some water flows between the Kirkwood-Cohansey aquifer system and the underlying Piney Point aquifer near the coast. The shallow part of the flow system is presumed to be bounded by salty water beneath Barnegat Bay and the ocean. In the deep part of the flow system, freshwater probably extends offshore. The estimated hydraulic conductivity of the Cohansey Sand is higher than that of the sandy part of the Kirkwood Formation.

Recharge to the aquifer system is higher in areas where the relatively coarse Cohansey Sand crops out than in areas where the finer, sandy sediments of the Kirkwood Formation crop out. Recharge in urban areas has been reduced by an estimated 20 percent. Recharge is typically highest during winter months when evapotranspiration (ET) is low and lowest during summer months when ET is high. Streams and other surface-water features generally are in good hydraulic connection with the aquifer system, and streams generally gain flow throughout the year.

Withdrawals from the Kirkwood-Cohansey aquifer system in the study area averaged about $15.5 \mathrm{Mgal} / \mathrm{d}$ during 1989-92. Average monthly withdrawals were highest (20.0 Mgal/d) during July. Average withdrawals are projected to increase by about 27 percent to about 19.8 $\mathrm{Mgal} / \mathrm{d}$ by the year 2010 , with peak monthly withdrawals of about $26.3 \mathrm{Mgal} / \mathrm{d}$. Average withdrawals expected under conditions of full utilization of present allocations would exceed 1989-92 withdrawals by 65 percent, totaling $25.6 \mathrm{Mgal} / \mathrm{d}$; peak monthly withdrawals would reach about 34.7 Mgal/d. These withdrawals are 100-percent consumptive; most of the study-area population is served by a regional sewage-collection system with ocean outfall.

Simulated average water levels, gradients, and base flows were consistent with those observed in the field. Transient simulations of June 1992-May 1993 water levels and base flows agreed closely with those observed in the field during that period. Transient simulations of a typical annual cycle of flow under predevelopment conditions demonstrate the effect of aquifer storage in delaying seasonally high and low ground-water levels following respective periods of high and low recharge.

The effects of recent and projected ground-water withdrawals on water levels, flow patterns, stream base flows, and water budgets were estimated. Simulation results indicate that historical withdrawals have lowered water levels from predevelopment positions by as much as 
about $20 \mathrm{ft}$ near pumping centers. Projected increases in withdrawals under conditions of full utilization of present allocations would result in additional declines of up to about $20 \mathrm{ft}$ in some areas. Increases in withdrawals projected to the year 2010 would result in smaller water-level declines. Sensitivity tests showed that the estimated areal extent of drawdown is sensitive to values of streambed conductance, hydraulic conductivity, and recharge, and that estimated baseflow reduction is sensitive to values of hydraulic conductivity and recharge. Although alternative models in which different combinations of values of these parameters are used could result in substantially different estimates of water-level changes and base-flow reduction, the calibrated model is constrained by a substantial data base and results are considered reasonably accurate.

Historical withdrawals have resulted in average base-flow reduction of up to about 12 percent of predevelopment base flow in some streams. Projected withdrawals at full allocation would further reduce the average base flow of the Toms River, the Metedeconk River, and Kettle Creek by about 2,8 , and 15 percent, respectively. Seasonal variations in base-flow reduction are controlled by seasonal variations in withdrawal rates and by aquifer-storage effects. At full allocation, maximum additional base-flow reduction of the Toms River, the Metedeconk River, and Kettle Creek would be about 3, 14, and 26 percent, respectively. Increases in withdrawals projected to the year 2010 would result in smaller reductions in base flow. 


\section{SELECTED REFERENCES}

Alley, W. M., 1984, On the treatment of evapotranspiration, soil moisture accounting, and aquifer recharge in monthly water balance models: Water Resources Research, v. 20, no. 8, p. 1137-1149.

Anderson, H.R., and Appel, C.A., 1969, Geology and ground-water resources of Ocean County, New Jersey: New Jersey Department of Conservation and Economic Development Special Report no. 29, 93 p.

Bouwer, Herman, 1978, Groundwater hydrology: New York, McGraw-Hill, Inc., 480 p.

Brown, G.A., and Zapecza, O.S., 1990, Results of test drilling in Howell Township, Monmouth County, New Jersey: U.S. Geological Survey Water-Resources Investigations Report 90-4062, 42 p.

Camp Dresser and Mckee, Inc., 1988, Ground-water modeling of the Ciba-Geigy Plant in Toms River, New Jersey: Unpublished consultant's report, New York, March 1988.

$\mathrm{CH}_{2} \mathrm{M}$ Hill, Metcalf and Eddy, Inc., and New Jersey First, Inc., 1993, New Jersey statewide water supply master plan: Prepared for the New Jersey Department of Environmental Protection and Energy, 10 volumes revised periodically on a rotating basis.

Daniel, J.F., 1976, Estimating ground water evapotranspiration from streamflow records: Water Resources Research, v. 12, no. 3, p. 360-364.

Harbaugh, A.W., and Tilley, C.L., 1984, Steady-state computer model of the water-table aquifer in the Mullica River Basin, the Pine Barrens, New Jersey: U.S. Geological Survey WaterResources Investigations Report 84-4295, 38 p.

Horton, R.E., 1935, Surface runoff phenomena, part 1, Analysis of the hydrograph: Vorheesville, N.Y., Horton Hydrologic Laboratory Publication 101, 73 p.

Jablonski, L.A., 1968, Ground-water resources of Monmouth County, New Jersey: New Jersey Department of Conservation and Economic Development Special Report no. 23, 117 p.

Jenkins, C.T., 1968, Computation of rate and volume of stream depletion by wells:

U.S. Geological Survey Techniques of Water-Resources Investigations, book 4, chap. D1, $17 \mathrm{p}$.

Koury, M.A., Simons, H.A., and Scarrow, J.W., 1989, Modeling aquifer mounding beneath the Manasquan Reservoir, in Solving ground water problems with models: Proceedings of the fourth international conference on the use of models to analyze and find working solutions to ground water problems, Indianapolis, Ind., February 7-9, 1989: International Ground Water Modeling Center, Indianapolis, Ind., p. 715-734. 


\section{SELECTED REFERENCES--Continued}

Ku, H.F.H., Hagelin, N.W., and Buxton, H.T., 1992, Effects of urban storm-runoff on groundwater recharge in Nassau County, New York: Ground Water, v. 30, no. 4, p. 507-514.

Lang, S.M., and Rhodehamel, E.C., 1963, Aquifer test at a site on the Mullica River in the Wharton Tract, southern New Jersey: International Association of Scientific Hydrology Bulletin, v. 8, no. 2, p. 31-38.

Martin, Mary, in press, Ground-water flow in the New Jersey Coastal Plain: U.S. Geological Survey Professional Paper 1404-H.

McDonald, M.G., and Harbaugh, A.W., 1988, A modular three-dimensional finite-difference ground-water flow model: U.S. Geological Survey Techniques of Water-Resources Investigations, book 6, chap. A1, $586 \mathrm{p}$.

Modica, Edward, 1996, Simulated effects of development on ground-water flow patterns in areas adjacent to major stream divides, New Jersey Pinelands: U.S. Geological Survey WaterResources Investigations Report 95-4133, 46 p.

New Jersey Department of Environmental Protection, 1986, Procedures for implementation of water supply critical area no. 1: New Jersey Department of Environmental Protection, Division of Water Resources, Trenton, New Jersey, September 1986, 8 p.

NUS Corporation, 1988, Remedial investigation for the Ciba-Geigy site, Toms River, Dover Township, Ocean County, New Jersey: Unpublished consultant's report, January 22, 1988.

Pollock, D.W., 1989, Documentation of computer programs to compute and display pathlines using results from the U.S. Geological Survey modular three-dimensional finite-difference ground-water flow model: U.S. Geological Survey Open-File Report 89-381, 188 p.

Pollock, D.W., 1994, User's guide for MODPATH/MODPATH-PLOT, Version 3: A particle tracking post-processing package for MODFLOW, the U.S. Geological Survey finitedifference ground-water flow model: U.S. Geological Survey Open-File Report 94-464, $234 \mathrm{p}$.

Reilly, T.E., and Buxton, H.T., 1985, Effects of sanitary sewering on ground-water levels and streams in Nassau and Suffolk Counties, New York, Part 3: Development and application of southern Nassau County model: U.S. Geological Survey Water-Resources Investigations Report 83-4210, 41 p.

Rhodehamel, E.C., 1970, A hydrologic analysis of the New Jersey Pine Barrens region: U.S. Geological Survey Water-Resources Investigations Circular 22, 35 p.

1973, Geology and water resources of the Wharton Tract and the Mullica River Basin in southern New Jersey: New Jersey Department of Environmental Protection Special Report 36, 58 p. 


\section{SELECTED REFERENCES--Continued}

1979, Geology of the Pine Barrens of New Jersey, in Forman, R.T.T., ed., Pine Barrens: Ecosystem and landscape: New York, Academic Press, p. 39-60.

Rorabaugh, M.I., 1960, Use of water levels in estimating aquifer constants in a finite aquifer: International Association of Scientific Hydrology Commission of Subterranean Waters, Publication no. 52, p. 314-323.

1964, Estimating changes in bank storage and ground-water contribution to streamflow: International Association of Scientific Hydrology, Publication 63, p. 432-441.

Rush, E.F., 1968, Geology and ground-water resources of Burlington County, New Jersey: New Jersey Department of Conservation and Economic Development Special Report no. 26, $65 \mathrm{p}$.

Rutledge, A.T., 1992, Methods of using streamflow records for estimating total and effective recharge in the Appalachian Valley and Ridge, Piedmont, and Blue Ridge physiographic provinces, in Hotchkiss, W.R., and Johnson, A.I., eds., Regional aquifer systems of the United States: Aquifers of the Southern and Eastern States: American Water Resources Association Monograph Series 17, p. 59-73.

Rutledge, A.T., 1993, Computer programs for describing the recession of ground-water discharge and for estimating mean ground-water recharge and discharge from streamflow records: U.S. Geological Survey Water-Resources Investigations Report 93-4121, 45 p.

Rutledge, A.T., and Daniel, C.C., III, 1994, Testing an automated method to estimate groundwater recharge from streamflow records: Groundwater, v. 32, no. 2, p. 180-189.

Seaber, P.R., 1963, Chloride concentrations of water from wells in the Atlantic Coastal Plain of New Jersey, 1923-61: New Jersey Department of Conservation and Economic Development Special Report no. 29, 250 p.

Sloto, R.A., and Crouse, M.Y., 1996, HYSEP: A computer program for streamflow-hydrograph separation and analysis: U.S. Geological Survey Water-Resources Investigations Report 96-4040, 46 p.

Sugarman, P.J., Owens, J.P., and Bybell, L.M., 1991, Geologic map of the Adelphia and Farmingdale quadrangles, Monmouth and Ocean Counties, New Jersey: New Jersey Geological Survey Geologic Map Series 91-1, 1 pl., scale 1:24,000.

U.S. Geological Survey, 1986, Land-use and land-cover digital data from 1:250,000- and 1:100,000-scale maps: Data user's guide \#4: National Mapping Program Technical Instructions, Reston, Va., 36 p.

Walton, W. C., 1970, Groundwater resource evaluation, New York, Mcgraw-Hill, Inc., 664 p. 


\section{SELECTED REFERENCES-Continued}

Watt, M.K., Johnson, M.L., and Lacombe, P.J., 1994, Hydrology of the unconfined aquifer system, Toms River, Metedeconk River, and Kettle Creek Basins, New Jersey, 1987-90: U.S. Geological Survey Water-Resources Investigations Report 93-4110, 5 sheets.

Zapecza, O.S., 1989, Hydrogeologic framework of the New Jersey Coastal Plain: U.S. Geological Survey Professional Paper 1404-B, 49 p., 24 pl.

Zapecza, O.S., Voronin, L.M., and Martin, Mary, 1987, Ground-water-withdrawal and water-level data used to simulate regional flow in the major Coastal Plain aquifers of New Jersey: U.S. Geological Survey Water-Resources Investigations Report 87-4038, 119 p. 


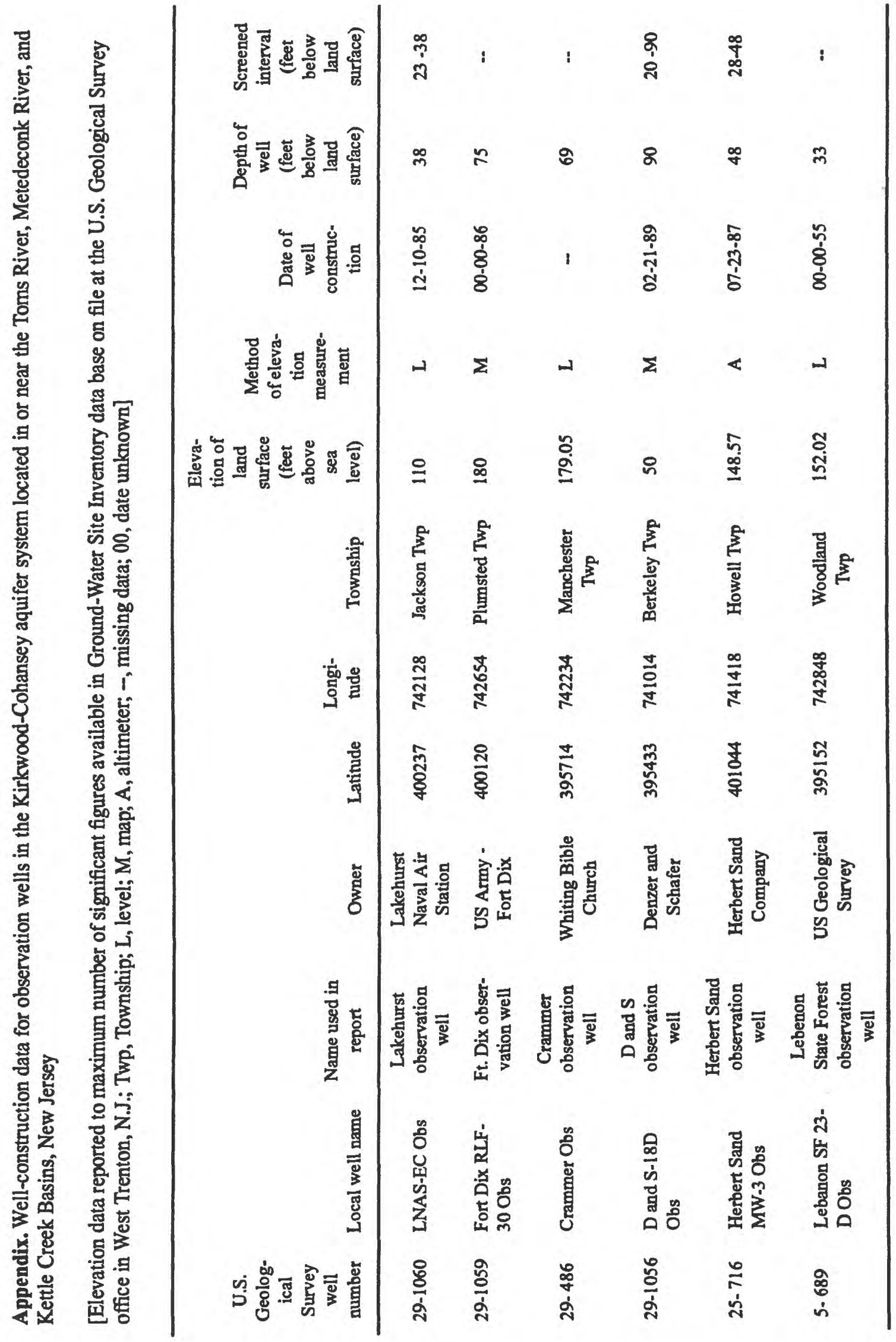

